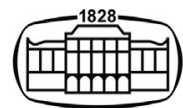

AKADÉMIAI KIADÓ

European Journal of Microbiology and Immunology

10 (2020) 2, 29-63

DOl:

$10.1556 / 1886.2020 .00008$

(c) 2020 The Authors

\section{REVIEW PAPER}

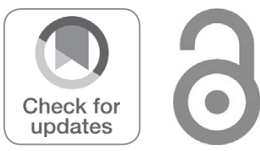

*Corresponding author. Department of Microbiology and Hospital Hygiene, Bundeswehr Hospital of Hamburg, Bernhard Nocht Street 74, Hamburg, D-20359, Germany.

Tel.: +49406947 28743; fax: +49 40694728709.

E-mail: Frickmann@bni-hamburg.de

\title{
Review: The risk of contracting anthrax from spore-contaminated soil - A military medical perspective
}

\author{
ERNST-JÜRGEN FINKE ${ }^{1}$, WOLFGANG BEYER ${ }^{2}$, \\ ULRIKE LODERSTÄDT $^{3}$ and HAGEN FRICKMANN ${ }^{4,5 *}$ ๑
}

\footnotetext{
${ }^{1}$ Retired, Dresden, Germany

${ }^{2}$ Department of Infectiology and Animal Hygiene, University of Hohenheim, Institute of Animal Science, Stuttgart, Germany

${ }^{3}$ Diagnostic Department, Bernhard-Nocht-Institute for Tropical Medicine Hamburg, Hamburg, Germany

${ }^{4}$ Department of Microbiology and Hospital Hygiene, Bundeswehr Hospital Hamburg, Hamburg, Germany

${ }^{5}$ Institute for Medical Microbiology, Virology and Hygiene, University Medicine Rostock, Rostock, Germany
}

Received: March 21, 2020 • Accepted: April 10, 2020

Published online: June 5,2020

\begin{abstract}
Anthrax is an infectious disease of relevance for military forces. Although spores of Bacillus anthracis obiquitously occur in soil, reports on soil-borne transmission to humans are scarce. In this narrative review, the potential of soil-borne transmission of anthrax to humans is discussed based on pathogen-specific characteristics and reports on anthrax in the course of several centuries of warfare. In theory, anthrax foci can pose a potential risk of infection to animals and humans if sufficient amounts of virulent spores are present in the soil even after an extended period of time. In praxis, however, transmissions are usually due to contacts with animal products and reported events of soil-based transmissions are scarce. In the history of warfare, even in the trenches of World War I, reported anthrax cases due to soil-contaminated wounds are virtually absent. Both the perspectives and the experience of the Western hemisphere and of former Soviet Republics are presented. Based on the accessible data as provided in the review, the transmission risk of anthrax by infections of wounds due to spore-contaminated soil is considered as very low under the most circumstance. Active historic anthrax foci may, however, still pose a risk to the health of deployed soldiers.
\end{abstract}

\section{KEYWORDS}

bacillus anthracis, anthrax, soil, transmission, soldier, risk assessment, spore

\section{INTRODUCTION}

\section{Epidemiology in a nutshell}

Anthrax is an acute bacterial zoonosis of mainly wild and domestic herbivores (e.g. cattle, sheep, goats, donkeys, horses, reindeer, antelopes and camels) although any warm blooded animal might circumstantially get infected. It is caused by Bacillus (B.) anthracis and is occasionally transmitted to humans [1-2]. Humans might get affected by activities such as hunting, breeding and occupational or nutritional exposure to contaminated animal products (Fig. 1). Ecological, social, cultural, political and economic factors continue to influence this process, generating and shaping nosoareals of anthrax worldwide [3-5]. Anthrax is endemic in some countries in Asia, Africa, the Americas, and southern Europe. World Health Organization (WHO) [6] estimates that the worldwide annual occurrence of anthrax is less than 100,000 cases. There are, however, likely a large number of additional cases due to unreported outbreaks. 


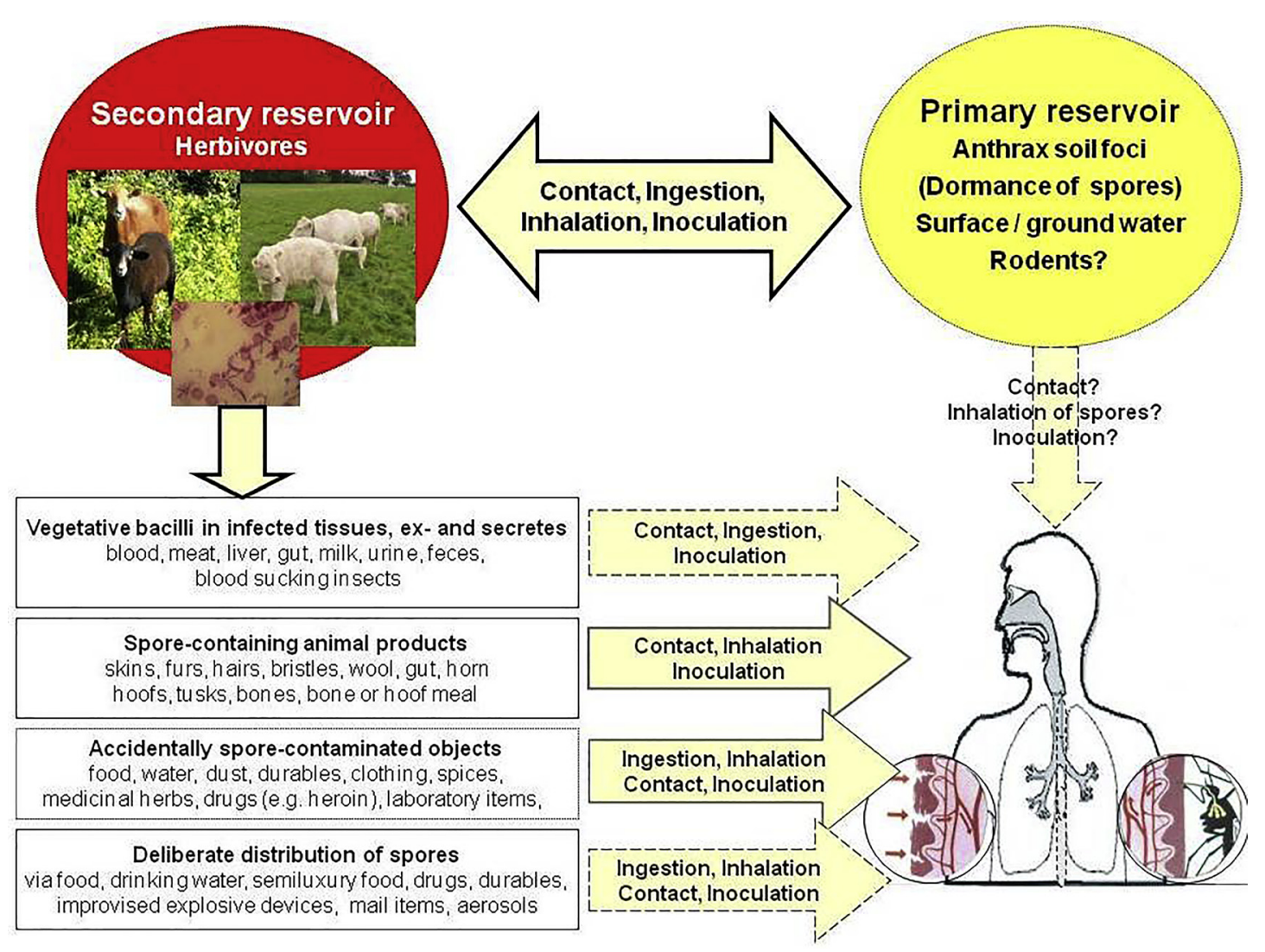

Fig. 1. Key features of the epidemic process of anthrax and possible routes of transmission on military personnel in endemic areas [6, 7, 27, $28,31,36,38,41,43,56,57,59-61,87,88,173,209,275$ ]

\section{The pathogen and molecular mechanisms of pathogenicity}

The causative agent is a Gram-positive, non-motile, encapsulated, facultatively anaerobic, endospore forming bacterium, which is approximately $0.8-1.2 \mu \mathrm{m}$ by $3-5(10) \mu \mathrm{m}$ in size [7]. Like all Bacillus species, B. anthracis forms spores that are commonly found in the soil. Unlike other species in this genus, it is the only obligate pathogenic Bacillus of mammals [8]. Phylogenetically, there are three main lineages (A, B, and C clades) of B. anthracis [9]. The A clade is the most important, globally dispersed causative form of anthrax ( $>90 \%$ of all cases) [9]. Modern whole genome sequence single nucleotide polymorphism- (SNP-)analyses and the definition of derived canonical SNPs (canSNPs) are used to further subdivide these main clades into phylogeographical sub-branches [10-14].

The virulence of $B$. anthracis is based on an antiphagocytic poly-gamma-D-glutamic acid capsule, an exotoxin complex (lethal toxin and oedema toxin), and exoproteases that can lyse macrophages and release interleukin-1 (IL-1) and tumour necrosis factor (TNF) [15].

The anthrax toxin complex consists of three components, i.e. protective antigen (PA), lethal factor (LF), which is a zinc protease [16-18], and oedema factor (EF), which is an adenylate cyclase $[19,20]$. PA is a pore-forming protein that complexes with LF or EF. After binding to cellular receptors, PA mediates the entry of LF or EF into mammalian cells
[15]. The anthrax toxins exhibit immunosuppressive and cytotoxic properties that enable the micro-organism to grow and spread unimpeded in a host [21,22]. The so-called pXO2 plasmid contains the genes that encode for the capsule, which confers resistance to phagocytosis, and the pXO1 plasmid carries the genes for anthrax toxins $[6,20,23$, 24]. The loss of one or both plasmids leads to a decrease in virulence [4, 25-27]. This occurs in a small part of bacteria in released blood prior or during the sporulation.

\section{Sporulation as a survival strategy}

Vegetative B. anthracis in unopened carcasses are destroyed by putrefactive bacteria. After release to the environment they may become rapidly destroyed by exposure to ultraviolet light, low humidity, high temperature and by competing soil and water micro-organisms [6, 28, 29]. They are, however, able to replicate for some time in soil where blood has spilt [6]. Once released and under appropriate conditions [30], B. anthracis forms endospores (sporulation) in response to various stress factors such as the absence of adequate nutrients. These endospores are infectious, dormant and highly tenacious forms of the bacterium [31, 32]. Spores are $1 \mu \mathrm{m}$ by $3 \mu \mathrm{m}$ in size and consist of a core, which contains the DNA, and three concentric layers (cortex, coat and exosporium) [32] which protect them from environmental effects. Following infection of a susceptible host, the spores germinate in the presence of cellular 
germinants (e.g. amino acids, ribonucleotides) and develop into new vegetative bacterial cells [32]. These cells initially grow and multiply at the point of entry or in lymphatic tissues. Then they spread throughout the body via the lympho-haematogenous route and cause haemorrhagic necrotic lesions, toxaemia and septicaemia [33, 34].

\section{Mode of infection in animals}

Domestic animals (Fig. 1) usually become infected through the ingestion of anthrax spores (grass, soil or water) while grazing or browsing $[7,28,31]$. Horseflies (and other tabanids) and mosquitoes, too, can transfer B. anthracis of infected animals in their final stage of the disease or through spore-contaminated water [7, 27, 35, 36, 37].

Sheep and pigs might have been infected via inhalation of spore-containing dust [28, 31, 38-40].

In highly susceptible animals (e.g. sheep and goats), anthrax progresses as a peracute haemorrhagic infection leading to death. In the final stage of the disease, large amounts of anthrax bacilli are released in bloody exudates from all body orifices [7, 25, 28, 41, 42]. In these cases and when animal carcasses decompose or are opened by scavengers, anthrax bacilli are exposed to the outside environment (pastures, water) and sporulation commences again [7, 25, 28, 43-45].

\section{Persistence of anthrax spores in the environment}

Anthrax spores are relatively resistant to heat, desiccation and certain disinfectants. Depending on the type and nature of contaminated material and the biotic and abiotic characteristics of the outside environment, they can thus survive for decades not only in soil, surface waters and mud but also in or on skins, hides, fur, wool, hair, bristles, hooves, horns or bones from diseased animals, in wastewater and sludge from tanneries, or on surfaces such as wood and metal [7, 21, 27, 28, 41, 43, 46-52].

Viable spores were present in 200 -year-old bones that were retrieved during archaeological excavations at a site in the Kruger National Park [53]. B. anthracis was isolated from dried soil that had been stored for sixty years [54].

Infective spores that lie dormant in environmental habitats ensure the survival of $B$. anthracis in nature in anthrax soil foci or nosoareas where animals can become infected while grazing [3, 5, 55-57]. Since the soil is the most important reservoir of $B$. anthracis, anthrax was previously referred to as a soil-borne infection [58]. The transmission of organisms from and to different living and non-living reservoirs, e.g. soil, herbivores and (possibly) rodents [59], maintains the epizootic cycle of anthrax even after an extended latency period (Fig. 1).

\section{Transmission to humans}

Epidemiologically, anthrax in humans can result from occupational (agricultural or industrial) exposure and nonoccupational (accidental or everyday) exposure (Table 1) [38, 60-62]. Animal graves and burial sites, biothermal pits and other places for the disposal of animals that died of anthrax are referred to as anthrax (soil) foci, anthrax districts or permanent anthrax foci [28, 61, 63, 64]. In Russia and some former Soviet republics, inhabited areas, including livestock farms, pastures or natural areas, where an epizootic anthrax focus was found (regardless of the time of occurrence) are termed "stationary unfavourable by anthrax sites" (SUS) or "stationary anthrax-affected areas" (SAA) [64, 65].

The vegetative forms of $B$. anthracis can be transmitted by direct contact with bloody discharges or with the body and organs of animals that died of anthrax [4, 6, 7, 28]. Indirect transmission of the spore form of $B$. anthracis, however, plays a far more important role. Humans become infected during occupational or private activities involving contact with infected carcasses as well as raw, semi-finished and finished products and through exposure to sporecontaminated objects (Table 1).

In Germany between 1910 and 1957, human anthrax occurred during forced slaughter in $30-50 \%$ of cases by contact with furs, hides and skins in $12-31 \%$, with animal hairs and brushes in $8-24 \%$, with carcasses of sick animals in $4-14 \%$, and with sick animals in less than $5 \%$ of cases [60]. Other professional exposure caused infection in $2-8 \%$ of patients and $4-29 \%$ of them had no professional history or it could not be clarified.

Anthrax outbreaks can also be caused by laboratory accidents or as a result of the accidental release of anthrax spores from laboratories and production facilities (e.g. the Sverdlovsk incident in 1979) or as a result of the deliberate spread of an anthrax aerosol that can penetrate deeply into the lungs (e.g. the letter attacks in the United States in 2001) [28, 64, 66-68].

Non-occupational exposures to $B$. anthracis, e.g. to spore-containing drugs or articles of daily use that are made of raw animal materials from endemic countries (goat skin, horse hair, bristles or tusk) such as leather goods and toys, bongo drums, rugs, toy animals, or shaving brushes (Table 1$)$, are relatively rare $[28,69-73]$.

\section{Clinical manifestations}

Clinical manifestations of anthrax depend on the portal of entry to the body (skin, respiratory tract or gastrointestinal system). The illness then takes either the cutaneous, inhalational or intestinal form [6, 44, 6174,75$]$.

Cutaneous anthrax. Cutaneous anthrax accounts for approximately $90-95 \%$ of all cases. Infection usually occurs through small lesions (abrasions, cuts, fissures) on exposed skin surfaces $[6,28,38,44,61,76]$.

The organisms are transmitted either directly by contact (killing, slaughtering) with diseased or dead animals, their discharges, blood, meat, milk or internal organs or indirectly through processing, storing or transporting infected animal products and objects contaminated with spores [6, 28, 64]. Infections can also occur as a result of bites of blood-feeding insects $[35,36,64]$. Biting flies can cause $1-12 \%$ of infections during epizootic periods $[38,77]$. In former times, anthrax 
Table 1. Overview on possible sources of human anthrax $[6,7,28,38,41,44,60,61,62,66,72,87,88,94,95,97,107,111,184,223,224,234,236,275,277,353-355]$

\begin{tabular}{|c|c|c|c|c|c|}
\hline \multicolumn{2}{|l|}{ Industry/critical items } & \multicolumn{2}{|c|}{ Agriculture and horticulture } & \multicolumn{2}{|c|}{ other } \\
\hline Tannery & raw leather, waste water & Milk and meat stockbreeder & Sick or death animals & Waste water treatment & Waste water sludge \\
\hline Leather manufacture & Leather goods & cattle dealer shepherd farmer & contaminated animal food, & & \\
\hline Brush factory & Brushes, shaving brushes & & grass, water sources (e.g. dwells) & Carriers & Bags containers \\
\hline $\begin{array}{l}\text { Wool combing } \\
\text { factory }\end{array}$ & Wool, wool yarn (Garn) & & & & \\
\hline $\begin{array}{l}\text { Woolen blanket } \\
\text { factory }\end{array}$ & Woolen blanket & Market garden Gardener & $\begin{array}{l}\text { Contaminated fertilizers: animal } \\
\text { bone meal hoof meal }\end{array}$ & $\begin{array}{l}\text { Building trade roadworks, civil } \\
\text { engineering channel workers }\end{array}$ & $\begin{array}{l}\text { Soil surface and ground water in } \\
\text { arthrax districts }\end{array}$ \\
\hline Hair yarnspin factory & Animal air yarn (garn) & & & & \\
\hline $\begin{array}{l}\text { Glue and soap } \\
\text { boiling }\end{array}$ & Glues, soups & & & & \\
\hline $\begin{array}{l}\text { Fertilizer \& horn } \\
\text { factory }\end{array}$ & $\begin{array}{l}\text { Bone-roof meal, horn } \\
\text { goods }\end{array}$ & $\begin{array}{c}\text { Veterinary surgeon keeper in } \\
\text { Zooparks }\end{array}$ & $\begin{array}{l}\text { Sick or death animals infectious } \\
\text { tissues, secreates, excetes, }\end{array}$ & & \\
\hline Hide and fur trade & Hides and fur & & contaminated items and & Diagnostic \& Research & Diagnostic specimens animals \\
\hline $\begin{array}{l}\text { Carpet \& fur } \\
\text { manufactory }\end{array}$ & FUR good, carpet (Wool) & & environmental objects & $\begin{array}{c}\text { Laboratories (medical, } \\
\text { veterinarian pharmaceutical) }\end{array}$ & $\begin{array}{l}\text { laboratory equipment Aerosols } \\
\text { Contaminated items (e.g. food, }\end{array}$ \\
\hline Catgut manufactory & Catgut (animal gut!) & Abbatoirs & Death animals infectious tissues, & Bioweapon’s facilities & drugs, water) \\
\hline $\begin{array}{l}\text { Instrument } \\
\text { manufactory }\end{array}$ & $\begin{array}{l}\text { Piano (ivory), bongo } \\
\text { drums }\end{array}$ & & $\begin{array}{l}\text { secreates,excetes, contaminated } \\
\text { items and environmental (soil, }\end{array}$ & & \\
\hline Meat instrument & Meat, meat product & & water) & & \\
\hline Slaughter house & $\begin{array}{l}\text { Meat, innards, bones, } \\
\text { horn, hoof }\end{array}$ & Butchers & Infectious meat, innards, bones & Postfacilities & Mail transportbag \\
\hline Animal food factory & Meat and bone meal & & & Soldiers travellers & $\begin{array}{c}\text { Shaving brushes fur goods, soap, } \\
\text { drums }\end{array}$ \\
\hline
\end{tabular}




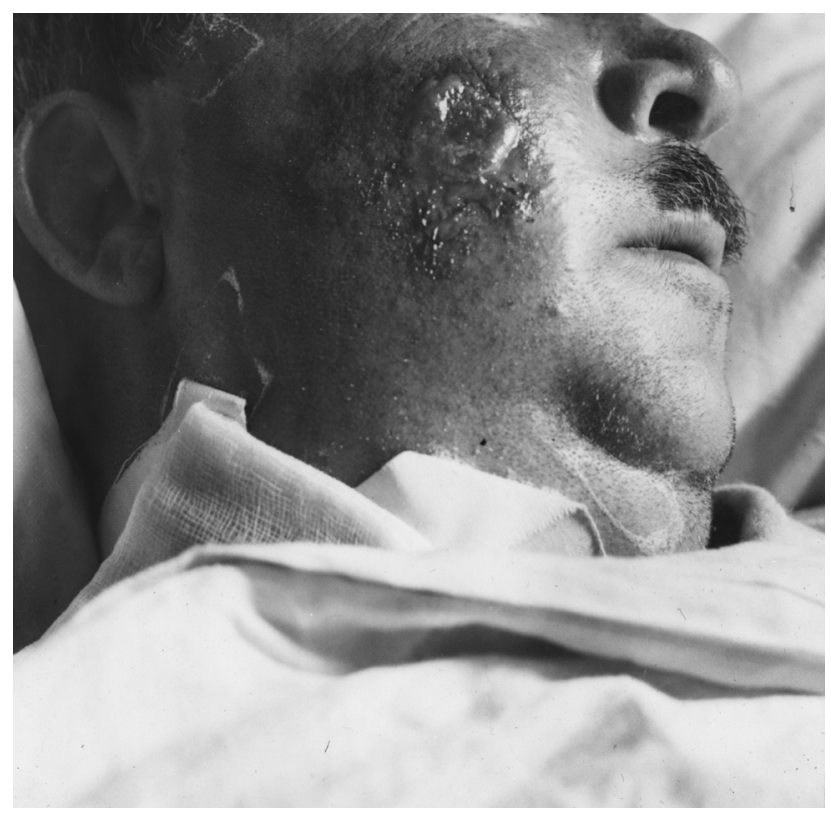

Fig. 2. A soldier presenting with cutaneous anthrax. Source: Photograph (repro): Military Pathology Collection of the Military Medical Academy, Berlin (Kriegspathologische Sammlung der Militärärztlichen Akademie Berlin), 1945, missing. German Armed Forces Medical Academy, Military History Collection (Sanitätsakademie der Bundeswehr, Militärgeschichtliche Lehrsammlung), no signature

infections of the face and neck often occurred in wool mill workers who had processed infected animal wool and touched their face or neck with contaminated fingers [37, 38 ] reported that in case of a bite 10 spores constitute the subcutaneous dose of infection.

The rare possibility of an infection through contact with spore-containing soil is discussed later.

Clinically, cutaneous anthrax (Fig. 2) can present as carbuncular (anthrax carbuncles), oedematous (malignant oedema), or bullous or erysipeloid lesions [44, 76, 78]. If treatment is started early, prognosis is good in uncomplicated cases. The differential diagnosis of cutaneous anthrax includes a wide range of infectious, parasitic and non-infectious conditions (Table 2).

Oropharyngeal and gastrointestinal anthrax. Oropharyngeal anthrax (anthrax angina) and gastrointestinal anthrax most often result from the ingestion of infected slaughterhouse products (meat, dry meat, offal, minced pork, sausages) and milk that had been insufficiently cooked or heated $[6,27,28,38,79,80]$. Dobreizer [28] observed outbreaks of intestinal anthrax caused by contaminated drinking water. Oropharyngeal anthrax can result also from the inhalation of spore-containing dust that enters the oral cavity through the nose and trachea and is swallowed $[38,73,81]$. This form of manifestation can be associated with massive neck oedema and may therefore be initially mistaken for diphtheria [82]. Other conditions to be considered in the differential diagnosis are listed in Table 2.

Inhalation anthrax. Spore-containing aerosols or dusts (with a particle size $<5 \mu \mathrm{m}$ ) that reach the deep airways can cause inhalation anthrax, which is also known as pulmonary anthrax, ragpickers' disease or woolsorters' disease [83-88]. This form of anthrax often begins with non-specific influenza-like prodromal symptoms and a brief period of seeming recovery. In many cases, infection leads to lifethreatening respiratory distress syndrome as a result of severe haemorrhagic necrotic inflammation of the mediastinum, hilar lymph nodes and pleura [6, 28, 61, 67, 89, 90]. Differential diagnosis includes a wide range of bacterial infections (Table 2).

Inhalation anthrax is a typical occupational disease. Until the 1950s, cases of inhalation anthrax occurred in workers who processed infected skins, hides, rags, wool, or animal hair from anthrax endemic regions [28, 38, 41, 91-95]. With the exception of a single case in 1976, no more such cases of anthrax have been reported in the USA since the 1960s [96] as a result of the introduction of the anthrax vaccination [96] licensed in 1970 (https://www.avma.org/KB/Resources/ LiteratureReviews/Pages/Anthraxfacts; last assessed 19 March 2020). Occasionally, inhalation anthrax was caused by imported spore-containing bone meal fertilisers and African goat skins used for producing bongo drums $[28,68,72$, $97,98]$. If left untreated or if treated too late, all forms of manifestation can lead to sepsis syndrome and haemorrhagic meningitis, followed by death [44, 61, 75, 76, 99-101].

Injection anthrax. Another manifestation of anthrax was reported for the first time in 2000 in an injecting heroin addict in Norway and later in other European countries $[102,103]$. These cases presented with severe inflammation of subcutaneous and muscle tissue (necrotising fasciitis, compartment syndrome) with a relatively high mortality rate [103-107]. Since this uncommon form of anthrax was seen after para-venous injection of heroin probably contaminated with spores, it was termed "injection anthrax" [101, 105, 108, 109]. Between 2000 and 2013 alone, a total of 230 suspected cases of injection anthrax were reported in Britain, Norway, Denmark, France, and Germany [109]. It is assumed that the heroin had been contaminated with spores (soil, infectious animal blood, infectious animal skins, etc.) in the country of origin or in transit [107, 110]. In 1903, Risel [28] reported a similar case of anthrax caused by drugs that had been wrapped in raw animal skins.

At present, it is not easy for clinicians to detect anthrax at an early stage. Even typical forms of anthrax are associated with problems in differential diagnosis. In an anthrax outbreak in a Swiss textile factory, for example, most cases were diagnosed only retrospectively [111]. Following the postal anthrax attacks in the United States in 2001, the index patient presented to half a dozen physicians and visited two emergency rooms before receiving the diagnosis of cutaneous anthrax [112]. 
Table 2. Possible clinical presentations of anthrax $[6,27,28,44,61,68,72,74,75,87,88,91,95,101,105,107,110,111,113,192,196,313$, 356-370]

\begin{tabular}{|c|c|c|c|}
\hline Cutaneous anthrax & Inhalational anthrax & $\begin{array}{l}\text { Oropharyngeal/ Intestinal } \\
\text { anthrax }\end{array}$ & $\begin{array}{l}\text { Injection (subcutaneous) } \\
\text { anthrax }\end{array}$ \\
\hline $\begin{array}{l}\text { Non-specific skin infection } \\
\text { (paronychia) }\end{array}$ & $\begin{array}{l}\text { Severe acute respiratory disease } \\
\text { Influenza-like illness }\end{array}$ & $\begin{array}{l}\text { Diphtheria } \\
\text { Tonsillitis }\end{array}$ & $\begin{array}{l}\text { Streptococcal cellulitis } \\
\text { Necrotising fasciitis }\end{array}$ \\
\hline $\begin{array}{l}\text { Staphylococcal furuncle, } \\
\text { carbuncle or cellulitis }\end{array}$ & $\begin{array}{l}\text { Type A influenza } \\
\text { Atypical community-acauired }\end{array}$ & $\begin{array}{l}\text { Streptococcal pharyngitis } \\
\text { Plaut-Vincent angina }\end{array}$ & $\begin{array}{l}\text { Non-specific inflammation } \\
\text { Abscess of skin and soft tissue }\end{array}$ \\
\hline $\begin{array}{l}\text { Streptococcal cellulitis, necrosis, } \\
\text { fasciitis or phlegmons }\end{array}$ & $\begin{array}{c}\text { pneumonia (L. pneumophila, } M . \\
\text { pneumoniae) }\end{array}$ & $\begin{array}{l}\text { Parapharyngeal abscess } \\
\text { Oropharyngeal tularaemia }\end{array}$ & $\begin{array}{l}\text { Deep thrombosis of leg veins } \\
\text { Compartment syndrome }\end{array}$ \\
\hline Haemorrhagic necrotic erysipelas & Bilateral haemorrhagic pleurisy & Peptic ulcer & Sepsis \\
\hline Furuncle-like swelling & Pulmonary tularaemia & Appendicitis & Phlegmons \\
\hline Necrotic carbuncle (B. pumilus) & Diphtheria & Bacterial peritonitis & Malignant oedema \\
\hline Gas gangrene & Tonsillitis & Acute abdomen & Severe soft-tissue infection \\
\hline Traumatic infection & Cervical lymphadenitis & Typhoid & $(\mathrm{SSTI})$ \\
\hline Pyogenic granuloma & Haemorrhagic gastroenteritis & Food poisoning & C. novyi type A infection \\
\hline Infected atheroma & Pasteurellosis & Acute gastroenteritis & \\
\hline Orbital cellulitis & Pneumonic plague & Ileus & \\
\hline Dactrocystitis & Acute bronchitis & Cholera-like disease & \\
\hline Infected necrotic abrasion & Mediastinitis & Food poisoning & \\
\hline Oedematic swelling & Fever of unknown origin & Necrotising enteritis caused by $C$. & \\
\hline Infected insect bite & & perfringens & \\
\hline Ulcero-glandular tularaemia & & Bacterial or amoebic dysentery & \\
\hline Ulcero-cutaneous tularaemia & & Mesenteric ischaemia & \\
\hline Gas gangrene & & & \\
\hline Pasteurellosis & & & \\
\hline Orf & & & \\
\hline Cowpox & & & \\
\hline Vaccinia & & & \\
\hline Plague (flea bites) & & & \\
\hline Glanders & & & \\
\hline Erysipelas (V. vulnificus) & & & \\
\hline Tropical ulcer & & & \\
\hline Syphilitic chancre & & & \\
\hline Cutaneous leishmaniasis & & & \\
\hline Foot-and-mouth disease & & & \\
\hline Nodular dermatitis & & & \\
\hline Ecthyma contagiosum & & & \\
\hline $\begin{array}{l}\text { Necrotising herpes, herpes zoster } \\
\text { (Diabetic) Mucormycosis }\end{array}$ & & & \\
\hline Bursitis & & & \\
\hline Emboli, thrombosis, vasculitis & & & \\
\hline Bites (viper, spider, bat, insects) & & & \\
\hline Rat-bite fever & & & \\
\hline Rickettsiosis & & & \\
\hline Artefacts & & & \\
\hline Ferret bites & & & \\
\hline Werlhof's disease & & & \\
\hline
\end{tabular}

Since anthrax is a rare disease, medical and veterinary practitioners are seldom confronted with it during their training and professional life resulting in a low awareness [101, 113-115].

For this reason and because of the non-specific initial symptoms of anthrax, there is a relatively large spectrum of initial diagnoses (Table 2) and it is often too late when anthrax is considered in the differential diagnosis [33, 72, $107,112,116]$. Moreover, clinically inapparent or subclinical infections with $B$. anthracis which heal without specific treatment and thus remain undetected are not uncommon [117-119].

Injection anthrax is particularly difficult to diagnose since it shows pathognomonic signs and symptoms that are different from those of classical forms of anthrax. In some cases, these unfamiliar characteristics led to delays of 3-12 days from hospital admission to diagnosis [107]. Similar types of soft-tissue inflammation can also be seen after wound infections caused, for example, by Staphylococcus, Streptococcus, Vibrio or Clostridium species (Table 2). 


\section{Biosafety issues}

The World Organisation for Animal Health (Office Internationale des Epizooties - OIE) lists anthrax as a List B notifiable disease. B. anthracis is a risk group 3 biological agent that was classified as a Category A bioterrorism pathogen by the Centers for Disease Control and Prevention (CDC) because it has high bioterrorism potential (www.bt. cdc.gov/agentlist_category.asp, last accessed 19 March 2020).

In Germany, the Biological Agents Ordinance (Biostoffverordnung) provides that $B$. anthracis may be handled only in Biosafety Level 3 laboratories. In accordance with Sections 6, 8 and 9 of the German Act on Prevention and Control of Infectious Diseases in Man (Infektionsschutzgesetz), suspect cases and clinical cases of anthrax and deaths from anthrax must be reported. Table 1 shows that persons at particular risk of exposure and infection are workers in animal husbandry settings as well as workers who slaughter animals, or process, pack, store, transport or use raw animal hides and skins, bristles, hair, wool, intestines, bones, horns or products made from them, which are imported from endemic areas in subtropical and tropical countries [6, 28, $38,49,60,78]$.

\section{Preventive approaches and their obstacles}

Most industrial countries were able to control animal anthrax through effective measures for preventing epizootic diseases, e.g. police orders and livestock vaccination, and to largely eliminate autochthonous foci of anthrax [6]. As an occupational disease, industrial anthrax has been rare in Germany since the 1990s owing to strict regulations and controls on the importation of raw animal products from endemic areas. The last case was reported in 1994 [49, 105].

By contrast, anthrax is still highly endemic in parts of the Middle East, Asia, Africa and South America because of a lack of measures to control epizootic diseases or because the availability of veterinary and public health services is limited as a result of economic crises or political or military conflicts $[6,27,120]$. For cultural reasons or out of necessity, meat, hair and skins of diseased or dead animals are often still used in these regions and anthrax carcasses are not burned but buried without compliance with veterinary hygiene standards. Such sites, which are not always designated as animal burial sites, can be the source of anthrax outbreaks in livestock and the local population even after decades [6, 31, 64].

For this reason, potential exposure to anthrax spores and a risk of infection still cannot be excluded for construction, waste disposal, and wastewater treatment workers, especially at former industrial sites such as tanneries, leather factories, rendering facilities and knackeries [49, 64, 78, 121]. As a result, activities involving the movement of soil (e.g. construction of buildings, roads or canals) in stationary anthraxaffected areas (SAA) are subject to special biosafety regulations in Russia and some other former Soviet republics [59, 64, 122].
In the European Union, too, a directive requires that workers in potentially contaminated areas (e.g. former tanning facilities) be protected from micro-organisms classified as biological agents that may be a hazard to human health [123, 124]. In Germany, the Civil Engineering Professional Association passed safety regulations in 1990 for the civilian sector in order to protect workers from infection with Group 2 soil-borne pathogens during activities involving soil disturbance [124]. These regulations also apply to spores from Clostridium species (e.g. the causative agents of tetanus and gas gangrene) and B. anthracis.

Preventive challenges from a military medical point of view. No data are available on potential health hazards and any required protective measures associated with military exercises or combat operations in endemic regions. This is of military medical relevance since such activities involve the movement of large amounts of soil, too, which may lead to the release of anthrax spores.

During World War II, an area of 3.3 million $\mathrm{km}^{2}$ was affected by combat activities in Europe [125]. Grenade and bomb attacks as well as military vehicle movements caused considerable damage to the earth's surface and structure. Several billions cubic metres of earth were moved for the building of field fortifications (e.g. trenches, bunkers, shelters, roads, and wells) and soil-microflora was brought from deeper layers to the surface of the earth [125]. In World War I, years of trench warfare likely resulted in similar soil damage.

During both wars, natural anthrax foci and potentially contaminated industrial sites in occupied areas were probably affected by military activities. Time and again, members of the land forces of the countries involved in the wars (and in particular infantry, armoured and engineer units) had close contact with soil and were exposed to dust. When soldiers were wounded, spore-containing soil could enter wounds together with projectiles, fragments or other objects and could cause infection (cutaneous or injection anthrax) similar to the development of gas gangrene or tetanus.

It is unknown, however, whether sufficient amounts of virulent spores of $B$. anthracis from soil foci were released into the environment and presented a risk of infection for military personnel and military animals (e.g. riding animals or draught animals) and for the local population and their animals.

Furthermore, anthrax is of relevance in terms of the biological medical defence of armed forces. B. anthracis spores can be used as biological warfare agents and have been tested, produced and weaponised by several countries on the basis of biological weapons programmes and have been used for terrorist and other criminal purposes [126134]. Soil, vegetation, roads and buildings were contaminated by spores from highly virulent laboratory strains as a result of British tests with anthrax spores on Gruinard Island in 1942 and 1943, the laboratory accident in Sverdlovsk in 1979, and the postal anthrax attacks in the United States in 2001 [9, 68, 135]. Only after several large-scale decontamination operations was it possible to use the contaminated 
areas again, for example Gruinard Island in the late 1980s $[48,136]$.

The need for large-scale decontamination was based on the assumption that humans can contract inhalation or cutaneous anthrax when they breathe in spore-containing soil particles floating in the air or when they come into contact with contaminated surfaces.

\section{Aim of the review}

Against this background, the present review investigates whether direct contact with anthrax spores or exposure to airborne anthrax spores from spore-contaminated soils or surfaces can lead to anthrax infections in military personnel. Where appropriate, recommendations for protecting military personnel during deployments in endemic areas are suggested. In addition to the presented speficially military medical experience, a more general summary of reports on soil-borne and air-borne anthrax transmission is shown in the Supplementary material 1 [137-172], [173-194], [195240].

\section{ANTHRAX IN WAR}

\section{Anthrax before the era of microbiology}

From ancient times until the 19th century, anthrax was always present in wartime. In August 1,623 during the Thirty Years' War, for example, Wallenstein lost approximately 15,000 of 20,000 men, his cavalry and almost all of his draught animals when his forces moved across pastures in Silesia and Hungary. These pastures were obviously contaminated with anthrax spores and led to devastating outbreaks of cutaneous anthrax (carbuncles) and intestinal anthrax (bloody diarrhoea) [241]. In times of war and need, soldiers often wore untanned fur and skins from diseased or dead animals underneath their armour in order to provide padding, to protect their skin or to protect themselves from the cold and they ate infected meat [241]. When Finland was occupied by Russia in 1719, anthrax spread from horses, cattle, sheep and pigs to soldiers and the civilian population [241].

In the spring of 1745 , during the Silesian Wars, Prussian grenadiers suffered from "bubonic plague" or more likely from anthrax carbuncles [241].

At that time, many people died after contact with apparently contaminated wool in weavers' villages in Silesia. Their signs and symptoms included large malignant buboes, bloody cough and fever (presumably inhalation anthrax in our opinion) [241].

The persistent recurrence of epizootics among horned animals or sheep persuaded Empress Maria Theresa in 1753 to pass the first Regulations on Livestock Diseases (ViehSeuch-Ordnung) for the territory under her rule. They stipulated that everything that had come into contact with the animal had to be destroyed, all livestock that had been killed because it had been affected by the epizootic had to be buried in the ground to a depth of five to six feet, and the pits had to be covered with lime and then with earth [241].

During Napoleon's siege of Glatz in the anthrax year of 1807, epizootics were observed in horses and then outbreaks of cutaneous carbuncles and bloody diarrhoea occurred among Bavarian and Wurttembergian soldiers [241]. Dominique Jean Larrey, who was Napoleon's personal physician and surgeon-in-chief, observed repeated outbreaks of "charbon" (the French word for anthrax) especially during the French invasion of Russia [241]. Supply problems and hunger apparently forced the French soldiers to slaughter animals that suffered from anthrax and to eat the meat and use the skins of these animals.

The last major outbreaks of anthrax (syn.: "Siberian plague" or "Siberian ulcer", "sibirskaya yazva") occurred on the European part of Russia between 1864 and 1870. At that time, several thousand deaths were reported throughout Russia, and 65,000 horses, cows and sheep as well as 528 humans died in Novgorod Governorate, only [28, 91, 241].

During the American Civil War, diarrheal diseases, malaria, typhus fever (typhoid fever, typhus), pneumonitis and pleuritis, sexually transmitted infections, other "miasmatic diseases", and diphtheria were the diseases that most commonly affected the northern soldiers from 1 May 1861 to 30 June 1966. Anthrax was not included in statistical data [242].

In Germany, 5,228 of 25,000 horses of the VII and VIII Army Corps underwent treatment in a veterinary facility in 1866; anthrax, however, was not identified as a cause of disease [243].

On 18 May 1867, the Kingdom of Bavaria passed the Law on Contagious Animal Diseases Act (Gesetz über ansteckende Viehkrankheiten) in order to provide protection against epizootics; this law was also adopted by the Military Veterinary Service of the Bavarian Army [244]. The law prohibited the use of carcasses of animals known or suspected to be infected with anthrax [244].

No anthrax cases in animals or soldiers of the Royal Bavarian, Wurttembergian and Prussian Armies were reported between 1867 and 1873 (with the exception of the war from 1870 to 1871) [245-248]. At that time, the main focus of military medical care was on typhoid fever, erysipelas, intermittent fever (malaria), dysentery, cholera, acute respiratory diseases, inflammation of the tonsils and lungs, tuberculosis, scarlet fever, measles, venereal diseases and skin conditions such as footsores and saddle sores, skin ulcers and abscesses, as well as inflammatory conditions, furuncles, and exanthems [248].

Available data do not allow conclusions to be drawn on whether or not anthrax occurred during the Franco-German War from 1870 to 1871 . It should be noted that this zoonotic disease was not yet notifiable upon suspicion or diagnosis in the German armies at that time [244]. For this reason, there was no information on anthrax in reports on Bavarian hospital trains [249] and the 4th Royal Bavarian Division $[245,250]$, in an analysis on losses caused by weapons and diseases during war [250], in the several volumes of the Medical Report on the German Armies in the Franco- 
German War of 1870 and 1871 [247, 250, 251, 252], or in Die Kriegschirurgen und Feldärzte Preussens und anderer deutscher Staaten in Zeit- und Lebensbildern [253], which presents military surgeons of the Prussian army and other German states in several volumes. The same applies to the Statistical Medical Report of the Royal Prussian Army and the XIII (Royal Wurttembergian) Army Corps between 1870 and 1873 (first quarter), with the exception of the war from 1870 to 1871 [246].

This relatively short military campaign involved typical diseases such as cholera, typhus, relapsing fever, typhoid conditions, smallpox, dysentery and malaria which cost the lives of 14,904 soldiers [248, 250].

A total number of 116,821 German soldiers were wounded in this war [247]. Of the 9,737 patients who were treated in field hospitals, 2007 died of (wound) erysipelas, hospital gangrene, wound diphtheria, pyaemia, septicaemia, acute purulent oedema, tetanus, and osteomyelitis [251]. There are no data specifying whether the patients had primary or secondary wound infections. Whether the abovelisted medical conditions also included anthrax remains unclear since microbiological diagnostic procedures were not yet available at that time.

Surgical management consisted of early wound drainage, debridément and the application of antiseptics such as potassium permanganate, aluminium acetate, chlorine water, zinc chloride, and carbolic acid, which were used to prevent the occurrence of the much-feared hospital gangrene [251].

During the war, the Veterinary Service treated approximately 21,000 injured and diseased horses, 1859 of which died [243]. At that time, anthrax, which was known to veterinarians as an epizootic, was never reported as a cause of disease or death.

During the war, Robert Koch came into contact with the disease when he was employed as a military physician in the Auvergne region in France in 1871. Sheep from local farmers died of anthrax when they grazed on "the green hills of death" [241]. "Damned pastures," "cursed hills" and "anthrax farms" or "dangerous mountains" were also found in Burgundy, Champagne, Dauphiné, Auvergne, Beauce, Sologne, Eure-de-Loire and Nivernais, where sheep became infected every year until the end of the 20th century [91, 241]. Similar foci existed in the German Reich in the Bavarian Alps, the Lower Rhine region, the District of Potsdam, and in the Provinces of Saxony (Mansfeld area), Silesia and Posen [91].

\section{Anthrax in the military and the civilian population before World War I}

When the Franco-German War was over, Koch worked as a district physician in Wollstein in the Province of Posen and investigated the anthrax outbreaks that occurred every year in animals, animal keepers, slaughterers, and veterinarians. In 1876 , Koch was the first to isolate and describe $B$. anthracis as the causative agent of anthrax and to demonstrate the role of anthrax spores in infection [254]. Koch was thus a founder of bacteriology as a science and a pioneer of laboratory diagnostics and the control of this epizootic both in the civilian and military sectors of the 19th century.

In the 1870s, Louis Pasteur, Roux and Chamberland discovered the causes of the recurrence of epizootic diseases in anthrax regions and demonstrated the presence of infective anthrax spores in superficially buried animal carcasses after as many as seventeen years [241]. Infection recurred in animals that grazed on these sites or were fed dry feed or grass harvested from these sites. Since hides and skins from diseased animals were infective for several months or even years, tanners and brushmakers contracted the disease. Waters and adjacent pastures located below tanning facilities were contaminated with spores and provided infected material to existing or new anthrax foci [241]. Neither Koch nor Pasteur, however, described cases of human anthrax caused by contact with spore-containing grass or soil at contaminated sites.

Louis Pasteur, who developed the first anthrax vaccine and successfully tested it on sheep in 1881 and 1892, created the basis for preventive immunisation and anthrax control in animal populations, which are still effective today [241].

From 1873 to 1877 , a total of 13,698 service horses received treatment in the Kingdom of Saxony. Of these, 12 died of "anthrax-like diseases" (including anthrax and shingles of the head) [243]. Disease names were inaccurate at that time because it was not always possible to identify the causative agent.

On 18 May 1877, the Regulations Regarding the Reporting on Service Horses for Horse Veterinarians (Bestimmungen betreffend die Rapportführung und Berichterstattung über die Dienstpferde für Roßärzte) were passed in the German Reich for the Army Veterinary Service [244].

The Reich Law on the Prevention and Control of Livestock Epizootics (Reichsgesetz betreffend die Abwehr und Unterdrückung von Viehseuchen) of 23 June 1880 then required that anthrax cases be registered as well [244].

On 1 April 1881, the Implementing Law on Livestock Epizootics (Viehseuchen-Ausführungsgesetz) and the Instruction Regarding the Prevention and Control of Epizootics Among Horses of the Armed Forces (Epizootics Instruction) (Instruktion betreffend die A. und Unterdrückung von Seuchen unter Pferden der Truppen -Seucheninstruktion) were passed [244]. Large parts of these regulations were adopted by the Kingdom of Bavaria as well [244]. The Epizootics Instruction provided that horses be inspected, epizootics or suspected epizootics be identified, and an Epizootics Commission be sent to the unit affected by the epizootic. Animals suspected of having anthrax and all associated items of equipment had to be immediately isolated, the site where the animals were kept had to be cordoned off and investigated by the Epizootics Commission. Tar or petroleum had to be poured over dead animals before the carcasses were buried at a place designated by a police authority [244].

An Epizootics Reporting Service had to inform the responsible authorities of suspected or confirmed anthrax outbreaks, the course and the successful control of an outbreak. Moreover, personnel had to be educated about the 
signs and symptoms as well as the course and causes of anthrax. For the first time, the diagnosis of anthrax required microscopic identification and animal testing [244].

In 1886, a Military Veterinary Ordinance (Militär-Veterinärverordnung) was passed which contained all relevant regulations including an Epizootics Instruction in its Annex. In 1897, it was replaced by a new Military Veterinary Ordinance. This ordinance made anthrax in horses a disease that was notifiable upon suspicion [244].

The Military Veterinary Ordinance of 1906 provided that autopsies of horses that were killed or died in the setting of anthrax required the presence of a senior Veterinary Corps officer (Korpsstabsveterinär) and that autopsy reports be submitted to the General Command through official channels. In 1913, this provision was changed and autopsy reports had to be submitted directly to the General Command (Generalkommando) [244].

In 1909, the Reich Law on Livestock (Reichs-Viehgesetzes) [244] and new Epizootics Regulations (Annex II of the Military Veterinary Ordinance) were passed and made anthrax a disease that was notifiable upon diagnosis [244].

Anthrax provisions remained unchanged in the Epizootics Regulations of 1913, which was based on the Reich Law on Livestock of 1 May 1912. These provisions also regulated slaughter and meat inspections and the prohibition of slaughtering animals suspected of having anthrax in order to prevent human infections through the consumption of meat from anthrax-infected animals [91]. Effective vaccinations were available and effectively prevented the spread of the disease [91].

Epizootic control measures continuously improved so that only isolated cases of anthrax occurred in the animal population of German Army contingents in the pre-war period [255]. The Prussian Army, for example, reported only 66 sporadic cases from 1886 to 1914, most of which occurred during military exercises [255]. Most of these cases were caused by infected animal feed, stable bedding, or water (e.g. from collector wells). The Bavarian Army reported only a single case during this period. Rigorous epizootic control measures invariably prevented anthrax from spreading among animal populations [255].

In the German military, anthrax cases were rare and the incidence of this infectious disease continued to decrease from 32 cases in 1899/1900 to one case in 1908/1909 among members of the German armed forces [91] (Table 3).

In the colonies of the German Reich, increased numbers of anthrax cases [256] were observed in German South West Africa during the rainy season in 1905/1906 and occurred

Table 3. Anthrax cases in the Prussian, Saxon and Wurttembergian Army Corps [91]

\begin{tabular}{lccc}
\hline Year & Cases & Year & Cases \\
\hline $1899 / 1900$ & 32 & $1904 / 1905$ & 7 \\
$1900 / 1901$ & 24 & $1905 / 1906$ & 9 \\
$1901 / 1902$ & 21 & $1906 / 1907$ & 6 \\
$1902 / 1903$ & 6 & $1907 / 1908$ & 1 \\
$1903 / 1904$ & 14 & $1908 / 1909$ & 1 \\
\hline
\end{tabular}

Table 4. Officially reported human anthrax cases in Germany [91]

\begin{tabular}{ccc}
\hline Year & Number of cases & Case-fatality rate ${ }^{\mathrm{b}} \%$ \\
\hline 1904 & $123(10)^{\mathrm{a}}$ & 8.1 \\
1905 & $114(16)$ & 14.0 \\
1906 & $133(18)$ & 13.5 \\
1907 & $156(21)$ & 13.5 \\
1908 & $120(19)$ & 15.8 \\
\hline
\end{tabular}

${ }^{\mathrm{a}}$ In parantheses: number of deaths

${ }^{\mathrm{b}}$ Case-fatality rates were added.

among draught animals (oxen) and local personnel accompanying military transport elements and among personnel of transport elements. Occasional cases were also reported in equids and the local population in German East Africa [257]. Cutaneous anthrax was the most common form of the disease since dried skins of cattle that had died of anthrax were used as bed coverings. By contrast, there is no evidence of the occurrence of anthrax in Cameroon, China or Turkey [257] although the disease was endemic in China and Turkey.

In the German Reich, the control of anthrax in humans was regulated in the Law on Epidemics of 28 August 1905 and its implementing regulations [91]. This law required the reporting of all cases of disease, deaths and suspected cases and defined the necessary isolation and disinfection procedures. In Germany, special trade and industrial regulations applied to the production, handling, storage and distribution of objects capable of spreading anthrax [91].

In the civilian sector, the authorities that enforced trade and industrial regulations increased their efforts to control anthrax in livestock settings and thus continuously reduced the risk of infection for humans. At the same time, the risk increased for those whose work involved processing infectious spore-containing animal products (e.g. meat, bones, hides, skins, hair, or bristles), most of which had been imported from endemic areas [28].

From 1889 to 1899 , a total of 290 anthrax cases were reported and consisted of 180 butchers, 48 shepherds, 31 wool sorters, 24 knackers/renderers, and 7 veterinarians [38].

From 1899 to 1908, a total of 646 anthrax cases (Table 4) were officially registered in the German Reich and included 203 butchers, 8 veterinarians, 28 knackers/renderers, 19 shepherds, 8 tanners, 2 brushmakers, 5 meat inspectors, and one livestock trader $[28,91]$.

During the period 1910-1929, anthrax cases occurred as a result of emergency slaughtering (39\%), the handling of living (1\%) and dead animals (9\%), the handling of hides and skins (31\%) and animal hair and bristles (8\%), or other occupational activities (2\%). In $10 \%$ of the non-occupational anthrax cases, the source of infection remained unknown [60]. In no case was contact with spore-containing soil reported as the cause of anthrax in humans.

The reduction in the number of anthrax cases in the German Reich was probably one of the reasons why anthrax was the subject of only three of 510 articles that appeared from 1903 to 1914 in the Centralblatt fur Bakteriologie, Parasitenkunde und Infektionskrankheiten, the German 
central journal of bacteriology, parasitology and infectious diseases [258]. In these articles, two patients with cutaneous anthrax had become infected by contact with spore-containing animal products.

Likewise, the Deutsche Militärärztliche Zeitschrift, which was the professional journal of the German Army Medical Service, did not report any cases of anthrax during the period 1871-1914. The focus of attention was on typhoid fever, tuberculosis, cholera, tetanus, scabies, plague, smallpox, pneumonia, colds, influenza, dysentery, diphtheria, and venereal diseases [259]. These were also the most common infectious diseases in the peacetime Prussian Army between 1867 and 1872 [248].

A total of 261 anthrax cases were reported in England between 1889 and 1904 . Of these, 88 patients had processed wool, 86 patients had handled animal skins, 76 patients had been occupationally exposed to bristles and brushes, and 17 patients had become infected in other industrial situations [38].

In Russia, 268,000 cases of anthrax and a mortality rate of $25 \%$ were reported during the period 1896-1913 [260]. The number of cases of animal anthrax was 50 times higher than the number of human anthrax cases. The majority of human anthrax cases resulted from handling skins and hides in industrial settings but also from exposures at home.

From 2,634 occupational anthrax cases reported between 1884 and 1916, 1,466 were farmers or owners of livestock, 37 shepherds, coachmen or blacksmiths, 824 workers processing wool and sheepskin, 257 tanners, and 36 persons processing animal hair, bristles and horns, and one veterinarian [260].

No German, English or Russian statistical data on occupationally related infections suggested that anthrax cases were caused by direct contact with spore-contaminated soil.

\section{Anthrax during World War I (1914-1918)}

Anthrax in animal populations. In World War I (19141918), the German Field Army (Feldheer) had an average of $1,236,000$ horses [261]. A total of 1,372,000 animals were treated in horse hospitals; there are, however, no data on the number of anthrax cases among these animals [261].

Medical reports for horses required that unit, depot, and hospital veterinarians registered and reported cases of anthrax, glanders and tetanus [262]. The German Army Veterinary War Report of 1914-1918 (Kriegsveterinärbericht des deutschen Heeres 1914-1918) [262] noted that there were sporadic anthrax cases in horses in all theatres of war. Moreover, outbreaks occurred between January 1916 to August 1918 in 39 formations on the Western Front and in 48 formations on the Eastern Front.

Statistics on the number of military horses that were infected with or died of anthrax are unavailable. Likewise, the report did not provide information on whether wartime veterinary research facilities of the Western Army used methods for diagnosing anthrax. The following is known about the anthrax situation on the fronts.

At the Eastern front thirty cases of anthrax among horses were registered in Lithuania, the Bialystok-Grodno district and Courland. Further cases occurred on two farms during the period 1916-1918.

At the Southern front (Romania, the Danube Front), larger numbers of anthrax cases in horses were reported.

Major outbreaks occurred in cattle at livestock depots or during transport in the General Government of Warsaw, at Modlin Headquarters, in Brest-Litovsk (Bug area), in cattle and sheep on the Danube Front, and in pigs on the Western Front in Roulers in 1915.

On 5 December 1916, the chief veterinarian in the East prohibited the dissection of animals infected with anthrax because of the risk of infection during animal autopsies: "During the dissection of a cow that had died of anthrax and in which the presence of $B$. anthracis had earlier been bacteriologically confirmed, two persons, including the veterinarian who performed the autopsy, contracted an anthrax infection. Because of the risk of disease transmission during the dissection of animals with diseases that are transmissible to humans, the Supreme Commander of All German Forces in the East (Oberbefehlshaber Ost) prohibits the dissection of animals if the animal that died or was killed has a bacteriologically confirmed diagnosis of anthrax."

In addition, he issued the following regulations for his area of responsibility: "Animals known or suspected to have anthrax and all associated items of equipment must be immediately isolated. All other horses of the affected formation can be used for military duties without limitations both inside and outside the premises.

The stalls where horses known or suspected to have anthrax are kept must be disinfected and cordoned off after the removal of litter. Carcasses, as well as discharges, feed, and the litter at the site where diseased horses were kept, must be destroyed in a safe manner at remote locations in accordance with the Epizootics Regulations. Skinning is forbidden.

Regardless of immediate action taken, the diagnosis of anthrax must be confirmed by microscopy. Blood and splenic pulp specimens (Annex 2 of the Epizootics Regulations) must be sent to a blood analysis facility.

Sites where anthrax carcasses were buried must be enclosed by a fence and "Anthrax!" signs must be visibly posted; grass, hay, etc. from such sites can cause anthrax. The causative agents of anthrax are extremely resistant and difficult to destroy. For this reason, carcasses, discharges etc. must be destroyed thoroughly." [262].

In September 1917, the Eastern Administration reported that anthrax as an infectious disease was "seuchenpolizeilich" not relevant [262].

In 1917 and 1918, carcass disposal facilities were established in the east, in the west and in the Balkans [262]. At these sites, too, the skinning of animals known or suspected to have anthrax was forbidden with a view to preventing the spread of epizootics or their transmission to humans.

In the period 1916-1918, German agents were suspected of covert attempts to infect horses, mules, cattle and reindeer that were bound for the armies of the Entente Powers with anthrax spores and glanders in Romania, France, Argentina, Finland, Spain, and the United States [129]. There is no clear 
evidence, however, whether, and to what extent, these efforts were successful [129].

Anthrax in the armies of World War I. In World War I, 17,837,860 soldiers served in the German Field Army (Feldheer) and 8,780,728 soldiers in the Replacement Army (Ersatzheer) [263]. During the four war years, 4,819,557 soldiers $(5,587,244$ soldiers according to [264]) were wounded and 14,657,324 soldiers were affected by diseases [265].

The number of soldiers who acquired infectious diseases in the field was 1,426,091 [263]. Of these, 449,702 received treatment in field hospitals primarily for influenza (11.2\%), inflammation of the tonsils (6.5\%), dysentery (5.3\%), typhoid fever $(4.0 \%)$, malaria $(4.0 \%)$, other infectious diseases $(4.0 \%)$, diphtheria $(0.77 \%)$, typhus $(0.28 \%)$, and tuberculosis $(0.28 \%)$ [265].

According to Report No. 18 of the German Medical War Report 1914/1918 [265], there is evidence of only a single case of anthrax in the German Field Army and Replacement Army. The patient was "an assistant pointsman with a history of five days of stomach pain who was dying when he arrived at the field hospital in Warsaw." Anthrax lesions involving the right tonsil, the stomach and the intestine were detected during the post-mortem examination.

Soldiers of the Field and Replacement Armies most commonly suffered from diseases of the skin, appendages and subcutis (e.g. boils, inflammation of cellular tissue and sweat glands, abscess formation, or similar conditions) (1,049,947 diseased soldiers). In addition, 3,600 wounded soldiers had tetanus $[263,265]$.

Most injuries were caused by all types of fragments of munition (58.7\%) and infantry projectiles (35.7\%) [263].

Initial surgical wound care was provided at main dressing stations and front-line field hospitals and consisted of the application of iodine to the wound area, the removal of foreign particles from open wounds, bleeding control, and immobilisation [266].

According to Läwen et al. [266], "most projectiles that were removed from human bodies contained (skin-borne and soil-borne) micro-organisms from particles of soil, clothing or skin that were dragged into the wounds; moreover, there were fragments and secondary projectiles, stones, pieces of wood, coins, metal particles, etc." and "clothing must be considered as a means of transmitting soil-borne bacteria into wounds". This observation was confirmed elsewhere [267, 268].

A poster from the Military Academy of Berlin which dates back to that time shows examples of foreign bodies embedded in wounds (Fig. 3).

A wide variety of micro-organisms were detected in fresh war wounds and on projectiles after only one or two hours [266]. Among them were staphylococci, streptococci, Micrococcus tetragenus (Gaffkya tetragena), Gram-negative diplococci, diphtheria-like bacilli, Proteus-like bacteria, Bacterium (Escherichia) coli, and bacilli that are commonly found in the upper soil layers.

Klose [269] investigated 111 cultures from combat areas in the vicinity of Verdun, Flanders, Brest-Litovsk and the Vosges and performed serological tests on 130 strains from

\section{Fremdkörper in Wunden}

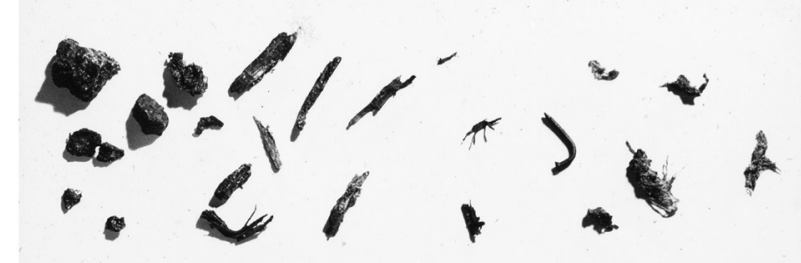

Sranalsplitter, Holzteile, Nagel, Stoffetzen i. einer Oberschen-

kelwunde

$$
\text { I an } \mathrm{CO} \text { Vergiptung }
$$

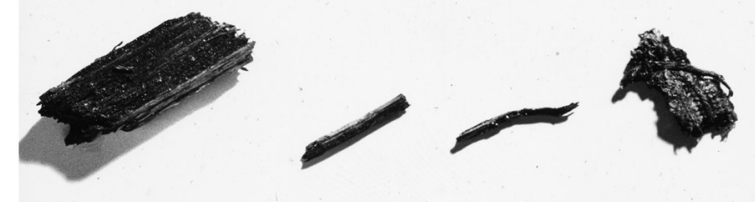

Holzteile u. Kleiderfetzen i. einer grossen Oberschenkelwunde I an CO Vergiftung
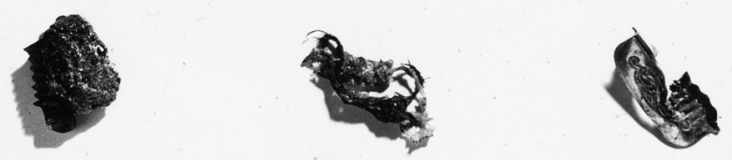

Stoppetzen u. Hosenträgerschnalle bei A.S.-Steckschussd Lunge I an Verblutung
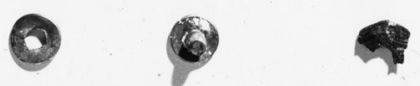

Doppelknopp eines Tornisterriemens mil Lederscheibe i Lungensleckschusswunde bei A.S. Sleckschuss der L. Brustseite

$$
\text { Tt an Empyem }(250 \mathrm{ccm})
$$

Fig. 3. Foreign bodies in war wounds. Photograph (repro): Military Pathology Collection of the Military Medical Academy, Berlin, 1945, missing. German Armed Forces Medical Academy, Military History Collection, no signature

wound and autopsy specimens. He detected Welch-Fraenkel gas gangrene bacilli in $34 \%$, blackleg bacilli in $32 \%$, and Bacillus putrificus Bienstock, the causative agent of malignant oedema, in $24 \%$ of the specimens.

Klose [268] further analysed 12 soil samples that he collected in different sections of the Western and Eastern Fronts during the war and detected all three types of the causative agents of gas oedema in seven samples and two types of the causative agents in five samples. These agents were often found in mixed infections when contaminated soil entered the wound together with fragments and pieces of clothing. For this reason, the samples had to be incubated under strictly anaerobic conditions for several weeks and animal tests were required. It was, however, not always possible to meet these requirements [268]. Apparently, anthrax spores were not detected.

Läwen et al. [266] detected bacteria in fresh war wounds and on projectiles after only one or two hours. Among these 
Table 5. Items that caused primary wound infections during World Wars I and II, the Korean War and the Vietnam War and composition of the primary wound micro-flora $[263,266-272,290,295,302,311,312,315-319,328,350]$

\begin{tabular}{lcc}
\hline $\begin{array}{l}\text { Primary wound infection by } \\
\text { contaminated items }\end{array}$ & Composition of primary wound micro-flora ${ }^{\text {a }}$ \\
\cline { 2 - 3 } & Soil micro-flora & Body micro-flora \\
\hline $\begin{array}{l}\text { Handgun or machine gun projectiles } \\
\text { Grenade fragments }\end{array}$ & Gas gangrene and gas oedema complex: & Staphylococcus spp. \\
High-velocity missiles & Cl. perfringens, Cl. novyi, Cl. & Streptococcus spp. \\
Pieces of clothing & hlacklelyticum & Micrococcus tetragenus \\
Pieces of wood & Clostridium tetani & Gram-negative diplococci \\
Metal particles & Fusiform bacteria & E. coli and coliform bacteria \\
Stones & Bacillus spp. (e.g. hay bacilli) & Proteus-like bacteria \\
Soil particles & Anthrax-like bacilli & Corynebacterium spp. \\
Coins & & Pseudomonas spp. \\
Parts of buildings & & Klebsiella spp. \\
Foreign corpses & & Hafnia spp. \\
Human and animal faeces & & Citrobacter spp. \\
& & Providencia spp. \\
\end{tabular}

${ }^{a}$ Most of the bacterial species included in this table were also isolated from soil and water samples.

were staphylococci, streptococci, diplococci, M. tetragenus, Bacterium coli, Proteus-like bacteria, and micro-organisms that are found in the upper soil layers such as Fraenkel's gas bacillus, bacilli that cause malignant oedema, tetanus bacilli, other gas-forming anaerobic organisms, diphtheria-like bacilli, anthrax-like bacilli with or without spores, and hay bacilli.

It is interesting to note that French researchers identified a similar spectrum of pathogens in war wounds [266].

Klose [267] reported that most wound infections were caused by anaerobic bacteria in wartime and by aerobic bacteria in peacetime. From the very first years of the war, gas oedema, gangrene, phlegmons and malignant oedema were common in trench soldiers and appeared in almost epidemic numbers [267, 269]. Trench warfare was primarily associated with wounds from indirect projectiles and primary wound infections that were mainly caused by anaerobic bacteria that are ubiquitous in the soil [270].

Not all organisms that entered wounds, however, had pathogenic effects [270, 271].

Neither Klose nor later authors who studied the wound infections of World Wars I and II mentioned B. anthracis as a pathogen or reported the occurrence of a type of wound anthrax [271, 272] (Table 5).

In the multi-volume Handbuch der Ärztlichen Erfahrungen im Weltkriege 1914/1918 (Handbook of Medical Experiences During the World War of 1914-1918) [273], Matthes reported five patients with intestinal anthrax who showed acute cholera-like signs and symptoms and then died. Apart from these five cases, two cases were mentioned in the German Army Veterinary War Report [262] and one case in the German Medical War Report 1914/1918 [265] so that there were altogether eight anthrax cases during the entire war.

Anthrax, however, was not mentioned as an infectious disease or as a cause of wound infections in statistics on communicable diseases.

Diseases of epidemiologic relevance were typhoid fever, paratyphoid fever, shigellosis, Asian cholera, Weil's disease, typhus, smallpox, malaria, meningococcal meningitis, diphtheria, influenza, and Russian trichinosis [265, 273]. A similar spectrum of infectious diseases was found in prisoner-of-war camps [266]. The German Congress on Internal Medicine that took place in Warsaw in 1916 also addressed the aforementioned wartime epidemics but did not discuss anthrax [260].

Anthrax thus was not of relevance to the German Army Medical Service in the various theatres of war, which included highly endemic regions such as the Balkans, Eastern Europe and the Middle East. For this reason, Hoffmann [273] concluded in retrospect that "Army epidemics like those from the past no longer exist. Robert Koch, the great genius, has broken their power by his aetiological research."

Problems were mainly associated with hygiene practices at battle positions, trenches and shelters when measures were taken to drain off water and dry out the ground or when latrines were established or disinfected [273]. The potential risk of exposure to, for example, anthrax spores in the soil or water was, however, not addressed.

During World War I, the number of wounded soldiers who received medical treatment was 367,500 in the French Army, 2,576,058 in the British Forces, and 260,783 in the American Expeditionary Forces [264]. There are no data on anthrax infections of wounds.

Morillon (personal communication) reported that there were only 15 anthrax infections in French Army soldiers serving on the front. These infections were single cases of typical cutaneous anthrax presenting as malignant pustules or malignant anthrax oedema. The initial lesions were located on the neck and chest in the majority of cases and on the face (frontal and temporal regions) in three cases. Dopter [274], a French microbiologist during World War I, described seven patients with cutaneous anthrax in the region of the neck and chest. They became infected as a result of wearing sheepskin jackets under their uniform during the cold season (Fig. 4). Contact with acute or previous animal 
cases of anthrax was excluded on the basis of investigations into the aetiology of the infections. There was no acute epizootic among livestock and the front lines did not run through endemic anthrax areas. Moreover, there was no evidence supporting the hypothesis that contamination was caused by anthrax carcasses that had been excavated when trenches were built.

Roger [274] assumed that the soldiers became infected most likely by spore-contaminated sheepskin hats that provided protection against the cold in winter. This assumption is supported by the fact that cutaneous anthrax occurred on the temples in those patients who wore hats with sheepskin ear flaps. Roger also reported that soldiers in the Russian army contracted anthrax because they wore uniforms with sheepskin applications [274].

Ireland [275] and Siler [276] observed that the U.S. Army reported a total of 149 primary admissions for anthrax ( 2 officers, 146 enlisted men, 1 case among native troops, 22 deaths) from 1 April 1917 to 31 December 1919. Of these, 100 cases were seen in the territory of the United States and 43 cases in the U.S. Army American Expeditionary Forces in Europe (excluding Russia). The majority of cases occurred sporadically in 22 camps across the entire United States, during transport, or upon arrival in France and England. It had already been known before the beginning of the war that

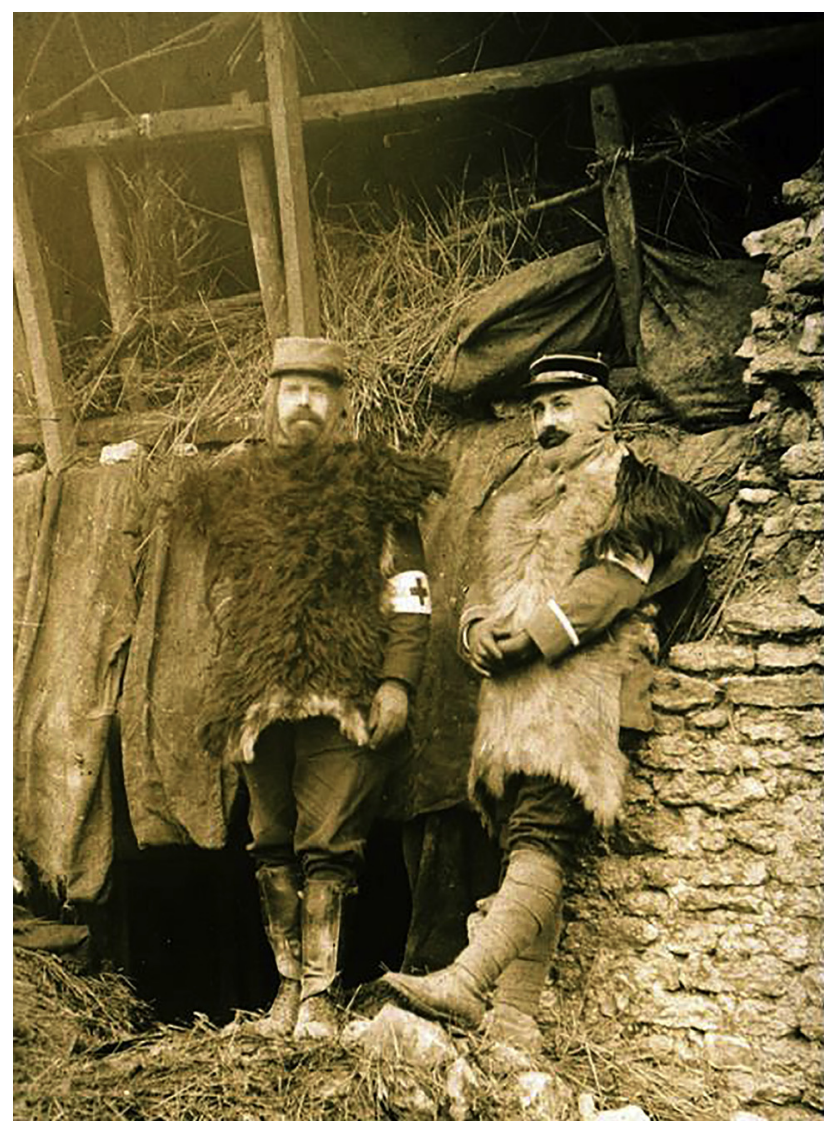

Fig. 4. Greeting card of World War I. Members of the French Medical service wearing sheepskin for protection in cold environments. Right: Medical officer (second lieutenant). Photography: Courtesy of Professor Marc Morillon, 2014 anthrax infections were most likely caused by contaminated animal products such as skins, hair, bristles (shaving brushes), and wool.

The majority of U.S. soldiers developed cutaneous anthrax, which presented as malignant pustules and was most commonly located on the shaving areas of the face and neck. Ireland [275] and Siler [276] reported no cases of inhalation anthrax, several cases of intestinal anthrax and anthrax meningitis as well as anthrax septicaemia in the majority of cases.

The United States Public Health Service found that soldiers used shaving brushes made of spore-contaminated horse hair that had been imported to the United States from China and Siberia and had been processed without having been cleaned and disinfected as required. Bacteriologists in the United States, England and France were able to detect agents in batches of these shaving brushes [275].

During the war, shaving brushes accounted for the majority of anthrax cases in the army, but leather chin straps and toilet soap were also found to be vehicles of transmission in some soldiers.

Ireland [275] did not report any anthrax cases that resulted from contact with soil possibly contaminated with spores (e.g. in trenches or shell craters) or that occurred after injury.

In Europe too, anthrax infections caused by spore-containing shaving brushes were a general problem during World War I since animal hair and bristles were often imported illegally because of the Blockade of Germany established by the Entente Powers [28]. This was also alleged to be the cause of anthrax cases that occurred in England (including 50 British soldiers) as well as in Denmark, the Netherlands and Italy [28, 38].

Already during the Russo-Japanese War (1904-1905) too, spore-containing sheepskin hats and jackets caused several hundreds of anthrax cases among Russian soldiers [38]. Shljachov [277] reported that $6.5 \%$ of all anthrax cases were caused by clothing made of the furs or hides of infected animals, too. These cases, however, were not included in the statistics of the armies of Tsarist Russia armies on infectious diseases during this war. According to these statistics, there were 90,902 patients with influenza, typhoid fever, malaria, dysentery, typhus, relapsing fever, and smallpox smallpox [278].

Before the Revolution, there were at least 15,000 cases of human anthrax in Russia each year [279].

During World War I from 1915 to 1917, the Russian armies reported a total of 5,069,920 wounded and 3,748,669 sick soldiers including 291,926 (6.5\%) patients with infectious diseases. Data on anthrax cases were not given. From February 1915 to January 1917, hospitals in Moscow Governorate provided treatment to 1,092 patients with infectious diseases [280]. Data on anthrax cases on the fronts or in hospitals are not available although there was likely no improvement in the epidemic situation of this zoonotic disease in the Eastern theatre of war when compared to the years preceding the war. Therefore, it is unknown whether the large Russian cavalry units were unaffected by anthrax.

Even before combat commenced in the theatre of war in Southwestern Asia and before the Ottoman Medical Service 
Table 6. Human and animal anthrax cases in Germany from 1913 to $1924[28,60]$

\begin{tabular}{ccccc}
\hline & & & \multicolumn{2}{c}{ Including } \\
\cline { 4 - 5 } Year & Humans & Animals & Horses & Cattle \\
\hline 1913 & 224 & 6,816 & 57 & 4,498 \\
1914 & 203 & 7,181 & 13 & 4,218 \\
1915 & 67 & 2,398 & 16 & 2077 \\
1916 & 37 & 2,320 & 13 & 1,093 \\
1917 & 34 & 1,370 & 22 & 1,064 \\
1918 & $29(18)$ & 1,002 & 15 & 826 \\
1919 & 18 & 743 & 23 & 600 \\
1920 & 35 & 875 & 19 & 699 \\
1921 & 80 & 1,315 & 38 & 943 \\
1922 & 118 & 1,506 & 59 & 1,136 \\
1923 & 106 & 1,569 & 175 & 1,196 \\
1924 & 49 & 1,512 & & 1,209 \\
\hline
\end{tabular}

was reorganised at the end of 1913, anthrax as well as typhus, cholera, relapsing fever, typhoid fever, glanders and influenza had a devastating impact on the armed forces and the population [281].

Epidemic and epizootic control measures were insufficient and affected by religious rules of Islam. In addition, there was a lack of qualified veterinarians, medications and vaccines [281, 282]. For example, the killing and burial of injured or sick animals was not permitted. These animals were left to vultures. As a result, outbreaks of epizootic diseases, especially glanders, mange and cattle plague,

Table 7. Number of anthrax cases in selected countries during the period 1923-1925 [28, 60]

\begin{tabular}{|c|c|c|c|}
\hline Country & Cases & Country & Cases \\
\hline Bulgaria & 10 & Poland & 202 \\
\hline $\begin{array}{c}\text { Free City of } \\
\text { Danzig }\end{array}$ & 1 & $\begin{array}{l}\text { Russia (Soviet } \\
\text { republics) }\end{array}$ & $31,668(1924-1925)$ \\
\hline Denmark & 12 & Switzerland & 8 \\
\hline Germany & 406 & $\begin{array}{l}\text { Serbia, Croatia, } \\
\text { Slovenia }\end{array}$ & $501(1925)$ \\
\hline Estonia & 8 & Czechoslovakia & 168 \\
\hline Finland & 4 & Hungary & 8 \\
\hline Italy & 6,536 & $\begin{array}{c}\text { United States of } \\
\text { America }\end{array}$ & 277 (1924-1925) \\
\hline Latvia & 6 & Uruguay & 235 (1924-1925) \\
\hline Lithuania & 21 & & \\
\hline Austria & 28 & & \\
\hline
\end{tabular}

occurred [282]. Surprisingly, there was no evidence of anthrax in the population, among domestic and military animals (horses, oxen, camels) or in the Turkish and German-Austrian troops during the war, at least not in available reports of German hygiene experts and physicians or in patient lists from hospitals on the Sinai and Palestine Front [283].

Anthrax in the civilian sector. During the period 19111919 , a total of 1,175 industrial cases of anthrax occurred in Germany. For the period 1910-1920, 405 industrial cases were reported in France and 714 in England [28].

The number of anthrax cases among humans and domestic animals dropped considerably in the German Reich during World War I (Table 6) as a result of the blockade established by the Entente Powers [284]. Between 1914 and 1919 , it decreased from 203 to 18 human cases and from 7,181 to 743 animal cases [285].

Among tanners, the number of cases fluctuated between $92,77,78,65$ and 56 during the period from 1910 to 1914 but only between 15, 7, 3, 12 and 6 during the period from 1915 to 1919 [60]. When the importation of animal products such as skins, hair and bone meal from endemic anthrax areas (India, China, The Balkans, African colonies) resumed in 1920, the number of anthrax cases increased again (Table 6).

Stricter veterinary police measures and import controls led to a decrease in the incidence of anthrax in the German civilian population from 252 cases in 1927 to 68 in 1934 and 49 in 1940 [60]. Where available, Tables 7 and 8 provide the

Table 8. Number of human anthrax cases in selected countries during the period 1923-1947 $([28,60])^{\mathrm{a}}$

\begin{tabular}{|c|c|c|c|c|c|c|c|c|c|}
\hline Country & $\begin{array}{l}1923- \\
1925^{b}\end{array}$ & $\begin{array}{c}1924- \\
1926\end{array}$ & $\begin{array}{c}1927- \\
1929\end{array}$ & $\begin{array}{c}1930- \\
1932\end{array}$ & $\begin{array}{c}1933- \\
1935\end{array}$ & $\begin{array}{c}1936- \\
1938\end{array}$ & $\begin{array}{c}1939- \\
1941\end{array}$ & $\begin{array}{c}1942- \\
1944\end{array}$ & $\begin{array}{c}1945- \\
1947\end{array}$ \\
\hline $\begin{array}{l}\text { USSR (Union of Soviet Socialist } \\
\text { Republics) }\end{array}$ & $31,668^{\mathrm{b}}$ & 15,435 & 15,950 & 4,542 & 2,569 & - & - & - & - \\
\hline Bulgaria & 10 & - & 465 & 856 & 1,026 & 914 & 624 & 709 & 1,525 \\
\hline Italy & $6536^{\mathrm{b}}$ & 2,288 & 2053 & 1,653 & 1,278 & 1,128 & 787 & 826 & 1710 \\
\hline Romania & - & - & - & - & 1,293 & 2,228 & 1,089 & 674 & 880 \\
\hline
\end{tabular}

\footnotetext{
aAnnual means.
}

${ }^{\mathrm{b}}$ Number of cases from 1924 to 1925 [28]. 
Table 9. Anthrax cases in different occupations (as percentages of all occupational diseases) [38]

\begin{tabular}{lccc}
\hline Occupations & Germany $(1910-1923) \%$ & England (1910-1922) \% & France (1910-1920) \% \\
\hline Farmers & 4.9 & 7.9 & - \\
Slaughterers & 34.4 & 5.8 & - \\
Knackers/renderers/skinners & 12.0 & 1.6 & - \\
Tanners & 36.9 & 21.3 & 64.7 \\
Wool workers & - & 47.5 & 26.7 \\
Bristle workers/brushmakers & 8.1 & 6.2 & 6.6 \\
Other occupations & 3.7 & 8.1 & 2.0 \\
\hline
\end{tabular}

numbers of anthrax cases for several countries that did not take part in World War II from the beginning.

In Russia according to Burgasov [279], there were at least 15,000 cases of human anthrax every year until 1917. In Tsarist Russia and later in the Soviet Union, more than 70,000 anthrax cases were reported for the period 1900-2003 [78]. An annual mean number of 31,668 human anthrax cases occurred in the population during the period 19241925 alone (Table 7) [28].

Similar to World War I, the blockade of imports of raw animal products from endemic areas, which was established by the Entente Powers, led to a decrease in the incidence of anthrax from 0.11 to $0.010,0.016,0.014,0.008$ and 0.004 cases per 10,000 population from 1939 to 1944 [28]. A similar decline in the incidence of anthrax was also reported for some of Germany's allies (Table 8). Where available, Table 8 provides the number of anthrax cases for several countries that did not take part in World War II from the beginning.

It is interesting to note that, before and after World War II, civil engineering activities involving soil disturbance such as the construction of roads and canals were not included in Western European statistics as causes of occupationally related cases of anthrax (Table 9).

\section{Anthrax in the troups during World War II (1939- 1945)}

Data on infectious diseases and wound infections from medical reports that are available from countries that participated in World War II, i.e. Germany, Britain, the United States and the Soviet Union, do not provide evidence of anthrax cases. Apparently, this zoonotic disease did not present a problem to the Wehrmacht (German armed forces) either before or during World War II. Accordingly, there are no articles on anthrax or references to 'anthrax,' ' $B$. anthracis' or 'anthrax bacilli' in Der Deutsche Militärarzt, which was the official journal of the German Medical Service from 1936 (Volume 1) to 1944 (Volume 9), or in the five volumes of Der Deutsche Sanitätsdienst 1921-1945 by Fischer.

Anthrax in animal populations during World War II (1939-1945). From 1939 to 1945, the German military used an estimated number of 2.75 million equids (especially horses and mules). Three quarters of the horses were employed on the Eastern Front alone [261]. Exact figures are unavailable since relevant statistical data were destroyed during the last months of the war [261].

From a veterinary perspective, anthrax obviously played no role during World War II and did not affect the animals that were used by the Wehrmacht.

This is noteworthy since combat activities took place in highly endemic countries with many anthrax foci (the Balkans, Italy, European parts of the USSR) (Tables 6 and 7).

The surveillance, prevention and control of epizootic diseases in the Wehrmacht was addressed in Army Veterinary Regulations 56 of 6 April 1932 (Heeresveterinärvorschrift - H. Dv. 56) including Epizootics Regulations (Seuchenvorschrift) in Annex 2, Wartime Veterinary Regulations 56/3 (Kriegsveterinärvorschrift - H. Dv. 56/3), and Wartime Veterinary Regulations 90 (Kriegsveterinärvorschrift - H. Dv. 90), which entered into force in 1940 [261].

Number 51 of the Wartime Veterinary Regulations provided, for example, that unit medical officers be notified in the event of anthrax cases. Enlisted personnel had then to be informed about routes of anthrax transmission. Animals known or suspected to be infected with anthrax and associated pieces of equipment, including drinking buckets, had to be isolated, the cleaning of affected animals was prohibited, and the stalls where the animals were kept as well as both adjacent stalls had to be disinfected and cordoned off [285]. The use of anthrax-infected carcasses was prohibited. These carcasses as well as discharges from the affected animals and contaminated objects (e.g. feed, fertiliser) had to be disposed of in a safe manner. In addition, the use of contaminated areas for grazing animals and hay production was prohibited [285].

The Wehrmacht Veterinary Service had 26 veterinary laboratory units (Veterinäruntersuchungsstellen) that were able to conduct laboratory tests for the diagnosis of animal diseases and the control of food of animal origin [261].

The Army Veterinary Laboratory Unit (Heeresveterinäruntersuchungsamt) alone analysed food of animal origin and performed serological and bacteriological tests of approximately $1,750,000$ samples in order to detect glanders, dourine and other (epizootic) diseases. There is, however, no evidence of samples that were positive for anthrax [261].

It should be noted that there was an order requesting Mobile Veterinary Laboratory Unit 509 to report in writing all positive test results indicative of anthrax, malleus 
(glanders) and piroplasmosis [261]. Bacteriological food inspections, however, were deficient because veterinary laboratory units were often locally unavailable.

Food safety was controlled in accordance with Army Veterinary Regulations 43a and applicable laws and regulations on meat inspections and food. The focus of food safety control measures was on the illegal slaughtering of animals since an increasing number of outbreaks of trichinosis and tapeworm infections were noted especially in Poland, the Soviet Union, and the Balkans [261]. Although many anthrax foci existed in these countries, anthrax apparently did not present a problem. In addition, carcass disposal facilities, rendering facilities and knackeries, which were legally required in Germany, were often absent in the occupied areas. As a result, animal carcasses were buried after usable animal materials, e.g. skins, animal meal, bone oil, horse skins, hides and hair, had been obtained in mobile rendering installations of veterinary companies [261].

Although these activities were associated with potential risks of exposure, no anthrax cases among military personnel were reported. This suggests that the processed animals had been free of anthrax.

Whether acts of sabotage led to relevant outbreaks of anthrax in occupied Poland is doubtful. For example, Rowecki, a Polish general, reported on 27 April 1941 that cattle had been infected with anthrax in four counties and in three towns [286].

In 1943, however, the Chief of Staff of the Wehrmacht Medical Service provided a list of actions that had been carried out in the General Government and included the following [287]:

"(1941-42): ... in Poznań ... anthrax bacteria were successfully used in horses in two stud farms."

"(August 1942): Forty-five boxes were seized at Lublin station; among other things, the boxes contained ... bottles, each of which filled with $200 \mathrm{ccm}$ of ... glanders bacteria or anthrax suspension."

It should be noted that there was a Department for Bacteriological-Toxicological Warfare in Poland before the German invasion [286]. This department had access to eight bacteriological laboratories and thus to anthrax strains that were suitable for use in acts of sabotage.

In spite of tens of thousands of individual cases of disease, there were no major outbreaks of feared epizootic diseases such as glanders, equine contagious pneumonia, equine viral arteritis, equine infectious anaemia, and mange in military horses because of extensive veterinary preventive and police measures including vaccinations and epidemiological investigations in theatres of war on the basis of data from the International Veterinary Office in Paris [261]. Military animals were mainly affected by strangles and contagious catarrh of the airways, pneumonia, fatigue as a result of overexertion and malnutrition, frostbite, and direct weapon effects [261].

No outbreaks of anthrax are mentioned in a monograph entitled Das deutsche Heeresveterinärwesen im Zweiten
Weltkrieg (The German Army Veterinary Service in World War II). This is confirmed by Betzler [261], who reported that "all other epizootics such as equine infectious anaemia, equine viral arteritis, rabies, ... anthrax etc. have not occurred."

It is highly probable that the strict implementation of the aforementioned regulations and directives relating to the extensive prohibition of transporting meat and other animal products and the import of live animals from occupied areas contributed to preventing the introduction of epizootic diseases, including anthrax, into Germany during the war [261].

Many clinical and epizootological documents and situation reports, however, were lost during the retreat from the fronts [261].

According to a draft version of Geschichte des Kriegsveterinärwesens 1939-1945 (History of the War Veterinary Service 1939-1945, Military History Research Office, p. 328), 1,580,000 animals were lost from 1 September 1939 to 31 August 1944. Exact numbers of cases and statistics on losses for specific (epizootic) diseases are not available. This applies also to epizootic diseases from September 1943 to April 1945 [261]. For this reason, there is no definitive information on the occurrence of anthrax in military animals of the Wehrmacht.

If Britain had dropped linseed cattle cakes in retaliation to an anticipated biological attack from Germany, a drastic deterioration in the epizootic situation would likely have occurred [136]. By 22 April 1943, five million cattle cakes, each filled with a lethal dose of (500 million) anthrax spores were ready for aerial drops over German farmland where cattle or sheep would eat them (Operation Aladdin). The use of this highly infective dry feed would have caused extensive livestock losses in Germany and - similar to the situation on Gruinard Island - may have contaminated agricultural land for many decades [136]. Appropriate protective measures prevented anthrax infections during the preparation of suspensions with high concentrations of spores and the packing of cattle cakes $[129,136]$.

Anthrax in military personnel. About 18.2 million members of the Wehrmacht and Waffen-SS took part in World War II. Of these, approximately 5.3 million died [288]. There is, however, no Medical Report for all years of the war so that definitive data on the total number of sick and wounded and the incidence of infectious diseases are unavailable.

Information can thus be obtained only from the unit medical records of the German Medical Service, according to which a total of 13,475,764 Field Army (Feldheer) and 9,135,722 Replacement Army (Ersatzheer) soldiers received medical care during the first four years of the war. According to a German Army Medical Report [289], there were $3,015,589$ wounded and 16,517,879 sick soldiers from 1 September 1939 to 31 August 1943.

The Field Army accounted for 2,100,511 sick soldiers and the Replacement Army for 1,292,754 sick soldiers 
during this period [290]. The main causes of disease were inflammation of the tonsils, colds, dysentery, malaria, scarlet fever, and diphtheria. According to Müller [263, 291], there were 175,570 members of the Field Army and 7,852 members of the Replacement Army who had "other communicable diseases" between 1939 and 1943. These diseases included rare zoonotic diseases, i.e. trench fever (five-day fever), Pappataci fever, mud fever, tularaemia, trichinosis, dengue fever, and relapsing fever. The author concluded that the number of reported cases of anthrax was too low to be included in the statistics.

According to Zimmer [292], medical treatment was most commonly provided for dysentery, cholera, typhus, typhoid fever, paratyphoid fever, trench fever, malaria, tuberculosis, diphtheria, scarlet fever, tularaemia, Pappataci fever, amoebic dysentery, Malta fever, and trichinosis. These findings were confirmed in a study on the role of consulting physicians of the German Army Medical Service from 1939 to 1945 [292]. There are no data on anthrax.

The 744,807 reported cases of diseases of the skin, appendages and subcutis included boils, inflammation of cellular tissue and sweat glands, abscess formation, and similar conditions, but not anthrax [263]. This zoonosis obviously played such a minor role in the Medical Service of the Wehrmacht that no special vaccinations were required [293].

In the reports that were submitted by consulting surgeons and physicians during World War II, there was no mention of anthrax for the period 1939-1944 [290, 292, 294]. The main causes of wound infections were gas oedema and gangrene caused by anaerobic spore-forming organisms as well as phlegmons and pus formation caused by staphylococci and streptococci, and wound diphtheria [290, 295]. Knofloch [295] distinguished four groups of bacteria that caused wound infections:

Pyogenic bacteria, including different forms of Streptococcus spp. and Staphylococcus aureus

Haemolytic bacteria, Micrococcus tetragenus in rare cases Anaerobic bacteria, gas-forming infections caused by Welch-Fraenkel bacilli, Bacillus novyi, Bacillus histolyticum, blackleg bacilli, tetanus bacilli, fusiform bacteria Putrid infections caused by putrefactive bacteria

Mixed infections with B. coli, B. pyocyaneus, hay bacilli, and others.

Single cases of tetanus, tularaemia and suspected glanders were reported [290].

It should be noted that the idea of using anthrax spores for military purposes dates back to as early as the 1920s. According to British intelligence in 1939, Germany was allegedly working on attempts to "infect" grenades with anthrax cultures. If anthrax organisms had entered wounds, the mortality rate would have been $95 \%$. This information, however, was found to be incorrect since Hitler always ruled out the use of biological weapons and the responsible German agencies refused to perform such work [129, 287].

Documents relating to the French biological weapons programme, which fell into the hands of the German occupiers in 1940, revealed that there had been theoretical considerations "to infect projectiles with bacteria ... in order to make the effects of projectiles more malicious". The plan was to place glass ampoules filled with anthrax and other organisms in bombs and rifle grenades in order to make these devices "infectious". In field trials that were conducted in 1939, for example, spore-contaminated fragments were produced through the explosion of grenades that had been filled with $B$. pseudoanthracis spores. Previous experiments on guinea pigs had shown that such projectiles could cause lethal infections [129, 287].

From a military medical perspective, zoonotic communicable diseases were of no relevance [296]. No mention of anthrax was made in a manual on internal medicine [297], in a manual on the special prognosis of internal diseases [298] or in a book on the occurrence and control of wartime epidemics [299]. Schloßberger [299] regarded especially plague, cholera, typhoid fever, dysentery, typhus, and epidemic hepatitis as infectious diseases that were typically encountered in times of war.

In a manual entitled Wehrhygiene (Military Hygiene), anthrax was briefly described as a "rare disease" and "soilborne epidemic", which, however, was "of almost no relevance" to the Wehrmacht $[300,301]$.

This was probably the reason why there were no special rules for the construction of field fortifications involving the movement of soil in front sectors known to be anthrax foci $[302,303]$. Potential risks of infection for engineers were associated only with gas oedema (mine injuries contaminated with soil) and tetanus (wood splinters) [302].

From 1 July 1941 to 18 February 1943, a total of 102,843 autopsies were carried out and demonstrated 19,291 aerobic wound infections (including wound diphtheria) and 6,053 anaerobic wound infections [290]. The most common causes of death were typhoid fever, parathyphoid fever, dysentery, cholera, influenza, typhus, and Weil's disease. A total of 9,664 deaths were attributable to "other" causes of infection [290]. It is no longer possible to determine whether this figure includes anthrax infections.

According to unit medical records, 175,000 cases of "other communicable diseases" (fourteen infectious diseases other than typhoid fever, paratyphoid fever, dysentery, cholera, smallpox, and typhus) were reported for the Field Army and 7,852 cases for the Replacement Army.

Owing to a lack of concrete data, a statistical evaluation of approximately 12,000 further patients in this category was not possible. Among them were a few patients with Bang's disease, yellow fever and anthrax [291].

The preventive health care that the Wehrmacht provided in the occupied areas consisted of preventing and limiting typical wartime epidemics in the civilian population [304]. Anthrax played no major role. This applied to war missions of the Wehrmacht in subtropic and tropic areas, too [305].

For this reason, it is not surprising that anthrax was not addressed in articles on infections in the Wehrmacht, which were published in the journals of the Medical Service of the German armed forces Wehrmedizinische Mitteilungen, 
which became the Wehrmedizinische Monatsschrift in 1966 [291, 306-310].

It should be noted, however, that unit medical records and statistics on communicable diseases - similar to documents of the Army Veterinary Service - were lost or destroyed in the last two years of the war during the retreat [263].

During World War II, the U.S. military reported approximately 6 million cases of infectious and parasitic diseases, including 1,250,846 sexually transmitted diseases, $4,196,093$ respiratory infections, 403,689 cases of malaria, 1,193 cases of typhoid and paratyphoid fever, 83,371 cases of dysentery, and 22,032 cases of food poisoning [311]. No cases of anthrax were reported.

The same applies to the British General Hospitals in Northwestern Europe, which provided medical treatment to 28,048 patients between July and December 1944 [312].

Microbiological analyses of samples from 37 wounded soldiers from Normandy, Belgium and Holland identified Clostridium bacteria, coliform bacteria and staphylococci but no bacilli [312]. Green [157] reported that there were no cases of anthrax in the armed forces of the United Kingdom during World War II. One likely reason for this was the early administration of penicillin for the management of wounds. In the British Army, penicillin or penicillin sulphonamide powder was applied to fresh war wounds in a preventive manner in 1943 [312]. As of July 1944, the British and U.S. armed forces had unlimited quantities of penicillin so that the early preventive administration of penicillin to wounded soldiers became the method of choice $[311,312]$.

According to Czickeli [241], fourteen Romanian soldiers died in 1942 from a cholera-like disease that was later found to be intestinal anthrax. Later epidemiological and bacteriological investigations confirmed that they had eaten cooked meat of a sick sheep.

In an earlier incident, an explosive outbreak which occurred at a railroad station in Yaroslavl and lasted from 6 to 17 July 1927, showed how difficult it was to diagnose anthrax only on the basis of clinical signs and symptoms. Twenty-seven workers developed acute symptoms indicative of influenza or mild gastroenteritis and within a short time died from what was found to be intestinal anthrax [313]. This epidemic was probably not a unique event during prewar times. Only on the territory of the Soviet Union, 31,668 human anthrax cases occurred between 1924 and 1925 (Table 6) [28]. In spite of the existence of many anthrax foci and anthrax outbreaks in the Eastern theatre of war, Red Army Medical Service reports provide no evidence of anthrax cases in the military, in the Soviet civilian population, or in military and civilian animal populations. It should be noted, however, that there were no official reports of anthrax cases from 1936 to 1947 (see Table 7).

The only information on anthrax infections during the war was provided by Viskovskiy and Rozhdestvenskiy [314] in Volume III of the Soviet Medical Service Report. At the time of the Soviet attack on Romania in August 1944, the epidemic and epizootic situation was unsatisfactory when it came to anthrax (see Table 7) and was thus a threat to the armed forces [280]. As a result of a low level of veterinary police surveillance, this zoonotic disease was common in local animals. Accordingly, anthrax morbidity rates in humans were relatively high and varied between 0.5 and 1.6 cases per 10,000 population from 1931 to 1940 (mortality rate: $5.1-8.7 \%$ ) and between 0.2 and 0.5 cases per 10,000 population from 1941 to 1945 (mortality rate: 5.4-9.4\%) [280, 314].

For this reason, the Red Army Medical Service provided human vaccinations against anthrax in particular for cavalry units from July to August 1944. A total of 90,000 Army soldiers was immunised with a live non encapsulated spore vaccine (called STI), which had been developed by N. N. Ginsburg and A. I. Tamarin in 1942. As a result, anthrax outbreaks were prevented in vaccinated populations [280, 314]. This preventive measure proved valuable also later in the war when combat took place in Hungary, where a large number of anthrax cases were reported among the local population in 1944 [314].

\section{Occurrence of anthrax after 1945}

Regional and local wars. During the Korean War, 67\% of all war wounds were contaminated with anaerobic organisms. Bacterial contamination and infections were an "integral part" of all war wounds [315]. Examinations of wounded soldiers showed, that, similar to the situation in World Wars I and II, besides of pieces of clothing and bone fragments different bacterial species were introduced into wounds via soil particles $[316,317]$. The majority of these bacteria were anaerobic spore-forming organisms, micrococci and streptococci whose toxins enabled them to enter tissue rapidly [315]. In $46 \%$ of the cases, the injuries were found to be contaminated with Clostridium spp. during primary debridément [316].

Bacillus spp. were detected in fresh wounds in $9.5 \%$ of 42 patients in the summer of 1952 and in $61.6 \%$ of 112 patients in the winter of 1952 [271]. B. anthracis, however, was not explicitly mentioned. Early debridement and the administration of penicillin and streptomycin led to a drastic reduction in the number of bacteriologically confirmed cases.

Other military medical reports on infectious diseases and wound infections in armed forces that participated in the wars in Korea and Vietnam do not contain data on anthrax [316, 318-323]. Between 1965 and 1968, approximately 500,000 U.S. troops were deployed to Vietnam. From 1966 to 1967, there were approximately 217,407 admissions to medical treatment facilities. Of these, approximately 70\% were for communicable diseases [323]. Diarrheal diseases, respiratory diseases, malaria, skin diseases, and fevers of unknown origin accounted for $60 \%$ of these cases [323].

Palinkas et al. [322] reported that the total number of first hospitalisations among U.S. Marines was 192,654 in Vietnam between 1965 and 1971. Of these, 31,777 received treatment for infective and parasitic diseases and 16,113 for diseases of the skin and subcutaneous tissue. 
According to Hardaway [324], 3.9\% of the 17,726 U.S. soldiers who were wounded in Vietnam had acute wound infections. Initial wound management consisted of debridément in $80.5 \%$ and the topical application of antibiotics in $70 \%$. Wound infections were present in $7.8 \%$ of the 24,742 soldiers who were hospitalised for maxillofacial injuries in 1968 [325]. In none of these cases did microbiological tests detect $B$. anthracis.

Between 1 January 1967 and 31 March 1968, Matsumoto et al. [319] analysed 1,531 cultures from wounds that had been swabbed immediately after U.S. soldiers had been wounded in Vietnam. Whereas 204 cultures showed no growth, 1,327 were positive. Of the 17 identified bacterial species, S. aureus, Pseudomonas aeruginosa and Escherichia coli were most commonly seen. Bacillus species, which are typical soil organisms, were not detected.

Similar results were reported by Kovaric et al. [326] who conducted a bacteriologic survey on 85 Vietnamese and 25 American soldiers who were treated for war wounds in a hospital in Vietnam from May to June 1967. No Bacillus species were found in the 78 samples that showed bacterial growth. Among the organisms that Tong [327] isolated from 63 fresh wounds of 30 injured U.S. Marines were commensals of human skin (Staphylococcus epidermidis) and organisms that are commonly found in moist environments such as Mimea-Herellea (probably Acinetobacter spp.), Enterobacter, and B. subtilis.

The immediate topical application of antibiotics made it possible to extend the infection-free period prior to debridément and to effectively reduce wound infection rates [318, $326,328]$. This would explain why Bacillus species were less frequently isolated from fresh wounds in the Vietnam War although these organisms were ubiquitous in soil. Matsumoto et al. [318], for example, detected apathogenic Bacillus species, such as B. subtilis, B. mycoides, B. cereus and B. pumilus, but no causative agents of anthrax in soil samples from areas where U.S. ground forces were engaged in combat.

In the Yom Kippur War in 1973, 22\% of the 420 soldiers who had sustained injuries (mostly from high-velocity missiles) or burns were found to have developed an infection although they had received penicillin on the battlefield within 30-60 minutes after injury [329]. Anthrax infections were not reported.

Unusual epidemics of anthrax occurred in the Rhodesian Bush War between 1978 and 1980. Approximately one million cattle were reported to have died [37]. The epidemic involved a total of 10,738 human cases with 182 fatalities. All of the cases were among blacks living in rural areas known as Tribal Trust Lands, now known as Zimbabwe [37]. White settlers, their livestock, and members of the Rhodesian Army were not affected. There is some suspicion even today that this was a biological attack involving anthrax spores which the Rhodesian Army targeted at animals belonging to the black population [37]. In the 1970s, the white government maintained a limited biological weapons programme at the University of Rhodesia and planned to place anthrax spores and other organisms in cigarettes and chocolate in order to eliminate leaders in the liberation war [37, 330].
One reason for the massive spread of anthrax at that time was probably that the rural medical and veterinary system had collapsed and veterinary control measures were no longer provided. People were forced by hunger and malnutrition to eat sick animals that were slaughtered out of necessity and to use infected animal products. Safe drinking water was extremely scarce for both humans and animals [331].

All three forms of anthrax were observed [37, 238]. Clinically, cutaneous anthrax acquired by direct contact with sick animals and infectious animal tissue was the predominant manifestation of illness [37]. Other causes of infection were the bites of blood-feeding insects (especially stable flies and horseflies) and scratching with fingernails that harboured infectious blood or contaminated soil particles [37]. This latter route of transmission had already been described by Lindtrop in 1927 [28].

Wilson et al. [238] reported that the epidemic in the Tribal Trust Lands lasted until December 1984 and caused 17,199 human cases including over 200 fatalities. The manifestation rate was $0.43 \%$ in the overall Tribal Trust Land population of approximately four million or $2.1 \%$ in the rural farming population of 800,000 [238]. According to Fleischer (personal communication 2013), who provided treatment to more than 600 patients with cutaneous anthrax at that time, all patients were known to have had contact with animals. To his knowledge, there were no cases of infection caused by exposure to possibly contaminated soil.

During the Bosnian War, 4,545 patients were treated at the university hospital of Osijek from May 1991 to November 1992. Most of their injuries had been caused by explosive devices, firearm bullets, and blunt objects. Superficial aerobic wound infections exclusively were seen in $1.7 \%$ of patients [332].

Of the nearly two million personnel assigned to military service in Iraq and Afghanistan between 2005 and 2009, those who were wounded sustained more than 29,000 injuries. Improvised explosive devices (IED) caused $74 \%$ of the injuries [333]. From April 2010 to October 2013 alone, 902 of 15,504 Polish ISAF members underwent inpatient treatment for injury or sickness [333].

None of the above-mentioned or other military medical publications on Operation Desert Shield and Operation Desert Storm in Iraq, Operation Iraqi Freedom, Operation Restore Hope in Somalia, or Operation Joint Guard in Bosnia provided evidence of anthrax cases [334, 335]. The same applies to military operations of the armed forces of the United Kingdom from 1994 to 2014 [157].

Zouris et al. [336] analysed the records of 13,071 casualties of the U.S. Marine Corps and the U.S. Army during the Operation Iraqi Freedom Major Combat Phase (OIF-1, spring of 2003) and Stability Phase (OIF-2, spring of 2004) on the basis of the International Classification of Diseases (ICD-9). Of the 13,071 casualties, 3,263 were wounded in action (WIA) casualties and 9,808 were disease and nonbattle injury (DNBI) casualties [336]. The percentage of patients with infectious diseases ranged between 0.9 and $2.1 \%$. Data on the spectrum of infectious agents are not available. 
Aerobic cultures that were obtained immediately after injury from 61 separate wounds from 49 casualties in the spring of 2004 and that were analysed for the detection of aerobic bacteria provided no evidence of Bacillus species [337]. The bacteria most commonly isolated were skincommensal organisms, i.e. different coagulase-negative staphylococci (CNS) species (32 cases) and S. aureus (4 cases).

Similar results were reported by Yun et al. [338] who retrospectively analysed bacterial cultures obtained from U.S. troops in Iraq between August 2003 and July 2004. A total of 176 isolates were recovered from U.S. patients (102 wound, 10 blood, 24 sputum, and 40 urine samples). The predominant bacterial isolates were coagulase-negative staphylococci (CNS) (34\%), S. aureus (26\%), and Streptococcus species $(11 \%)$. Wounds were apparently contaminated with soil-borne bacteria only in rare cases. In both studies, B. anthracis was not identified.

Anthrax in armed forces of post-war Germany. Anthrax played only a minor role in post-war Germany. In the former German Democratic Republic (GDR), a mere 20 cases were reported from 1951 to 1958 [60]. Surprisingly, Sinnecker [339] did not deal with the occurrence and epidemiological features of anthrax in his monograph on general epidemiology whereas he addressed several other zoonotic diseases such as tularaemia, rickettsial diseases and salmonellosis.

In the Federal Republic of Germany, 77 anthrax cases were reported between 1949 and 1957. Of these, 30 cases were industrial anthrax [60]. The Robert Koch Institute registered the last case of cutaneous anthrax in 1994 and six cases of injection anthrax from 2009 to 2012 [340].

During the Cold War, no anthrax cases were recorded in the National People's Army (Nationale Volksarmee) and the Border Troops (Grenztruppen) of the GDR. At least, no case reports were published in the Zeitschrift für Militärmedizin, the journal of military medicine of East Germany (volumes 1958-1990).

Clinical aspects of anthrax and B. anthracis as a potential biological agent were briefly discussed only in a volume on military internal medicine (Innere Militärmedizin). It was published in 1984 as part of a series of manuals on military medicine (Militärmedizin). No information on anthrax, however, was available in the volumes on preventive health protection (Vorbeugender Gesundheitsschutz) (1972) and military hygiene and field epidemiology (Militärhygiene und Feldepidemiologie) (1987).

The analysis of European natural foci of zoonotic diseases, such as anthrax, was a major research topic among the military medical services of the Warsaw Treaty member states from 1970 to 1988 [341]. This included the occurrence of active anthrax soil foci on the European territory of the former USSR, which were predominantly found in marshes, black-coloured soil (chernozem), and alluvial soil [341]. The highest morbidity rates were seen in large cattles in the north western and in sheep and goats in the southern Soviet Union.

Anthrax soil foci and stationary anthrax sites that were unfavourable to livestock (stationary unfavourable sites -
SUS) were classified as active, relapse active or non-active. Active and relapse active sites (approximately $20-25 \%$ of all SUS) were defined as places where anthrax occurred in animals at periodic intervals (every five to ten years) [341].

The risk of anthrax was assumed to rise in disaster settings, e.g. earthquakes or floods, and military exercises or wars [138].

Likewise, a higher anthrax risk was believed to be associated with the building of trenches, shelters or camps, the processing of dead animals and the slaughtering of sick animals in contaminated areas. Strict compliance with veterinary, occupational and food hygiene regulations and the vaccination of persons at a risk of occupational exposure to anthrax were therefore required [138]. For this purpose and in order to protect soldiers against potential biological attacks with anthrax spores, the Soviet live vaccines STI and GNKI prepared from the attenuated unencapsulated Shuya15 strain [38] were available to the armed forces of the Warsaw Treaty (Pact) member states in a lyophilised state. The East German armed forces, for example, stored sufficient amounts of vaccines for its personnel in the Central Supply Depot near Spechthausen (Brandenburg) until 1990.

A search of the journals of the German military medical service (Wehrmedizinische Mitteilungen, Wehrmedizinische Monatsschrift and Wehrmedizin, which became Wehrmedizin und Wehrpharmazie in 1969) showed that in the Bundeswehr (German armed forces), too, no cases of anthrax have occurred since its founding in 1956 until to the present day. This applies to both the Federal Republic of Germany and anthrax endemic regions to which the Bundeswehr has been deployed. Latter include e.g. Turkey, Somalia, the Balkans, Afghanistan, Mali, Syria, Iraq and Sudan, where German troops took part in UN missions, disaster relief and NATO operations [282, 334, 335].

Frickmann et al. [342] analysed the infectious diseases for which military personnel who took part in the European Union Training Mission in Mali (EUTM Mali) sought medical care from 2013 to 2017. The total number of medical consultations was 9,805 . The majority of infectious diseases were gastrointestinal and respiratory infections without pulmonary or systemic complications. There was no evidence of anthrax infections.

As a rule, military surgeons of the Bundeswehr Medical Service assume all gunshot injuries to be contaminated and to require surgical debridément, open wound management, and single-shot antibiotic therapy [343]. On the basis of this approach, wound infections caused by micro-organisms that are introduced into wounds are extremely rare.

The prevention of zoonotic diseases in the Bundeswehr is an integral part of preventive health care that is based on the German Animal Health Act (Tiergesundheitsgesetz), the Regulation on Notifiable Epizootic Diseases (Tierseuchenanzeigeverordnung), the German Protection against Infection Act (Infektionsschutzgesetz), and the Food Law (Lebensmittelgesetz). In accordance with this system of rules, suspect cases and clinical cases of anthrax and deaths from anthrax are notifiable upon suspicion in animals and notifiable upon diagnosis in humans. 


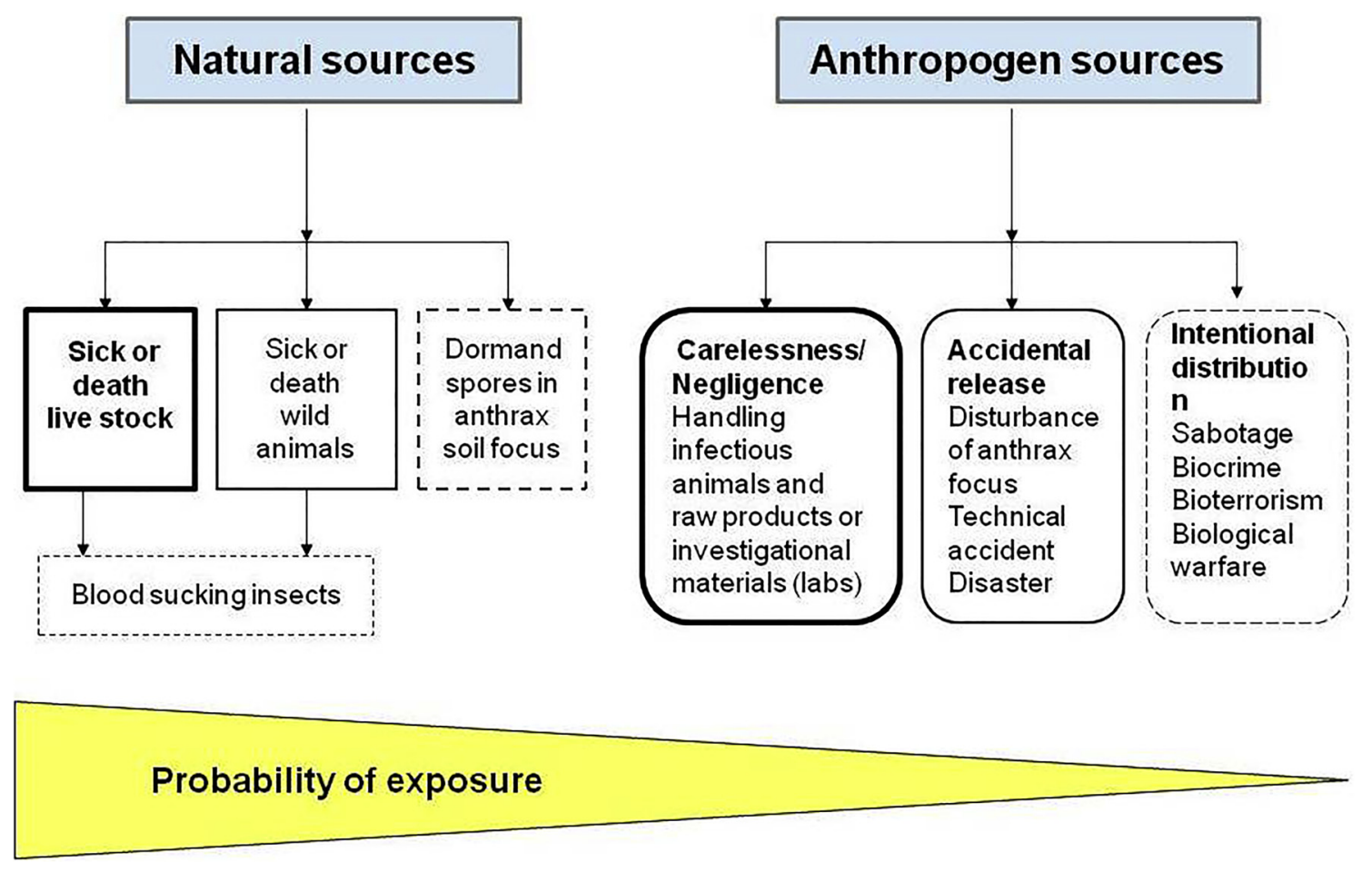

Fig. 5. Sources of contamination of the environment with spores of B. anthracis

The Veterinary Service of the Bundeswehr is responsible for the surveillance of epizootic and zoonotic diseases and the analysis of food, animal, environmental and water samples both in Germany and during deployments abroad [344]. A major objective is to prevent the introduction and spread of epizootic diseases during the redeployment of personnel and material. Further details are specified in Number 503 of Type A1 General Publication (Zentralvorschrift) A1-843/0-4011: "Animals, animal parts and objects that can carry infectious substances must not be imported." These requirements are translated into military orders during deployments and military personnel are informed in accordance with Annex 8.3 of the aforementioned General Publication (personal communication with Schotte, 2018).

But, there is a lack of historical data on past or present anthrax outbreaks in endemic areas of deployment as a result of missing or incomplete reports to the OIE and a large number of unreported cases (personal communication with Schotte, 2018). For this reason, it is difficult to assess the probable risk of infection objectively and to determine appropriate preventive measures. Such measures would be necessary only if an outbreak occurred among animals in deployment or assembly areas of military personnel.

When military personnel are deployed to endemic anthrax areas, they receive relevant information on nations and, if required, are informed about risks associated with animal products of unknown origin, e.g. meat, sausages, leather products or shaving brushes (personal communication with Buchner and Morwinsky, 2018).

In Germany, activities involving soil disturbance or the construction of canals or other structures are subject to the
Occupational Safety and Health Act (Arbeitsschutzgesetz), the Biological Agents Ordinance (Biostoffverordnung) and the Accident Prevention Regulations (Unfallverhütungsvorschriften) of the responsible professional associations. These provisions also apply to the Bundeswehr. Before special engineer units perform construction work or other activities involving soil disturbance, a hazard analysis is conducted in order to assess possible health risks caused, for example, by explosive ordnance, noxious chemical substances (heavy metals), or hantaviruses. Special attention is paid to exposure to dust contaminated with faeces and the associated potential risks of skin and airway infection or irritation during military operations abroad (personal communication with Densow, 2018). Potential exposure to soil-borne anthrax spores is not specifically mentioned.

\section{CONCLUSIONS}

Apart from the relatively low infectivity for humans, there are a number of factors that may explain why only very few cases of soil associated anthrax in humans were registered $[28,40,49,61,156,157,209,345-349]$ :

Small size and number of active anthrax soil foci, and animals that died of anthrax (depending on the season and weather conditions) in an endemic combat area, and thus a low probability of the release of spores and exposure in association with combat situations

"Dilution" and distribution of spores in anthrax soil foci by agricultural activities and decrease of spore concentration by antagonistic soil microbial activities 
"Dilution" of spores as a result of the impact of bombs, grenades or mines when large amounts of soil from different layers are blasted into the air and mix with spores Thermal inactivation of spores by explosions

Inactivation of free deposited spores by UV light of sun Attachment of spores to the soil matrix (e.g. clay, bentonite, humus particles) and formation of large complexes with soil and dust particles preventing inhalation in deeper air ways

Number of spores on or in contaminated environmental media too low to cause infection

It should not be underestimated, however, especially during World Wars I and II, the incidence of anthrax in enzootic areas decreased among domestic animals as a result of the reduction of animal populations (combat-related deaths and injuries, diseases, confiscation of animals by occupiers, mass slaughtering of animals as a result of an increased need for meat among soldiers and the population, shortage of feed, less breeding, and others).

Moreover, the import and use of animals and raw products from endemic areas were restricted for several years because of blockades.

As a result, there was a decrease in the incidence of agricultural and industrial anthrax cases and probably in the contamination of soil and waters with spores since the processing of infected raw materials was almost completely discontinued.

Weekly reports by the World Health Organization (WHO) and the World Organisation for Animal Health [164] show that active anthrax foci exist in some regions of deployment. Before military contingents are deployed to such regions, relevant information must be obtained although the risk of infection through soil or water potentially contaminated with spores appears to be extremely low (Fig. 5). This precaution is justified since former Commonwealth of Independent States (CIS) member states continuously monitor the epizootic situation (e.g. number, location and activity) of anthrax foci and have established special biosafety rules for the use of these sites or SUS.

Health risks after contact with soil contaminated by infectious carcasses, blood or tissue or after exposure to infected raw animal material or infected animal products, however, cannot be ruled out and should be included in an epidemiological assessment of the situation in an endemic area of deployment.

Under present mission conditions, anthrax as a zoonotic disease has no military medical impact [351]. Nethertheless, military personnel must be informed of potential infection risks in highly endemic areas of deployment where the carcasses of animals that died of anthrax are not buried appropriately and the organs and tissues of animals infected with anthrax are processed or otherwise used.

Soil, buildings, sewage reservoirs and land-near water bodies affected by wastewater discharges can be assumed to be associated with a low probability of spore contamination if infected animal skins from endemic regions have been processed at these sites in the past.
Anthrax spores are likely limited to the vicinity of tanneries, storage facilities for animal products, slaughterhouses, rendering facilities, knackeries, animal burial sites and animal graves if they are not transported via soil water to other areas by heavy rain. If wells, roads or canals must be constructed at these sites or other activities involving the movement of soil must be performed and if there is evidence of potential contamination, a biological hazard analysis must be performed. The same applies to activities during which the soil is disrupted and carcasses or parts of animals or animal processing wastes are dug up. In these cases, a higher risk of exposure must be assumed. If justified, microbiological investigations can be necessary to detect spores in soil.

It should be noted that the increase in mean global temperatures in the northern hemisphere in the 21st century can favour the reactivation and spread of spores of $B$. anthracis [352]. The anthrax situation among domestic and wild animals and the population in endemic areas of deployment should therefore be analysed prospectively and, where necessary, actively clarified and monitored during deployment. For this purpose, available GEOSYS data and registers of anthrax soil foci can be used, or specific registers should be established on the basis of country reports that are submitted to the OIE and WHO. When anthrax cases occur among animal populations in endemic areas of deployment and are likely to lead to environmental spore contamination, soil areas or objects should be microbiologically tested for anthrax prior to their being used for military purposes. Isolates of $B$. anthracis should be genotyped with a view to differentiating between wild-type and vaccine strains. Knowledge of the epizootic or epidemic background and the characteristics of endemic $B$. anthracis strains is particularly important in the case of unusual anthrax outbreaks. Based on this knowledge, it is possible to determine whether an outbreak is a natural or man-made incident (e.g. a bioterrorist attack) and whether it has been caused by a strain that is atypical for a region.

For this purpose, there should be a continuous exchange of information and data between the medical services of allied nations using, for example, the NATO Deployment Health Surveillance Capability (DHSC). In addition, it is important to ensure interdisciplinary cooperation within the medical service (veterinary service, occupational safety and health protection, biological medical defence, medical intelligence, etc.) and with CBRN (chemical, biological, radiological, nuclear) defence forces, the geoinformation service, and military units (e.g. special engineer units).

If residual animal material (e.g. skins, fur, hair or bristles) is detected after attacks involving the use of improvised explosive devices (IEDs) in endemic areas, it should be examined for the presence of anthrax spores and casualties should be monitored for signs of infection (Fig. 5).

As a result of the rarity of anthrax in Central Europe, physicians are no longer completely familiar with the clinical picture of the disease. There is a risk that single cases or index cases will be detected too late in natural outbreaks or bioterrorist attacks. For this reason, it is important to know 
the routes of transmission, the forms of infection, clinical signs and symptoms, and the differential diagnosis of anthrax and to identify potential sources of exposure on the basis of past medical history. If a severe case of anthrax occurs despite precautions, a multi-disciplinary approach to diagnosis and intensive medical care is imperative.

So far there is no scientific evidence proving for soilborne anthrax in military animals and soldiers even in case of intensive exposure during heavy disturbance of soil structure in known endemic areas.

In summary, the few available reports on civilian anthrax cases after exposure to soil-borne or dust-borne spores suggest that this route of transmission is of very low epidemiological significance. That is supported by the fact that the sources or vehicles of infection could not be ascertained in many of the cases described.

The literature review presented here shows that the risk of infection through soil or water potentially contaminated with spores is extremely low in anthrax regions (Fig. 5). In highly endemic areas of deployment, however, carcasses of animals that died of anthrax are often simply buried and infected animals and animal material are processed and otherwise used. For this reason, there is a certain risk of infection in the case of contact with soil from recent burial sites of infected animals and with products made of infected or contaminated raw animal material. Such health risks should be included in an assessment of the epidemiological situation in any endemic area of deployment and military personnel should be informed accordingly.

Funding sources: No financial support was received for this study.

Authors' contribution: EJF, WB, UL, and HF jointly performed the literatature review for with work. EJF wrote the article. All authors jointly optimized and reviewed the manuscript.

Conflict of interest: Nothing to declare.

\section{ACKNOWLEDGEMENTS}

Barbara Isenberg (Bundessprachenamt) is gratefully acknowledged for translating the manuscript to English.

\section{ABBREVIATIONS}

$\begin{array}{ll}{ }^{\circ} \mathrm{C} & \text { degree centigrade } \\ \text { B. } & \text { Bacillus } \\ \text { BIG } & \text { Prof. Burmeier Ingenieurgesellschaft mbH } \\ \text { canSNP } & \text { canonical single nucleotide polymorphism } \\ \text { CBRN } & \text { chemical, bacteriological, radiological, nuclear } \\ \mathrm{CIS} & \text { Commonwealth of Independent States } \\ \mathrm{cm} & \text { centimetre } \\ \mathrm{CNS} & \text { coagulase-negative staphylococci } \\ \text { DHSC } & \text { Deployment Health Surveillance Capability } \\ \text { DNBI } & \text { disease and nonbattle injury } \\ \text { EF } & \text { oedema factor }\end{array}$

$\begin{array}{ll}\text { e.g. } & \text { for example } \\ \text { EUTM } & \text { European Union Training Mission } \\ \text { Fig } & \text { figure } \\ \text { GIS } & \text { geographic information system } \\ \mathrm{km}^{2} & \text { squre kilometres } \\ \text { ICD } & \text { International Classification of Diseases } \\ \text { IED } & \text { improvised explosive device; } \\ \text { LF } & \text { lethal factor } \\ \mu \text { m } & \text { micrometer } \\ \text { NATO } & \text { Northern Atlantic Treaty Organization } \\ \text { OIE } & \text { Office Internationale des Epizooties } \\ \text { OIF } & \text { Operation Iraqi Freedom } \\ \text { PA } & \text { protective antigen } \\ \text { SAA } & \text { stationary anthrax-affected area } \\ \text { SNP } & \text { single nucleotide polymorphism } \\ \text { SUS } & \text { stationary unfavourable by anthrax sites } \\ \text { TNF } & \text { tumour necrosis factor } \\ \text { U.S. } & \text { United States } \\ \text { WHO } & \text { World Health Organization } \\ \text { WIA } & \text { wounded in action }\end{array}$

\section{APPENDIX A. SUPPLEMENTARY DATA}

Supplementary data to this article can be found online at https://doi.org/10.1556/1886.2020.00008.

\section{REFERENCES}

1. Hugh-Jones M, de Vos V. Anthrax and wildlife. Rev Sci Tech Off Int Epiz. 2002;21:359-83.

2. Malkhazova SM, Mironova VA, Kotova TV, Shartova NV, Orlov DS. Natural-focal diseases: mapping experience in Russia. Int Health Geogr. 2014;13:21.

3. Kolonin GV. Evolucija sibirskoj jasvy. Soobchenie. II. Istorija rasprostranenija bolezni i formirovanie nozoareala. Zh Mikrobiol Epidemiol Immunobiol. 1971;48:80-4.

4. Cherkasskiy BL. Epidemiologija zoonozov. In:Pokrovskij VI (pod red.). Rukovodstvo po zoonozam. Leningrad: Medicina; 1983. pp. 19-38. [Russian].

5. Makarov VV, Bryco NI. World nosoaeral of anthrax. Epidemiol Infect Dis: Actual Probl. 2011;2:13-7. [Russian].

6. OIE, FAO, WHO. Guidelines for the surveillance and control of anthrax in humans and animals. 4th ed. Geneva: World Health Organization; 2008, http://www.who.int/csr/resources/ publications/AnthraxGuidelines2008/en/index/html, http://www. who.int/csr/resources/publications/anthrax_web.pdf, last accessed 20 March 2020.

7. Böhm R. Bacillus anthracis. In: Blobel T, Schließer T, editor. Handbuch der bakteriellen Infektionen bei Tieren, 1st ed. Jena: VEB Gustav Fischer; 1985, vol. V, p. 17-89.

8. Koehler TM. Bacillus anthracis physiology and genetics. Mol Aspect Med. 2009;30:386-96.

9. Keim P, Gruendike JM, Klevytska AM, Schupp JM, Challacombe J, Okinaka R. The genome and variation of Bacillus anthracis. Mol Aspect Med. 2009;30:397-405. 
10. Antwerpen M, Beyer W, Bassy O, Ortega-García MV, CabriaRamos JC, Grass G, Wölfel R. Phylogenetic placement of isolates within the Trans-Eurasian Clade A.Br.008/009 of B. anthracis. Microorganisms. 2019;7:689.

11. Pilo P, Frey J. Pathogenicity, population genetics and dissemination of Bacillus anthracis. Infect Genet Evol. 2018; 64:115-25.

12. Derzelle S, Girault G, Kokotovic B, Angen $\emptyset$. Whole genomesequencing and phylogenetic analysis of a historical collection of Bacillus anthracis strains from Danish cattle. PloS One. 2015;10: e0134699.

13. Girault G, Thierry S, Cherchame E, Derzelle S. Application of highthroughput sequencing: discovery of informative SNPs to subtype Bacillus anthracis. Adv Biosci Biotechnol. 2014;5:669-77.

14. Derzelle S, Thierry S. Biosecurity and bioterrorism: biodefense strategy, practice, and science. Vol. 11. Suppl. 1, Mary Ann Liebert, Inc.; 2013. https://doi.org/10.1089/bsp.2013.0003.

15. Collier RJ. Membrane translocation by anthrax toxin. Mol Aspect Med. 2009;30:413-22.

16. Duesbery NS, Webb CP, Leppla SH, Gordon VM, Klimpel KR, Copeland TD, Ahn NG, Oskarsson MK, Fukasawa K, Paull KD, Vande Woude GF. Proteolytic inactivation of MAP-kinase-kinase by anthrax lethal factor. Science. 1998;280:734-7.

17. Vitale G, Pellizzari R, Recchi C, Napolitani G, Mock M, Montecucco C. Anthrax lethal factor cleaves the N-terminus of MAPKKs and induces tyrosine/threonine phosphorylation of MAPKs in cultured macrophages. Biochem Biophys Res Commun. 1998;248:706-11.

18. Vitale G, Bernardi L, Napolitani G, Mock M, Montecucco C. Susceptibility of mitogen-activated protein kinase kinase family members to proteolysis by anthrax lethal factor. Biochem J. 2000; 352(Pt. 3):739-45.

19. Moayeri M, Leppla SH. Cellular and systemic effects of anthrax lethal toxin and edema toxin. Mol Aspect Med. 2009;30:439-55.

20. Koehler TM. Bacillus anthracis genetics and virulence gene regulation. Curr Top Microbiol Immunol. 2002;271:143-64.

21. Hudson M, Beyer W, Böhm R, Fasanella A, Garofolo G, Golinski R, Goossens PL, Hahn U, Hallis B, King A, Mock M, Montecucco C, Ozin A, Tonello F, Kaufmann S. Bacillus anthracis: balancing innocent research with dual-use potential. Int J Microbiol. 2008;298:345-64.

22. Tournier JN, Rossi Paccani S, Quesnel-Hellman A, Baldari CT. Anthrax toxins: A weapon to systematically dismantle the host immune defenses. Mol Aspect Med. 2009;30:456-66.

23. Leppla SH. Anthrax toxin edema factor: a bacterial adenylate cyclase that increases cyclic AMP concentrations in eukaryotic cells. Proc Natl Acad Sci USA. 1982;79:3162-6.

24. Leppla SH. Bacillus anthracis calmodulin-dependent adenylate cyclase: chemical and enzymatic properties and interactions with eukaryotic cells. Adv Cyclic Nucleotide Protein Phosphorylation Res. 1984;17:189-98.

25. Hambleton P, Turnbull PCB. Bacterial vaccines. New York, N.Y., Alan R. Liss, Inc.; 1990. p. 105-22. Anthrax vaccine development: a continuing story.

26. Gentile G, Ciammaruconi A, Anselmo A, Fortunato A, Palozzi AM, Ramisse AV. Whole genome comparison between Bacillus anthracis strains: The vaccine "Carbosap" and the 95014 isolate. Medical Biological Defense Conference, Munich, 22-25 October 2013. Abstract volume TP 05.
27. Turnbull PCB. Guidelines for the surveillance and control of anthrax in humans and animals, 3rd ed. World Health Organization WHO/EMC/ZDI/98.6; 1998. http://www.who.int/csr/ resources/publications/anthrax/WHO_EMC_ZDI_98_6/en/, Last accessed 19 March 2020.

28. Sobernheim G. Milzbrand. In: Kolle W, Kraus R, Uhlenhuth P, editors. Handbuch der pathogenen Mikroorganismen, 3rd expanded ed. Berlin, Vienna: Gustav Fischer and Urban \& Schwarzenberg; 1931, vol. 3, Part 2. p. 1041-174.

29. Tibbett M, Carter DO. Soil analysis in forensic taphonomy. Boca Raton, FL: CRC Press; 2008.

30. Minett FC. Sporulation and viability of $B$. anthracis in relation to environmental temperature and humidity. J Comp Pathol Ther. 1950;60:161-76.

31. Hugh-Jones M, Blackburn J. The ecology of Bacillus anthracis. Mol Aspects Med. 2009; https://doi.org/10.106/j.mqm.2009.08. 003, Last accessed 20 March 2020.

32. Driks A. The Bacillus anthracis spore. Mol Aspect Med. 2009;30: 368-73.

33. Goossens PL. Animal models of human anthrax: The quest for the Holy Grail. Mol Aspect Med. 2009;30:467-80.

34. Mock M, Fouet A. Anthrax. Annu Rev Micobiol. 2001;55:647-71.

35. Pervomajskij GS, Podoljan VJa (pod red). Parazitologija cheloveka. Slepni i sibirskaja jazva. Leningrad: Medicina; 1974. p. 502-3. [Russian].

36. Cherkasskiy BL, Burgasov SP. Sibirskaja jazva. In: Pokrovskij VI (pod red.). Rukovodstvo po zoonozam. Leningrad: Medicina; 1983. p. 207-17. [Russian].

37. Cross G. Dirty war: Rhodesia and chemical biological warfare 1975-1980. Helion \& Company; 2017.

38. Drankin DI, Malafeeva LS. Epidemiologiya i profilaktika infekcionnych zabolevanij pri professionalnych zarazhenyach. Moskva: Medicina; 1972. p. 44-84. [Russian].

39. Dragon DC, Bader DE, Mitchell J, Woollen N. Natural dissemination of Bacillus anthracis spores in northern Canada. Appl Environ Microbiol. 2005;71:1610-5.

40. Barandongo ZR, Mfune JKE, Turner WC. Dust-bathing behaviors of African herbivores and the potential risk of inhalational anthtrax. J Wildl Dis. 2018;54:34-44.

41. Wildführ G. Bacillus. In: Wildführ G, Wildführ W, editors. Medizinische Mikrobiologie, Immunologie und Epidemiologie, 2nd ed. Leipzig: VEB Georg Thieme; 1977. vol. II p. 735-46.

42. Beyer W, Turnbull PCB: review - Anthrax in animals. JMAM. 2009;30:481-89.

43. Kolonin GV. Nosogeography of anthrax in the USSR with regard to its regional epizootology. Zh Mikrobiol Epidemiol Immunobiol. 1969;46:91-7. [Russian].

44. Kassur B. 2.28. Bacillus-anthracis-Infektionen (Milzbrand). In: Brüschke G, editor. Handbuch der Inneren Erkrankungen. Vol. 5: Infektionskrankheiten, 1st ed. Jena; VEB Gustav Fischer Verlag; 1983. p. 717-9.

45. Rolle/Mayr. Medizinische Mikrobiologie, Infektions- und Seuchenlehre für Tierärzte, Biologen und Agrarwissenschaftler. Mayr A, editor. Bacillacae. 5th newly revised and expanded edition by Bachmann PA, Gedek B, Mahnel H, Mayr A, Schels H. Stuttgart: Ferdinand Enke Verlag; 1984. p. 839-46.

46. Brandis H. Über die Lebensdauer von Milzbrand- und Mesentericussporen. Zbl Bakt I Abt Orig. 1960;177:434-5. 
47. Strauch D. Veterinärhygienische Untersuchungen bei der Verwertung fester und flüssiger Siedlungsabfälle. In: Stralau J, Zoller BE, editor. Schriftenreihe aus dem Gebiete des öffentlichen Gesundheitswesens. Stuttgart: Georg Thieme; 1964. p. 18.

48. Manchee RJ, Broster MG, Stagg AJ, Hibbs SE, Patience B. Out of Gruinard Island. In Turnbull PCB, editors. Proceedings of the International Workshop on Anthrax. Salisbury Med Bull. 1990; 68(Suppl.):17-8.

49. BIG Prof. Ingenieurgesellschaft $\mathrm{mbH}$ : Milzbrandverdacht auf ehemaligen Standorten der Lederindustrie sowie ihrem Umfeld in Schleswig-Holstein. Abschlussbericht für das MLUR SchleswigHolstein, Projekt-Nr. P 01 219/09. Gehrden; 2010.

50. Chikerema S, Pfukenyi D, Hang'ombe B, L'Abee-Lund T, Matope G. Isolation of Bacillus anthracis from soil in selected high-risk areas of Zimbabwe. J Appl Microbiol. 2012;113:1389-95.

51. Agren J, Segerman B. Microevolution during a confined anthrax outbreak leading to clonal heterogeneity and penicillin resistance. Medical biodefense conference, 22-25 October 2013, Munich, oral presentation, No. 03, 26.

52. Lavander M, Jinnerot T, Agren P, Ehrs S, Kaden R, Ferarri S, Lindberg M, Nilsson C, Stephansson 0, Lundin Zumpe A. Detecting Bacillus anthracis in the food chain. Medical biodefense conference, 22-25 October 2013, Munich, Posters TP 08, 60.

53. de Vos V. The ecology of anthrax in the Kruger National Park, South Africa. In: Turnbull PCB, editor. Proceedings of the International Workshop on Anthrax. Salisbury Medical Bulletin. 1990; 68(Suppl.):19-23.

54. Wilson JB, Russel KE. Isolation of Bacillus anthracis from soil stored 60 years. J Bacteriol. 1964;87:237-8.

55. Aikimbayev AM, Lukhnova LY, Temiraliyeva GA, Gorelov YM. Current situation with anthrax in Kazakhstan. Quarantine and zoonotic infections in Kazakhstan. Alamty. Ed.3; 2001. p. 15-20.

56. Aikimbayev AM, Yesmagambetova AS, Zholshorinov AZ. Soil foci of anthrax in Kazakhstan. Potentially dangerous objects without the period of limitation. Environ Public Health Almaty. 2013;2: 55-69.

57. Turner WC, Kausrud KL, Beyer W. Lethal exposure: An integrated approach to pathogen transmission via environmental reservoirs. Sci Rep. 2016;6:27311.

58. Seifert HS, Böhnel H, Depping A, Giercke-Sygusch S, Heine A, Ranaivoson A, Roth F, Sukop U. Etiology and incidence of soilborne infection in Madagascar-evaluation of a 10-year research effort (1976-1986)]. Dtsch Tierarztl Wochenschr. 1988;95:22-7. [German].

59. Izbanova UA, Sutyagin VV, Lukhnova LY, Meka-Mechenko TV, Abdiyeva KA, Begimbaeva EG, Sadovskaya VP. The role of rodents in the persistence of anthrax soil foci. 16th Medical Biodefense Conference, Munich, 28-31 October 2018, Abstracts, oral presentation, p. 28

60. Seidel G. Die aeroben Sporenbildner unter besonderer Berücksichtigung des Milzbrandbazillus. In: Habs $\mathrm{H}$, Kathe J, editors. Beiträge zur Hygiene und Epidemiologie. No. 17. Leipzig: J. Ambrosius Barth Verlag; 1963. p. 27-103.

61. Christie AB. 3.15. Anthrax. In: Warrell DA, editor. (transl. Kleinheinz A). Infektionskrankheiten. Lehrbuch. Ed. Weinheim, Basel, Cambridge, New York: Medizin VCH; 1990. p. 311-6.

62. Lukhnova LY, Aikimbayev AM, Gorelov YM, Temiraliyeva GA. Anthrax prevention in Kazakhstan. Almaty. 2001:147.
63. Skrypnyk A, Skrypnyk V, Deriabin OM. Occurrence of anthrax foci in Ukraine. Med Biodefense Conference; 2011, Munich, 25-28 October 2011, Supplement to Medical Corps International Forum 2011;4/4:BP95, 34.

64. Aikimbayev AM. The biological safety system in Kazakhstan. In: Essbauer SS, Finke, E-J, Frey SO, Thoma B. ISBN 978-300052899-6; 2016. p. 75-88.

65. Buraceva NP, Mezencev VM, Ryazanova AG, Pluzhnikova OV, Eremenko EI, Maleckaya OV, Kulichenko AN. Ispol' zovanie GIS technologij pri razrabotke kadastra stacionarno neblagopoluchnych po sibirskoj yazve punktov v Krasnodarskom krae. Zh Mikrobiol, Epidemiol Immunbiol. 2014;2:59-64. [Russian].

66. Meselson M, Guillemin J, Hugh-Jones M, Langmuir A, Popova I, Shelokov A, Yampolskaya O. The Sverdlovsk anthrax outbreak of 1979. Science. 1994;5188:1202-8.

67. Inglesby TV, O’Toole T, Henderson DA, Bartlett JG, Ascher SA, Eitzen E. Anthrax as a biological weapon: updated recommendations for management. In: Henderson DA, Inglesby TV, O'Toole T, editors. Bioterrorism. Guidelines for medical and public health management. American Medical Association; 2002. p. 63-97.

68. Guillemin J. Biological weapons. From the invention of statesponsored programs to contemporary bioterrorism. New York: Columbia University Press; 2005.

69. Seidemann RM, Wheeler KH. Elephant tusks, a source of human anthrax. Rev Bull Hyg (London). 1948:23:248.

70. Eck H. Über zwei seltene Beobachtungen von tödlichen Gasbrandund Milzbrandinfektionen. Z Hyg Infektionskrankheiten. 1949; 129:97-102.

71. James DG. Epidemiology of anthrax. J Antimicrob Chemother. 1976;2:319-20.

72. Brooks T. Unusual diseases in UK. Oral presentation at the 12th Medical Biological Defense Conference, Munich, 21 October 2009.

73. ProMED-mail. Anthrax, human - USA (08): (NEW HAMPSHIRE). Archive Number 20100419.1269. Published Date: 201004-19. Date: Sun 18 Apr 2010. Source: Nashua Telegraph [edited] http://www.nashuatelegraph.com/news/709412-196/anthraxvictim-fine-mystery-remains.html, Last accessed 18 March 2020.

74. Turnbull PCB, Kramer JM. Ch. 33 Bacillus. In: Balows A, Hausler WJ, Jr, Herrmann KL, Isenberg HD, Shadomy HJ, editors. Section IV. Bacteria. Manual of clinical microbiology. 5th ed. Washington DC: American Society of Microbiology; 1991. p. 297-8.

75. Lew D. Bacillus anthracis (Anthrax). In: Mandell GL, Bennett JE, Dolin R, editors. Mandell, Douglas and Bennett's principle and practice of infectious diseases, 4th ed. New York: Churchill Livingstone Inc.; 1995, Vol. 2. p. 1885-9.

76. Mohr W. Milzbrand. In: Gsell O, Mohr O. Infektionskrankheiten, vol. II. Berlin, Heidelberg, New York: Springer; 1968. p. 752-74.

77. Bezdenezhnych IS- Epidemiologija, Izd. 2. Moskva: Medicina; 1971. p. 284-8.

78. Kulichenko AN, Eremenko EI, Buravceva NP, Rjazanova AG. Diagnostika sibirskoj jazvy v Rossijskoj Federacii. Zh Mikrobiol Epidemiol Immunobiol (Moscow). 2010;5;62-6. [Russian].

79. Chandra Sekhar P, Jaya Bhaskar C, Sridhar MS, Jaya Singh RS, Sreehari Rao Y. Outbreak of human anthrax in Ramabhadrpuram village in Chitoor district of Andhra Pradesh, Indian J Med Res. 1990;91:448-52.

80. ProMED-mail. Publishing Date: 2018-02-12 15:38:12. Subject: PRO/AH/EDR> Anthrax - Turkey: (Trabzon) bovine, human. 
Archive Number: 20180212.5623312. Date: Sun 11 Feb 2018 13: 49:27 TRT .Source: Hürriyet Daily News [edited] http://www. hurriyetdailynews.com/one-killed-73-people-taken-to-hospitalover-suspicions-of-anthrax-in-turkeys-north-127121, Last accessed 21 June 2018.

81. ProMED-mail. Anthrax, human - USA (09): (NH). Archive Number 20100724.2476. Published Date: 2010-07-24. Source: CDC MMWR Weekly/ 59(28);872-7 [edited] http://www.cdc.gov/ mmwr/preview/mmwrhtml/mm5928a3.htm. Date: 23 Jul 2010. Last accessed 18 March 2020.

82. Tsilosani M, Malakmadze N, Simsive T, Gvetadze K, Tsaava Z, Zviadadze D, Shavgulidze M, Zakhashvili K. Lethal outcome of the first case of oropharyngeal anthrax reported in Georgia, 2017. 16th Medical Biodefense Conference, Munich. 28-31 October 2018, Abstracts, oral presentation, p. 29.

83. Greenfield WS. Supplementary Report on the Woolsorter's disease in the Bradford District. Eleventh Annual Report of the Medical Office of the Local Government Board. London; 1881-1882. p. 207-38.

84. Eurich FW. Anthrax in the woolen industry with special emphasis to Bradford. Proc Royal Soc Med. 1912-1913;6:219-35.

85. Fraenkel E. Über Inhalationsmilzbrand. Virchows Arch Path Anat. 1925;254:363-78.

86. Eppinger H. Die Hadernkrankheit, eine typische InhalationsMilzbrandinfection beim Menschen unter besonderer Berücksichtigung ihrer pathologischen Anatomie und Pathogenesis auf Grund eigener Beobachtungen dargestellt. Jena: G Fischer; 1894. p. 139-41.

87. Albrink WS, Brooks SM, Biron RE, Kopel M. Human Inhalation anthrax. Am J Pathol. 1960;36:457-67.

88. Albrink WS, Brooks SM, Biron RE, Kopel M. Human inhalation anthrax: A report of three fatal cases. Am J Pathol. 1960;35: 1055-65.

89. Abramova FA, Grinberg LM, Yampolskaya OA, Walker DH. Pathology of inhalational anthrax in 42 cases from the Sverdlovsk outbreak of 1979. Proc Natl Acad Sci USA. 1993;90:2291-94.

90. Friedlander AM. Chapter 22 Anthrax. In: Sidell FR, Takafuji ET, Franz DR, editors. Medical aspects of chemical and biological warfare. Textbooks of military medicine. Part I. In: Zajtchuk R, editor. Warfare, Weaponry, and Casualty. Washington, DC: Office of The Surgeon General at TMM Publications Borden Institute Walter Reed Army Medical Center; 1997. p. 467-78.

91. Bischoff H, Schwiening H, Hoffmann W, Hetsch H, Kutscher KH, Martinek O. 22. Kapitel. Milzbrand. In: Bischoff H, Hoffmann W, Schwiening H, editors. Infektionskrankheiten und nicht infektiöse Armeekrankheiten. Lehrbuch der Militärhygiene. Berlin: Verlag von August Hirschwald; 1912, vol. IV. p. 365-9.

92. Brachman PS, Plotkin SA, Bumford FH, Atchison MM. An epidemic of inhalation anthrax: the first in the twentieth century. II. Epidemiology. Am J Hyg. 1960;72:6-23.

93. Brachman PS, Pagano JS, Albrink MS. Two cases of fatal inhalation anthrax, one associated with sarcoidosis. New Engl J Med. 1961;265:203-8.

94. Mayr A. Bacillacae. In: Bachmann PA, Gedek B, Mahnel H, Mayr A, Schels H, editors. Rolle/Mayr Medizinische Mikrobiologie, Infektions- und Seuchenlehre für Tierärzte, Biologen und Agrarwissenschaftler. 5. neu bearbeitete und erweiterte Aufl. Stuttgart: Ferdinand Enke Verlag; 1984. p. 839-46.
95. Bauerfeind R, Kimmig P, Schiefer HG, Schwarz T, Slenzka W, Zahner $\mathrm{H}$, editors. Zoonosen, 4th completely revised and expanded edition. Köln: Deutscher Ärzte-Verlag; 2013. p. 236-41.

96. Brachman PS, Plotkin SA. Field evaluation of human anthrax vaccine. Am J Public Health. 1962;52:632-45.

97. Knight AH, Wynne-Williams CEJ, Willis AT. Cutaneous Anthrax - the Non-industrial Hazard. Brit Med J. 1969;1:416-8.

98. Severn M. A fatal case of pulmonary anthrax. Br Med J. 1976;1: 748.

99. Dutz W, Kohout E. Anthrax. Pathol Annu. 1971;6:209-48.

100. Sejvar JJ, Tenover FC, Stephens DS. Management of anthrax menigitis. Lancet Infect Dis. 2005;5:287-95.

101. Grunow R, Verbeek L, Jacob D, Holzmann T, Birkenfeld G, Wiens D. Injektionsmilzbrand - neu aufgetretene Fälle bei Heroinabhängigen. Dtsch Ärztebl. 2012;109:843-8.

102. Ringertz SH, Hoiby EA, Jensenius M, Maehlen J, Caugant DA, Myklebust A, Fossum K. Injectional anthrax in a heroin skinpopper. Lancet. 2000;356:1574-5.

103. Grass G, Klee SR, Beyer W, Wagner GM, Pearson T, Sandven P, Kjerulf A, Hanzaruk M, Keim P, Grunow R. Genotyping of Bacillus anthracis strains from extended outbreaks of injectional anthrax in drug consumers. Medical Biodefense Conference, 22-25 October 2013, Munich, oral presentation G04, 15.

104. Parcell BJ, Wilmshurst AD, France AJ, Motta I, Brooks T, Olver WJ. Injection anthrax causing compartment syndrome and necrotizing fasciitis. J clin Pathol. 2011;64:95-6.

105. Robert Koch Institut. Milzbrand (Anthrax) - Kurzinformation anlässlich Milzbrand bei Heroingebrauchern in Deutschland. Münchn Ärztl Anzeig. 2012;14:16-7.

106. Holzmann T, Frangoulidis D, Simon M. Fatal anthrax infection in a heroin user from Southern Germany, June 2012. Euro Surveill. 2012;17:26.

107. Berger T, Kassirer M, Aran AA. Injectional anthrax - new presentation of an old disease. Euro Surveill. 2014;19:32.

108. Bartels C, Pharris A, Jansen A, Magiorakos A, Wiessing L. Evidence based guidance on prevention of anthrax in people who inject drugs. Medical biodefense conference, 22-25 October 2013, Munich, Posters TP 02, 58-59.

109. Ahrens B, Grass G, Dobrzykowski L, Wagner M, Krüger C, Schleenbecker U, Wölfel R. Screening of heroin for Bacillus anthracis-contamination. 15th Medical Biodefense Conference, 26-28 April 2016, Munich, DP16, 38.

110. Anonymous. An outbreak of anthrax among drug users in Scotland, December 2009 to December 2010. A report on behalf of the National Anthrax Control Team. http://www.documents.hps.scot.nhs.uk/giz/ anthrax-outbreak-report-2011-12.pdf. http://www.promedmail.org/? $\mathrm{p}=2400: 1000$, Last accessed 5 January 2012.

111. Pfisterer RM: Eine Milzbrandepidemie in der Schweiz. Schweiz Med Wschr. 1991;121:813-25.

112. Schmid G, Kaufmann A. Anthrax in Europe: its epidemiology, clinical characteristics, and role in bioterrorism. Clin Microbiol Infect. 2002;8:479-88.

113. Breathnach AS, Turnbull PC, Eykyn SJ, Twort CH. A labourer with a spot on his chest. Lancet. 1996;347:96.

114. Weber A. Aufgaben der Untersuchungsämter bei der Zoonosebekämpfung. Hohenheimer Seminar der Deutschen Veterinärmedizinischen Gesellschaft, Stuttgart-Hohenheim. Vortragsband; 1996. p. 18-38. 
115. Dyson H. Who needs anthrax vaccine? Oral presentation. 15th Medical Biodefense Conference, 26-28 April 2016, Munich. MO1, 23.

116. Sykes A, Brooks T, Dusmet M, Nicholson AG, Hansell DM, Wilson R. Inhalational anthrax in a vaccinated soldier. European Respiratory Journal. 2013;42:285-7.

117. Brooks T. Death is only the beginning: the complex manifestation of anthrax. Anthrax Counter Measures 2013 International Conference Proceedings, Royal United Services Institute, London, 4 February 2013. Mil Med Sci Lett (Voj Zdrav Listy). 2013;82:73.

118. Büyük F, Celebi Ö, Linley E, Cooper C, Doganay M, Sahin M, Baillie LW. The impact of environmental contamination with Bacillus anthracis spores on human health. 15th Medical Biodefense Conference, 26-28 April 2016, Munich, L04, 22.

119. Cordeiro R, Pelerito J, Orterga F, Rosario J, Escoval R, Febra P, Nuncio MS. Human Bacillus anthracis infection in Southern Portugal: An uncommon finding? Medical biodefense conference, 22-25 October 2013, Munich, oral presentation, CO 02, 9.

120. ProMED-mail. Published Date: 2018-08-30 15:19:44. Subject: PRO/ AH/EDR > Anthrax (02): virulence, confirmation. Archive Number: 20180830.5997664. Source: Phys.Org [edited] https://phys.org/ news/2018-08-genomic-anthrax-strains-virulence-clues.html. Last accessed 31 August 2018.

121. Dott W, Kämpfer P. Mikrobiologisch/hygienische Beurteilung des Gefährdungspotentials von Bakterien aus Boden- und Wasserproben im Zusammenhang mit biotechnologischen Verfahren zur Bodensanierung. Zbl Hyg. 1997;200:163-71.

122. Simonova EG, Galkin VV, Loktionova MN, Ladny VI. Anthrax cattle burial grounds in Russia and their biosafety. Zh Mikrobiol Epidemiol Immunobiol (Moscow). 2010;4:23-6. [Russian].

123. Anonymous. Leitfaden zur Erkundung ehemaliger Gerbereistandorte, UBA, FG III 3.6, PT AWAS; 1998.

124. BGI 583. Biologische Arbeitsstoffe bei der Bodensanierung (bisherige ZH 1/186), Merkblatt Tiefbau-Berufsgenossenschaft; 1999.

125. Tikhomirov SN. 1939-1945: Environmental aspects of the war in Europe. Rev Cent East Eur Law. 2006;31:111-25.

126. Harris S. Factories of death: Japanese Biological Warfare: 19321945 and the American Cover-up. London, New York: Routlegde; 1995.

127. Carus WS. Bioterrorism and Biocrimes: The illicit use of biological agents in the 20th century. Washington, DC: National Defense University; August 1998.

128. Carter GB, Pearson GS. British warfare and biological defence, 1925-45. In: Geissler E, van Courtland Moon JE, editors. Biological and Toxin Weapons: Research, Development, and Use from the Middle Ages to 1945. SIPRI Chemical and Biological Warfare Studies 18. New York: Oxford University Press; 1999. p. $168-89$.

129. Geissler E, van Courtland Moon JE, editors. Biological and Toxin Weapons: Research, Development, and Use from the Middle Ages to 1945. SIPRI Chemical and Biological Warfare Studies 18. New York: Oxford University Press; 1999. p. 35-62.

130. Wheelis M. Biological sabotage in World War I. In: Geissler E, van Courtland Moon JE, editors. Biological and toxin weapons: research, development, and use from the middle ages to 1945 . SIPRI Chemical and Biological Warfare Studies 18. New York: Oxford University Press; 1999. p. 35-62.
131. Alibek K, Handelman S. Biohazard. The chilling true story of the largest covert biological weapons program in the world. New York: Random House; 1999.

132. Leitenberg M. Biological weapons in the twentieth century: a review and analysis. Crit Rev Microbiol. 2001;27:267-320.

133. Roffey R, Tegnell A, Elgh F. Biological warfare in a historical perspective. Clin Microbiol Inf. 2002;8:450-4.

134. Carus WS. A short history of biological warfare: from pre-history to the 21st century. Center for the Study of Weapons of Mass Destruction, Occasional paper 12. Washington, DC: National Defense University Press; August 2017.

135. Manchee RJ, Broster MG, Melling J, Henstridge RM, Stagg AJ. Bacillus anthracis on Gruinard Island. Nature. 1981;291:254-5.

136. Hammond P, Carter G. From biological warfare to healthcare. Porton down 1940-2000. Houndmills, New York: Palgrave; 2002. p. 13-5.

137. Hussel L. Milzbrand. In: Spezielle Tierseuchenbekämpfung. Jena: VEB Gustav Fischer; 1960. p. 300-11.

138. Anonymous. Upravlenie Medicinskoj cluzhby Vengerskoj Narodnoj Armii. Reg. No 070/121/1983: Anthrax (sibirskay jazva, pustula maligna. In: Anonymous. Prirodnye ochagi antroponoza v Evrope. Tema IV.10 "Ochagi antroponoza" "lana nauchno-issledovatel' skich rabot 1970-1988. Pers. Archiv Finke EJ. [Russian].

139. ProMED-mail. Published Date: 2012-03-25 21:09:26. Subject: PRO/ AH> Anthrax, livestock - Russia: (Central Region) Bad season predicted. Archive Number: 20120325.1080456. Date: March 20, 2012. Source: TheMoscowNews.com, http://themoscownews.com/ russia/20120320/189548960.html, Last accessed 19 March 2020.

140. Abdrakhmanov SK, Mukhanbetkaliyev YY, Korennoy FI, Sultanov AA, Kadyrov AS, Kushubaev DB, Bakishev TG. Maximum entropy modelling risk of anthrax in the Republic of Kazakhstan. Prevent Vet Med. 2017;144:149-57.

141. ProMED-mail. Anthrax - Germany: Sachsen-Anhalt, (ST) bovine. http://www.promedmail.org/ Archive Number: 20140417. 2412006. Date: 17 Apr 2014. Source: RP Online/DPA [in German, trans. Sabine Zentis, edited] http://www.rp-online.de/ panorama/deutschland/milzbrand-in-rinderherde-in-sachsenanhalt-ausgebrochen-aid-1.4183604, Last accessed 19 April 2019.

142. Elvander M, Persson B, Sternberg Lewerin S. Historical cases of anthrax in Sweden 1916-1961. Transboundary Emerg Dis. 2017; 64:292-8.

143. Braus A. Milzbrandbekämpfung in South Omo. Dtsch Tierärztebl. 2018;66:1084-7.

144. Kaufmann AF. Observations on the occurrence of anthrax related to soil type and rainfall. In: Turnbull PCB, editor. Proceedings of the international workshop on anthrax. Salisbury Med Bull. 1990; vol. 68 (Suppl). p. 16-7.

145. Sahin M, Cooper C, Büyük F, Celebi Ö, Celik E, Gülmez Saglam A, Otlu S, Baillie LW. The changing faces of Bacillus anthracis in soil. 15th medical biodefense conference, 26-28 April 2016, Munich, DP21; 39.

146. Schuch R, Fischetti VA. The secret life of the anthrax agent $B a-$ cillus anthracis: bacteriophage-mediated ecological adaptations. PLoS One. 2009;4:e6532.

147. Van Ness GB. Ecology of anthrax. Anthrax undergoes a propagation phase in soil before it infects livestock. Science. 1971;172: 1303-7. 
148. Dey R, Hoffman PS, Glomski IJ. Germination and amplification of anthrax spores by soil-dwelling amoebas. Appl Environ Microbiol. 2012;78:8075-81.

149. Benner AK. Untersuchungen zum Verhalten GFP- markierter phageninfizierter und nicht phageninfizierter Bacillus anthracis Stämme in verschiedenen Amöbenspezies. Diploma Thesis Institut für Umwelt- und Tierhygiene sowie Tiermedizin Universität Hohenheim Stuttgart; 2013. [German].

150. Braun P, Grass G, Aceti A, Serrecchia L, Affuso A, Marino L, Grimaldi S, Pagano S, Hanczaruk M, Georgie E, Northoff B, Schoeler A, Scholter M, Antwerpen MH, Fasanella A. Microevolution of anthrax from a young ancestor (m.a.y.a.) suggests a soilborne life cycle of Bacillus anthracis. Workshop on Anthrax countermeasures: Vaccine and environmental decontamination. PloS One;2015;10:e0135346.

151. Saile E, Koehler TM. Bacillus anthracis multiplication, persistence, and genetic exchange in the rhizosphere of grass plants. Appl Environ Microbiol. 2006;72:3168-74.

152. Brahmbhatt TN. Bacillus anthracis exosporium protein BcIA affects spore germination, interaction with extracellular matrix proteins, and hydrophobicity. Infect Immun. 2007:75: 5233-9.

153. White CP, Popovici J, Lytle DA, Rice EW. Endospore surface properties of commonly used Bacillus anthracis surrogates vary in aqueous solution. Antonie Van Leeuwenhoek. 2014;106:243-51.

154. ProMED-mail. Published Date: 2014-06-06 13:52:02. Subject: PRO/AH> Anthrax: new ecological research. Archive Number: 20140606.2523686. In this posting: Date: Sun 11 May 2014 [ahead of publication] Source: Antonie Van Leeuwenhoek journal [edited]. http://www.ncbi.nlm.nih.gov/pubmed/24817579, Last accessed 19 March 2020.

155. Grass G, Braun P, Aceti A, Serrechia L, Marino L, Hanczaruk M, Georgi E, Antwerpen M, Fasanella A. Preliminary results of a genomic approach for probing a possible soil-borne life cycle of Bacillus anthracis. ASM biodefense and emerging diseases research meeting. 09-11.02.2015, Washington DC, USA; 2015.

156. Lindeque PM, Turnbull PC. Ecology and epidemiology of anthrax in the Etosha National Park, Namibia. Onderstepoort J Vet Res. 1994;61:71-83.

157. Green A. UK Statement: Subject: FW: medical/ epidemiological question/ the British experience SG JMC MEDD-DCA CDC (Green, Andy Gp Capt) SGJMCMEDD-DCACDC@mod.uk EMail Date: Fri, 24 Jan 2014 13:07:06 -0000 HealthPol-AdviceAD@mod.uk, SGACDSStratPol-DPHUAHPubHlth@mod.uk, andrew.green12@doctors.org.uk.

158. Popov VG, Pchelintsev SY, Karkischenko NN, Ozerov MY, Beyer W, Grishin DA. Neutralization of B. anthracis spores by new disinfectant. Medical biodefense conference 2009, 20-22 October 2009, Munich, Medical Corps International Forum 4/2009, Supplement. Poster CP98, 27.

159. Schaible Milzbrand bei Pferden. Mitteilungen des Vereins badischer Tierärzte; 1912.

160. Gaiger SH. Anthrax spores cause infection from a grave after twenty-four years. Vet J. 1926;82:497-8.

161. Descotes JP, Joubert L. Reconversions epidemiologigues actuelles de la fievre charbonneuse. Rev Med Vet. 1978;129:1209-21.

162. ProMED-mail. Anthrax, bovine - France: (Doubs). Archive Number 20080818.2572. Published Date 2008-08-18. Date: 14 Aug
2008. Source: Landwirtschaft.ch [edited]. http://www. landwirtschaft.ch/de/aktuell/agronews/detail/article/2008/08/14/ milzbrand-faelle-im-osten-frankreichs/, Last accessed 19 March 2020.

163. Cinquetti G, Banal F, Dupuy AL, Girault PY, Couderc A, Guyot P. Three related cases of cutaneous anthrax in France: clinical and laboratory aspects. Medicine (Baltimore). 2009;88:371-5.

164. OIE Surveillance, www.oie.int Vol. 30. No. 32 (3 July 2017), Last acessed 24 January 2018.

165. Joyner TA, Lukhnova L, Pazilov Y. Modeling the potential distribution of Bacillus anthracis under multiple climate change scenarios for Kazakhstan. PLoS One. 2010;5:e9596.

166. ProMED-mail. Publishing Date: 2017-10-25 13:21:07. Subject: $\mathrm{PRO} / \mathrm{AH} / \mathrm{EDR}>$ Anthrax fears - UK: (England) cattle grave concerns. Archive Number: 20171025.5403456. Date: Tue 24 Oct 2017. Source: The Shuttle [edited] https://goo.gl/B2y2bT, Last accessed 19 March 2020.

167. Antwerpen MH, Georgi E, Zimmermann P, Hörmansdörfer S, Meyer H, Grass G. Genome sequence of a novel Lysinibacillus-like Bacillus strain (BF-4) isolated during an anthrax outbreak 2009 in Germany. Medical biodefense conference, 22-25 October 2013, Munich, Poster NP 01, 48.

168. Böhm R. Die Bedeutung von Desinfektionsmaßnahmen in der Veterinärmedizin. Hohenheimer Seminar Deutsche Veterinärmedizinische Gesellschaft, Zoonose-Tagung Universität Stuttgart-Hohenheim. Vortragsband; 196. p. 136-46.

169. ECDC Surveillance Report. Annual epidemiological report for 2016 Anthrax. Stockholm: ECDC. Last accessed, 25 August 2019.

170. Lukhnova LY, Aikimbayev AM, Pazylov EK. Epidemic process of anthrax in Kazakhstan. Bull Agric Sci Kazakhstan Bastau. 2004; $7: 44$.

171. Aikimbayev AM, Lukhnova L, Temiraieyeva G, Meka-Mechenko T, Pazylov Y, Zakaryan S. Historical distribution and molecular diversity of Bacillus anthracis, Kazakhstan. Emerg Inf Dis. 2010; 16:789-96.

172. Antyuganov SN, Ryazanova AG, Eremenko EI. Anthrax in the Russian Federation and abroad. Epidemiol Infect Dis. 2012;5:4-8. [Russian].

173. Cherkasskiy BL. Epidemiology and prevention of anthrax. Moskva: Medicina; 2002. [Russian].

174. Porgelskaja LV. Sibirskaja jazva. In: Ilinskij JuA, Luchsheva VM, editors. Tropicheskie bolezni. T74 Medicina; 1984. p. 69-75. [Russian].

175. Kazancev, AP. Sibirskaja jazva (Anthrax). In: Kazancev AP,Matkovskij BS. Spravochnik po infekcionnym boleznjam. 3-e Izd., pererab, i dop. Moskva: Medicina; 1985. p. 227-30. [Russian].

176. Lukhnova LY, Bakhyt A, Nekrassova L, Meka-Mechenko T, Kazakov IU, Sushchnikh V. Assessment of risk of infection of people and animals at contact with natural (the soil foci) or artificial (laboratory) of anthrax reservoirs. 15th medical biodefense conference, 26-28 April 2016, Munich, Poster IP9, Abstract 52.

177. Sklyarov VYa. On the spread of anthrax in the Stavropol Region. Zh Mikrobiol Epidemiol Immunobiol. 1964;41:138-41. [Russian].

178. Vasil 'iev. PG, Sadykov NS, Machmutkin VA, Vasil`ev AP. Epizootologo-epidemiologicheskoe rajonirovanie povolzhskogo, volgo-vjatskogo i juzhno-ural skogo regionov po stepeni riska voznikovenija sluchaev sibriskoj jazvy. In: Materialy nauchno- 
prakticheskoj konferencii, posvjashchennoj 100-letiju obrazovanija portivochumnoj sluzhby Rossii. V dvuch tomach. Tom 1, Rossijskij nauchno-issledovatel' skij protivchumnyj institut "Mikrob", Saratov; 1997. p. 18-9.

179. Kireev JuG, Prometnoj VI: Sovershenstvovanie epidemiologicheskogo nadzora za sibirskoj jazve. In: Materialy nauchno-prakticheskoj konferencii, posvjashchennoj 100-letiju obrazovanija portivochumnoj sluzhby Rossii. V dvuch tomach. Tom 1, Rossijskij nauchno-issledovatel 'skij protivchumnyj institut "Mikrob", Saratov; 1997. p. 62. [Russian].

180. Imnadze P; Bakanidze L, Katsitadze G, Mlania L, Kekelidze M. Anthrax in Georgia: 2000-2005. 2006 NIAID Research Conference. 2005; 24-30 June. Abstract volume, 3.

181. Kracalik I, Abdullayev R, Asadov K, Ismayilova R, Baghirova M, Ustun N. Changing patterns of human anthrax in Azerbaijan during the post-Soviet and preemptive livestock vaccination eras. PLoS Neglected Trop Dis. 2014;8:1-11.

182. Kracalik I, Malania L, Tsertsvadze N, Manvelyn J, Bakanidze L, Imnadze P. Human cutaneous anthrax, Georgia 2010-2012. Emerg Inf Dis. 2014;20:261-4.

183. Taviev VM, Malysheva MN. Some epidemiological pecularities of anthrax outbreaks in one of the sovkhozes in the Saratov Region. Zh Mikrobiol Epidemiol Immunobiol. 1963;40:129-32. [Russian].

184. Onishchenko GG, Kulichenko AN, Ryazanova AG, Demina YuV, Kriga AS, Eremenko EI. Analiz vspyshki sibirskoj jazvy v Omskoj oblasti v 2010 g. Zh Mikrobiol Epidemiol Immunobiol (Moscow). 2010;5;33-6. [Russian].

185. Cherkasskiy BL. ProMED-mail: Anthrax, cattle gravesites - Russia (Urals). Published Date: 2004-02-19 23:50:00. Archive Number: 20040219.0539 [1]. Date: 18 Feb 2004. Source: RIA Vesti, 29 Jan 2004 [edited] http://en.rian.ru/rian/index.cfm, Last accessed 7 February 2019.

186. Evremenko VI, Grizhebovskij M, Bogdanov IK, Kalashnikov IA, Suvorova AE, Petrjuk VA. Epidemiologicheskaja situacija po opasnym infekcijam na juge Rossii. Materialy nauchno-prakticheskoj konferencii, posvjashchennoj 100-letiju obrazovanija portivochumnoj sluzhby Rossii. V dvuch tomach. Tom 1, Rossijskij nauchno-issledovatel'skij protivchumnyj institut "Mikrob", Saratov; 1997. p. 46.

187. Juzvik LN, Agapov VA. Osobennosti epidemiologicheskich projavlenij pri sibirskoj jazve v Zabajkal`e, In: Materialy nauchnoprakticheskoj konferencii, posvjashchennoj 100-letiju obrazovanija portivochumnoj sluzhby Rossii. V dvuch tomach. Tom 1, Rossijskij nauchno-issledovatel' skij protivchumnyj institut "Mikrob", Saratov; 1997. p. 165. [Russian].

188. Bakanidze L. Anthrax in Georgia: 2000-2005. Geneva; 2009.

189. Hugh-Jones M. Comment in: ProMED-mail: ANTHRAX - USA (03): (MINNESOTA) Archive Number: 20110811.2437. Published Date: 11-AUG-2011. Date: Wed 10 Aug 2011. Source: CIDRAP (Center for Infectious Disease Research \& Policy) News edited. http://www.cidrap.umn.edu/cidrap/content/bt/anthrax/ news/aug1011anthrax.html, Last accessed 19 March 2020.

190. Omasheva G, Aikimbayev A, Durumbetov E. Microbiological characteristics of Bacillus anthracis in Kazakhstan and perspectives of genotyping. 16th Medical Biodefense Conference, Munich. 28-31 October 2018, Abstracts, oral presentation, JP 01, 79.
191. Kutmanova A, Doganay M, Zholdoshev S. Human anthrax in Kyrgyz Republic; Epidemiology and clinical features. 16th Medical Biodefense Conference, Munich. 28-31 October 2018, Abstracts, oral presentation, PP 26.

192. Buurma K, Tsogbadrakh, Ganbileg G, Darmaa, Davaa G. Epidemiological features of human anthrax cases in Mongolia. Poster KP7, Abstracts. 15th Medical Biodefense Conference, 26-28 April 2016, Munich, p. 62-3.

193. Li Y, Hugh-Jones M, Wang L, Mu D, Ren X, Zeng L, Chen Q. Epidemiology of human anthrax in China, 1955-2014. Emerg Inf Dis. 2017;23:14-21.

194. Zasada AA, Ogrodnik A, Gierczynski R. Occurrence of Bacillus anthracis spores in selected areas of Poland affected by floods in 2011. Med Biodefense Conference, 2011, Munich, 25-28 October 2011, Supplement to Medical Corps International Forum 4./4Poster BP91, 33.

195. ProMED-mail. Anthrax, historic cemetery - United Kingdom: (London) http://www.promedmail.org Archive number: 20100322.0907. Date: 19 Mar 2010. Source: , Last accessed 25 October 2017.

196. Popescu R, Pistol A, Miltaru L, Caplan D, Cuculu R, Popovici F. Two cases of infection with Bacillus anthracis, Romania, October 2011. Euro Surveill. 2011;16:45.

197. SchlottauKLederindustrie. Schriftenreihe des Amtes f. Natur u. Umwelt d. Stadt MünsterBd. 21992.

198. Wattiau P, Govaerts M, Frangoulidis D, Fretin D, Kissling E, Van Hessche M, China B, Poncin M, Pirenne Y, Hanquet G. Immunological response of unvaccinated workers exposed to $B$. anthracis spores, Belgium. Emerg Infect Dis. 2009;15:1637-40.

199. Wattiau P, Klee SR, Fretin D, Van Hessche M, Ménart M, Franz T, Chasseur $\mathrm{C}$, Butaye $\mathrm{P}$, Imberechts $\mathrm{H}$. Occurrence and genetic diversity of Bacillus anthracis strains isolated in an active woolcleaning factory. Appl Environ Microbiol. 2008;74:4005-11.

200. Afanasev MV, Kravets EV, Dugorzhapova ZF, Takayshvilli VE, Balakhonov SV. The first molecular snapshot of Bacillus anthracis strains circulating in Siberia and at the Far East. Medical biodefense conference. 22-25 October 2013, Munich, Poster TP 01, 58.

201. Grunow R. Hinweise zu Sicherheitsaspekten bei der pathologischen Untersuchung von an Anthrax verstorbenen Menschen und Tieren sowie deren Bestattung bzw. Entsorgung (bearb. von Andernach I und Böttcher JP). ZBS, Robert Koch Institut Berlin, 14 February 2014.

202. ProMED-mail. Anthrax, cattle gravesites - Russia (Urals) Published Date: 2004-02-19 23:50:00. Archive Number: 20040219.0539 [1] Date: 18 Feb 2004. Source: RIA Vesti, 29 Jan 2004 [edited] http://en.rian.ru/rian/index.cfm, Last accessed 7 February 2019.

203. Pyper JF, Willoughby L. An anthrax outbreak affecting man and buffalo in the Northwest territories. Med Sev J Can. 1964;20: 531-40.

204. Griffith J, Blaney D, Shadomy S, Lehman M, Pesik N, Tostenson S, Delaney L, Tiller R, DeVries A, Gomez T, Sullivan M, Blackmore C, Stanek D, Lynfield R. Investigation of Inhalation Anthrax Case, United States. Emerg Inf Dis. 2014:20:280-3.

205. ProMED-mail. ANTHRAX - USA (09): (MINNESOTA). Archive Number: 20110831.2670. Published Date: 2011-08-31. Date: Tue 30 Aug 2011. Source: CIDRAP (Center for Infectious Disease Research \& Policy) News [edited] http://www.cidrap.umn.edu/cidrap/ 
content/bt/anthrax/news/aug3011anthrax.html, Last accessed 19 March 2020.

206. Ogarkov VI, Gapochko KG. Aerogennaya infekcija. Moskva: Medicina; 1975. [Russian].

207. Defence Intelligence Agency. Soviet biological warfare threat. Washington, DC: US Dept. of Defense. Publ.; 1986. DST-161OF057-86.

208. Friedlander AM, Welkos SL, Pitt ML, Ezzell JW, Worsham PL, Rose KJ, Ivins BE, Lowe JR, Howe GB, Mikesell P. Postexposure prophylaxis against experimental anthrax. J Infect Dis. 1993;167: 1239-43.

209. Cieslak TJ, Eitzen EM, Jr. Clinical and epidemiological principles of anthrax. Emerg Inf Dis. 1999;5:552-7.

210. Louveau C, Darfeuille M, Raiteux J, Mery P, Plecis A, Morel Y. Aerosol virulence variability of $B$. anthracis strains. Med Biodefense Conference; 2011, Munich, 25-28 October 2011, Supplement to Medical Corps International Forum 4./4-2011, Abstracts. E025. 15.

211. Beyer W, Bartling K, Neubauer. Bacillus anthracis (Milzbrand). In: MIQ 26; 2008, p. 38-54.

212. Chung E, Yiacoumi S, Lee I, Tsouris C. The role of electrostatic force in spore adhesion. Environ Sci Technol. 2020;44:6209-14.

213. Druett HA, Henderson DW, Packman L, Peacock S. Studies on respiratory disinfection. I. The influence of particle size on respiratory infection with anthrax spores. J Hyg. 1953;51:359-71.

214. Matsumoto G: Anthrax powder: state of the art? Sci New Ser. 2003;302:1492-95+1497.

215. Plettenberg A, Stoehr A. Milzbrand: Aktuelles zum Erreger, Krankheitsbild möglichem Einsatz als biologische Waffe. Hamburger Ärztebl. 2001;11:546-7.

216. Bales ME, Dannenberg AL, Brachman PS, Kaufmann AF, Klatsky PC, Ashford DA. Epidemiological response to anthrax outbreaks: Field investigations, 1950-2001. Emerg Infect Dis. 2002;8: 1163-74.

217. Inglesby TV, Henderson DA, Bartlett JG, Ascher MS, Eitzen E, Friedlander AM, Hauer J, McDade J, Osterholm MT, O'Toole T, Parker G, Perl TM, Russell PK, Tonat K. Anthrax as a biological weapon: medical and public health management. JAMA. 1999; 281:1735-45.

218. Gold H. Anthrax: a report of 117 cases. Arch Intern Med. 1955;96: 387-96.

219. Brachman PS. Inhalational anthrax. Ann NY Acad Sci. 1980;353: 83-93.

220. Armitage HV. Anthrax in delaware county: a historical perspective. Del Med J. 1992;64:331-2.

221. Plotkin SA, Brachman PS, Utell M, Bumford FH, Atchison MM. An epidemic of inhalation anthrax, the first in the twentieth century: I. Clinical features. 1960. Am J Med. 2002;112:4-12.

222. Mayer TA, Bersoff-Matcha S, Murphy C, Earls J, Harper S, Pauze D. Clinical presentation of inhalational anthrax following bioterrorism exposure. Report of 2 surviving patients. JAMA. 2001;28: 2549-53.

223. Jernigan DB, Raghunathan PL, Bell BP, Brechner R, Bresnitz EA, Butler JC. Investigation of bioterrorism-related Anthrax, United States, 2001: epidemiological findings. Emerg Inf Dis. 2002;8: 1019-28.

224. Dewan PK, Fry AM, Laserson K, Tierney BC, Quinn CP, Hayslett JA,. Anthrax response team. Inhalational anthrax outbreak among postal workers, Washington, DC, 2001. Emerg Infect Dis. 2002;8: 1066-72.

225. Berdjis CC, Gochenour S, Jr, Henderson JE. Modification of anthrax by ionizing radiation. J Infect Dis. 1963;113:219-27.

226. Gray I. Lysine deficiency and host resistance to anthrax. J Exp Med. 1963;117:497-508.

227. Guillemin J. Anthrax: the investigation of a deadly outbreak. Berkeley, Los Angeles, London: University of California Press; 1999.

228. ProMED-mail. Anthrax, virulence. Published Date: 2003-04-07 23:50:00. Subject: PRO> Anthrax, virulence. Archive Number: 20030407.0849. Last accessed 31 August 2018.

229. Barnes M, Riley JM, Wolfe VL. Change in virulence of Bacillus anthracis spores as affected by solids and challenge routes. J Infect Dis. 1963;112:187-93.

230. Baillie L. Immune response of naturally infected individuals. Anthrax counter measures 2013 international conference proceedings, Royal United Services Institute, London 4 February 2013. Mil Med Sci Lett (Voj Zdrav Listy). 2013;82:73.

231. Dahlgren VM, Buchanan LM, Decker HM, Freed SW, Phillips CR, Brachman PS. Bacillus anthracis aerosols in goat hair processing mills. Am J Hyg. 1960;72:24-31.

232. Kissling E, Wattiau P, China B. B. anthracis in a wool-processing factory: seroprevalence and occupational risk. Epidemiol Infect. 2011;140:879-86.

233. Friedlander AM, Pittman PR, Parker GW. Anthrax vaccine: evidence for safety and efficacy against inhation anthrax. JAMA. 1999;282:2104-6.

234. Anaraki S, Addiman S, Nixon G, Krahé D, Ghosh R, Brooks T, Lloyd G, Spencer R, Walsh A, McCloskey B, Lightfoot N. Investigations and control measures following a case of inhalation anthrax in East London in a drum maker and drummer. October 2008. Euro Surveill. 2008;13:51.

235. Jamieson WH, Green DM. Anthrax and bone-meal fertiliser. Lancet. 1955;268:560.

236. Davies L. Anthrax - A health hazard at the bottom of the garden? Community Health. 1972;3:271-2.

237. Raber E, Carlsen T, Kirvel R. Remediation following chemical and biological attacks. In: Maurer SM, editor. WMD terrorism: science and policy choices. Cambridge, MA: The MIT Press; 2009. p. 365-88.

238. Wilson JM, Brediger W, Albright TP, Smith-Gagen J. Reanalysis of the anthrax epidemic in Rhodesia, 1978-1984. Peer J. 2016;4: e2686.

239. Vasan SS. Anthrax counter measures. In: Anthrax counter measures 2013 International conference proceedings, Royal United Services Institute, London 4 February 2013. Mil Med Sci Lett (Voj Zdrav Listy). 2013;82:70-1.

240. Silman N, Sweed A, Bell E, Ezzi M, Neal D. A simple, portable biosensor system to detect anthrax in soil and environmental samples within 17 minutes. In: Anthrax counter measures 2013 international conference proceedings, Royal United Services Institute, London 4 February 2013. Mil Med Sci Lett (Voj Zdrav Listy). 2013;82:83.

241. Winkle S. Milzbrand (Anthrax). In: Winkle S, editor. Geißeln der Menschheit. Kulturgeschichte der Seuchen. Third improved and expanded edition. Düsseldorf: $\odot 1997$ Patmos Verlag GmbH \& Co. KG Artemis \& Winkler Verlag; 2005. p. 47-82. 
242. The Medical and Surgical History of the War of the Rebellion. Part III, Vol. I, Washington; 1888. p. 11.

243. Fontaine H. 2. Milzbrand und Tollwut. In: Das Deutsche Heeresveterinärwesen. Seine Geschichte bis zum Jahre 1933. Hrsg. und editiert im Auftrage des Veterinärinspekteurs im Oberkommando des Heeres. Hannover: Verlag von M. \& H. Schaper; 1939. p. 475.

244. Nitsche E. 2. Milzbrand und Tollwut. 5. Kapitel. Die Seuchenbekämpfung. In: Fontaine H, editor. Das Deutsche Heeresveterinärwesen. Seine Geschichte bis zum Jahre 1933. Hrsg. und editiert im Auftrage des Veterinärinspekteurs im Oberkommando des Heeres. Hannover: Verlag von M. \& H. Schaper; 1939. p, 454-73.

245. KB Kriegsarchiv 4. Division IV.J.1 - V.A.6.g. 8 Akten No. 57, Bayerisches Kriegsarchiv, München.

246. Beiheft zum Militär-Wochenblatt 1877: Bayer, Hauptstaatsarchiv Abt. IV Kriegsarchiv 11. München. 1877 p. 37 and following ones.

247. Statistischer Sanitätsbericht über die königlich preußische Armee und das XIII. (königlich württembergische) Armeekorps für die Jahre 1870, 1871, 1872 und das erste Vierteljahr 1873, ausschließlich des Kriegsjahres 1870/71. Bearbeitet von MilitairMedizinalabtheilung des königlich preußischen Kriegministeriums. C. G. Mittler und Sohn Berlin; 1876.

248. Sanitäts-Bericht über die Deutschen Heere im Kriege gegen Frankreich 1870/71. Militär-Medizinal-Abtheilung des Königlich Preussischen Kriegsministeriums (Hrsg.). Zweiter Band. II. Statistischer Theil: Morbidität und Mortalität bei den Deutschen Heeren und bei den in Deutschland untergebrachten kriegsgefangenen Franzosen. E. S. Mittler und Sohn Berlin; 1886.

249. Hirschberg R. Die bayerischen Spitalzüge im deutschfranzösischen Krieg 1870/71. München: Theodor Ackermann; 1872.

250. Jungblut. Betrachtungen über Kriegsverluste durch Waffen und Krankheiten. Der deutsche Militärarzt. 1936;1:49-52.

251. Sanitäts-Bericht über die Deutschen Heere im Kriege gegen Frankreich 1870/71. Militär-Medizinal-Abtheilung des Königlich Preussischen Kriegsministeriums, editor. Dritter Band. Allgemeiner Theil. III. Chirurgischer Theil: A. Verwundungen (Allgemeines). E.S. Mittler und Sohn Berlin; 1890.

252. Sanitäts-Bericht über die Deutschen Heere im Krieg gegen Frankreich 1870/71. Medizinal-Abtheilung des Königlich-Preussischen Kriegsministeriums unter Mitwirkung der MilitärMedizinal-Abtheilung des Königlich Bayerischen Kriegsministeriums, der Königlich Sächsischen Sanitätsdirektion und der Militär-Medizinal-Abtheilung des Königlich Württembergischen Kriegsministeriums (Hrsg.). Achter Band. Register, LiteraturVerzeichniss. E. S. Mittler und Sohn Berlin; 1891.

253. Köhler A. Die Kriegschirurgen und Feldärzte Preussens und anderer deutscher Staaten in Zeit- und Lebensbildern. In: Köhler A, editor. Veröffentlichungen aus dem Gebiet des MilitärSanitätswesens. Hrsg. Medizinal-Abteilung des Königlich Preussischen Kriegsministeriums. Heft 27, IV. Teil. Kriegschirurgen und Feldärzte der Neuzeit. Berlin: Verlag von August Hirschwald; 1904.

254. Koch R. Untersuchungen über Bacterien. Die Aetiologie der Milzbrand-Krankheit, begründet auf die Entwicklungsgeschichte des Bacillus anthracis. Beitr z Biol d Pflanz. 1876;2:277-308.

255. Taubitz D. Seuchenstatistik und Epidemiologie in den deutschen Heeren im 19. Jahrhundert. In: Fontaine H. 2. Milzbrand und
Tollwut. In: Das Deutsche Heeresveterinärwesen. Seine Geschichte bis zum Jahre 1933. Hrsg. und editiert im Auftrage des Veterinärinspekteurs im Oberkommando des Heeres. Hannover: Verlag von M. \& H. Schaper; 1939. p. 475.

256. Meißner B. Deutsch-Südwestafrika. In: Fontaine H. 2. Milzbrand und Tollwut. In: Das Deutsche Heeresveterinärwesen. Seine Geschichte bis zum Jahre 1933. Hrsg. und editiert im Auftrage des Veterinärinspekteurs im Oberkommando des Heeres. Hannover: Verlag von M. \& H. Schaper; 1939. p. 476-7.

257. Gärtner WD. Deutsch-Ostafrika. In: Fontaine H. 2. Milzbrand und Tollwut. In: Das Deutsche Heeresveterinärwesen. Seine Geschichte bis zum Jahre 1933. Hrsg. und editiert im Auftrage des Veterinärinspekteurs im Oberkommando des Heeres. Hannover: Verlag von M. \& H. Schaper; 1939. p. 815-6.

258. Palutke I. Centralblatt für Bakteriologie, Parasitenkunde und Infektionskrankheiten von 1903 bis 1914 - Spiegelbild der Wechselbeziehungen von Bakteriologie und Militärmedizin im Vorfeld des 1. Weltkriegs. Dipl. Arbeit MMS Greifswald; 1988.

259. Ak F 58-2522 Fachbibliothek Sanitätsakademie der Bundeswehr. Die Theorie und Praxis der Behandlung der Infektionskrankheiten im Kaiserlichen Deutschen Heer Ausgang des 19./Beginn des 20. Jahrhunderts: Eine Analyse anhand der "Deutschen Militärärztlichen Zeitschrift", 2014.

260. His W, Weintraud W, editors. Kriegsseuchen und Kriegskrankheiten; Verhandlungen der ausserordentlichen Tagung des Deutschen Kongresses für Innere Medizin in Warschau am 1. und 2. Mai 1916. Wiesbaden: Verlag von JF Bergmann; 1916.

261. Zieger W. Das deutsche Heeresveterinärwesen im Zweiten Weltkrieg. 1. Aufl. Militärgeschichtliches Forschungsamt, editor. Freiburg: Verlag Rombach + Co GmbH; 1973. p. 332-8.

262. Kriegsveterinärbericht des deutschen Heeres 1914-1918. Reichswehrministerium (Hrsg.). Berlin: gedruckt im Reichswehrministerium; 1929.

263. Müller H. Die ansteckenden Krankheiten im deutschen Heer während der ersten vier Kriegsjahre. 1. September 1939 bis 31. August 1943. Bearbeitet nach den zehntägigen Truppenkrankennachweisen. Wehrmed Mitt. 1961:4:22-7.

264. Kulicke G. Unser Heeressanitätswesen mit Rückschluß über die Verluste der Kriegsheere im Weltkrieg 1914/1918. Frankfurt am Main; 1953.

265. Sanitätsbericht über das deutsche Heer (Deutsches Feld- und Besatzungsheer) im Weltkriege 1914/18 (Deutscher Kriegssanitätsbericht 1914/18). Bearbeitet in der Heeres-Sanitätsinspektion des Reichswehrministeriums. Band III, Die Krankenbewegung bei dem deutschen Feld- und Besatzungsheer. 5. Milzbrand. Andere übertragbare und allgemeine Erkrankungen (Rapp. Nr. 14). Berlin: E.G. Mittler \& Sohn; 1934. p. 141.

266. Läwen A, Schöne G, Kehl H. III. Wundinfektion, Verhütung und Behandlung. In: Payr E, Franz C, editors. Band I-Chirurgie- Erster Teil: In: von Schjerning O, editor. Handbuch der ärztlichen Erfahrungen im Weltkriege 1914/1918. Leipzig: Verlag Johann Ambrosius Barth; 1922. p. 100-1.

267. Klose F. Über Toxin- und Antitoxinversuche mit dem Fraenkelschen Gasbrandbazillus. Feldärztliche Beiträge. Münch Med Wschr. 1916;20;723-6.

268. Klose F. Gasödem. In: Hofmann W, editor. Band VII. Hygiene. In: von Schjerning O, editor. Handbuch der ärztlichen Erfahrungen 
im Weltkriege 1914/1918. Leipzig: Verlag Johann Ambrosius Barth; 1922. p. 574-88.

269. Klose F. Bakteriologisch-serologische Grundlagen zur Frage der Herstellung eines Gasbrandserums. In: Klose F, editor. Untersuchungen über den Serumschutz bei Gasödem. In: Veröffentlichungen aus dem Gebiet des Militär-Sanitätswesens. H. 68; Sanitäts-Department, Königlich Preußisches Kriegsministerium (Hrsg.). Berlin; 1918. p. 17-34.

270. Klose F. Ein Beitrag zur Kenntnis der durch die Gruppe der Gasödem-Bazillen erzeugten anaeroben Wundinfektionen. Feldärztliche Beiträge. Münch Med Wschr. 1917;9:295-6.

271. Thomssen R. Soll bereits bei der Erstversorgung (Erste Hilfe, erste ärztliche Versorgung) von Verletzten und Verwundeten mit der Infektionsprophylaxe durch Antibiotika begonnen werden und unter welchen Voraussetzungen? Wehrmed Mschr. 1973,10: 312-7.

272. Emminger E. Probleme des Gasbrandes. Wehrmed Mitteil. 1963;6: 81-6.

273. Schjerning v O, Krehl v L. Handbuch der Ärztlichen Erfahrungen im Weltkriege 1914/1918.: Band II. Innere Medizin. Leipzig: Verlag v. Johann Ambrosius Barth; 1921.

274. Dopter M. XVI Charbon Bacteridien. In: Les Maladies infectieuses pendant la Guerre. (Etude Epidemiologigue). In: Le Questions actuelle. Etudes de Culture general, publiees sous la direction de Emile Horel \& George Dumas. Librairie Felix Alcane; 1927. p. 284-5.

275. Ireland MW. Chapter V. Anthrax. Statistical considerations. In: Ireland MW, Siler JF, editor. The medical department of the United States army in the world war. Vol. IX Communicable and other diseases. Washington: U.S. Government Printing Office; 1928. p. 223-32.

276. Siler JF. The medical department of the United States army in the world war. (Direction: the Surgeon General MW Ireland): Vol. IX. Communicable and other diseases. Chapter V anthrax. Washington: U.S. Government Printing Office;1928. p. 223-32.

277. Shljachov EN. Epidemiologija, diagnostika I profilaktika sibirskoj jazvy, Kishinjev; 1960.

278. Karaffa-Korbut KV. Bor'ba s infekcionnymi boleznjami v dejstvujushchej armii v usloviajch tekushchej kampanii. Pg: Prakticheskaya medicina; 1917. p. 8. [Russian].

279. Marshall E. Sverdlovsk: anthrax capital? Science. 1988;240:383-5.

280. Smirnov EI, Lebedinskij VA, Garin NS. Vojny i epidemii. AMN SSSR. Moskva: Medicina; 1988. [Russian].

281. Becker H. Krieg in der Türkei 1914-1918 Äskulap zwischen Reichsadler und Halbmond. Sanitätswesen und Seuchenbekämpfung im türkischen Reich während des I. Weltkrieges. Verlag Murken-Altrogge, Herzogenrath 3; 1990.

282. Buchner L. Veterinärdienst im Deutschen Heer während des Ersten Weltkrieges - Entstehung eines Veterinärkorps und erste Bewährungsprobe. Wehrmed Mschr. 2016;60:178-86.

283. Machalett G, Finke EJ. Die medizinische Versorgung der deutschen Militärmission in Vorderasien 1914-1918. Wehrmed Monatsschr. 2015;59:248-58.

284. Greve L. Beobachtung über das Aufrteten des Milzbrandes im Herzogtum Oldenburg und dessen Ursache. Berl Tierärztl Wschr. 1915;12:133-5.

285. Mießner H, Schoop G. Kriegstierseuchen und ihre Bekämpfung. Milzbrand. In: Leitfaden für Veterinäroffiziere, beamtete und praktische Tierärzte, Studierende der Veterinärmedizin. 5. Aufl. Hannover: M. \& H. Schaper; 1941. p. 50-63.

286. Petersen R. "When a nation is being murdered" - The secret biological and chemical war against the Third Reich. Zeszyty Naukowe Akademii Sztuki Wojennej nr 2. 2016;103:158-74.

287. Geissler E. Conversion of BTW facilities: lessons from German history. In: Geissler E, editor. Conversion of former BTW facilities. Dordrecht: Kluwer Academic Publisher; 1998. p. 53-66.

288. Overmanns R. Deutsche militärische Verluste im Zweiten Weltkrieg. (Zugleich phil. Diss., Freiburg/Br. 1996) 3. Aufl. München-Wien: Oldenbourg; 2004.

289. Anonymous. Sanitätsbericht des deutschen Heeres - Verwundeten- und Krankenzahlen aus dem Zweiten Weltkrieg. Wehrmed Mitt. 1960;10:166-8.

290. Fischer H. Der deutsche Sanitätsdienst 1921-1945. Band 4; Teil C: Der Sanitätsdienst der Wehrmacht im 2. Weltkrieg (1939-1945). Osnabrück: Biblio Verlag; 1985.

291. Müller H. Vorläufiger Sanitätsbericht des deutschen Heeres 19391943: Truppenkrankennachweise; Sanitätspersonal. Band 1939/43; Berlin; 1961. p. 24.

292. Zimmer A. Krieg und Krankheit. In: Zimmer A. editor. Wehrmedizin Kriegserfahrungen 1939-1943. III. Band: Innere Medizin und Neurologie. Wien: Franz Deuticke; 1944.

293. Wohlfeil T, Maaß J. Schutzimpfungen in der Wehrmacht, ihre Wirksamkeit, Vorbereitung und Durchführung. Der Deutsche Militärarzt. 1940;5:305-21.

294. Walther G. Die Ergebnisse der Tagung der Beratenden Ärzte am 3. und 4. Januar 1940 in der Militärärztlichen Akademie zu Berlin. Der Deutsche Militärarzt. 1940;5:127-30.

295. Knofloch IG. Über Wundinfektion und Wundbehandlung (Gasbrand, Tetanus). In: Zimmer A, editor. Wehrmedizin Kriegserfahrungen 1939-1943. I. Band: Kriegschirurgie. Wien: Franz Deiticke; 1944. p. 71-99.

296. Otto RB. Allgemeine Ätiologie. In: Handloser S, Hoffmann W, editors. Wehrhygiene. I. Abschn. Infektionskrankheiten. Berlin: Springer Verlag; 1944. p. 1-3.

297. Handloser S. Innere Wehrmedizin. Dresden - Leipzig: Theodor Steinkopff; 1944.

298. Curschmann HD. Prognose der akuten Infektionskrankheiten. Lehrbuch der speziellen Prognostik innerer Krankheiten, Stuttgart: Ferdinand Enke Verlag; 1942. p. 13-60.

299. Schloßberger H. Kriegsseuchen Historischer Überblick über ihr Auftreten und ihre Bekämpfung. Jena: Verlag von Gustav Fischer; 1945.

300. Walther K. 23. Milzbrand. In: Handloser S, Hoffmann W, editors. Wehrhygiene. I. Abschn. Infektionskrankheiten. Berlin: Springer Verlag; 1944.

301. Zeiss HD. Geomedizin und Seuchenbekämpfung. In: Handloser S, Hoffmann W. Wehrhygiene. I. Abschn. Infektionskrankheiten. Berlin: Springer Verlag; 1944.

302. Teller HRB. Hygiene bei den Spezialtruppen. 1. Pioniere. In: Handloser S, Hoffmann W, editors. Wehrhygiene. IX. Abschn. Hygiene des Dienstes. Berlin: Springer Verlag; 1944.

303. Zeiss H, Rodenwaldt E. Einführung in die Hygiene und Seuchenlehre. Stuttgart: Enke; 1942.

304. Hornung H. Gesundheitsvorsorge durch die Deutsche Wehrmacht in der Bevölkerung der besetzten Gebiete. Manuskript 1945, 
Fachbibliothek Sanitätsakademie der Bundeswehr, München. Nr. 2150 .

305. Finger G. Erfahrungen des Sanitäts- und Gesundheitsdienstes beim Einsatz deutscher Truppen in tropischen und subtropischen Gebieten während des Zweiten Weltkrieges. Wehrdienst und Gesundheit, Bd. I. Darmstadt: Wehr und Wissen; 1959. p. 253-62.

306. Höring FO. Infektionskrankheiten im Kriege. Wehrmed Mitteil. 1960;3:33-7.

307. Walther K. Seuchenvorkommen und Seuchenbekämpfung in Südrußland. In: Fischer H, editor. Der Deutsche Sanitätsdienst 1921-1945. Bd. 3, Teil C: Der Sanitätsdienst der Wehrmacht im 2. Weltkrieg (1939-1945). Osnabrück: Biblio Verlag; 1984.

308. Stickl HA. Der Einfluß von Seuchen auf den Verlauf von Kriegen und Katastrophen (Teil I). Wehrmed Mschr. 1985;29:222-4.

309. Stickl HA. Der Einfluß von Seuchen auf den Verlauf von Kriegen und Katastrophen (Teil II). Wehrmed Mschr. 1985;6:268-73.

310. Ebel R. Die Entwicklung der Hygiene des Wehrdienstes in Deutschland seit dem 19. Jahrhundert. (Teil I). Wehrmed Mschr. 1988;32:329-36.

311. Fischer H. Der deutsche Sanitätsdienst 1921-1945. Band 3; Teil C: Der Sanitätsdienst der Wehrmacht im 2. Weltkrieg (1939-1945). 6. Bericht über den amerikanischen Sanitätsdienst. Osnabrück: Biblio Verlag; 1984. p. 1800-13.

312. Fischer H. Der deutsche Sanitätsdienst 1921-1945. Band 3; Teil C: Der Sanitätsdienst der Wehrmacht im 2. Weltkrieg (1939-1945).

7. Bericht über den britischen Sanitätsdienst. Osnabrück: Biblio Verlag; 1984. p. 1814-5.

313. Barykin V, Vygodchikov G, Sazhina Y. Outbreak of intestinal anthrax in Yaroslavl. Zh Gigiyena Epidemiol. 1929;1:25-30. [Russian].

314. Viskovskiy CV; Rozhdestvenskiy VM. Osnovnye principy protivoepidemicheskoy raboty sredi naseleniya $\mathrm{i}$ v voyskach $\mathrm{V}$ period Velikoy otechestvennoy voyny. Razdel Vtoroy. In: Tom 32 Epidemiologiya. In: Opyt sovjetskoy mediciny v Velikoy otechestvennoy voyne 1941-1945 gg. Moskva: 1955. p. 77-85. [Russian].

315. F. Wehrmedizinische Erfahrungen. Beherrschung der Infektionen von Kriegswunden. Wehrmed Mitteil. 1960;4:62-3.

316. Fischer H. Die sanitätsdienstliche, wehrmedizinische und kriegschirurgische Betreuung und Behandlung der UN-Truppen im Korea-Konflikt. Wehrmed Mitteil. 1963;6:149-51.

317. Wehrmedizinische Erfahrungen. Ärztliche Erfahrungen im Koreakrieg (V). Wehrmed Mitteil. 1963;4:109-11.

318. Matsumoto T, Hardaway RM, Dobek AS, Noyes HE. Different soils in simulated combat wounds: I. Vietnam. Mil Med. 1967;132: 893-5.

319. Matsumoto T, Wyte SR, Moseley RV, Hawley RJ, Lackey RL. Combat surgery in communication zone. I. War wound and bacteriology (preliminary report). Mil Med. 1969;134:655-5.

320. Allen MA, Taplin D, Lowy JA, Twigg L. Skin infections in Vietnam. Mil Med. 1972;137:295-301.

321. Kapp JP. An analysis of infections in neurosurgical wounds sustained in Vietnam. Mil Med. 1977;142:763-6.

322. Palinkas LA, Coben P. Disease and non-battle injuries among U.S. Marines in Vietnam. Mil Med. 1988;153:150-5.

323. Washington M, Brown M, Palys T, Tyner S, Bowden R. Clinical microbiology during the Vietnam War. Mil Med. 2009;174:1209-14.
324. Hardaway RM. Vietnam wound analysis. J Trauma. 1978;18: 653-43.

325. Tinder LE, Osborn DB, Lilly GE. Maxillofacial injuries sustained in the Vietnam conflict. Milit Med. 1969;134:668-72.

326. Kovaric JJ, Matsumoto T, Dobek AS, Hamit HF. Bacterial flora of one hundred and twelve wounds. Milit Med. 1968;133:622-4.

327. Tong MJ. Septic complications of war wounds. JAMA. 1972;219: 1044-7.

328. Jacob E, Setterstrom JA. Infection in war wounds: Experience in recent military conflicts and future considerations. Mil Med. 1989; 154:311-5.

329. Simchen E, Sachs T. Infection in war wounds: experience during the 1973 October War in Israel. Am Surg. 1975;182:754-61.

330. Rappert B, Gould C. The dis-eases of secrecy tracing history, memory \& justice. Jacana Media (Pty) Ltd. 2017, p. 260.

331. Davies JC. A major epidemic of anthrax in Zimbabwe. Cent Afr J Med (Zimbabwe). Part 1. 1982;28:291-8, Part 2. 1983;29:8-12, Part 3. 1985;31:176-80.

332. Lovric Z. Letter from Croatia. Surgical management of casualties in a low intensity war. Nat Med J India. 2002;15:111-3.

333. Korzeniewski K, Pieniuta S, Gregulski R. Battle injuries in Polish soldiers employed to ISAF operation in Afghanistan. Intern Rev Armed Forces Med Serv. 2015;88:5-12.

334. Vehmeier W. Internistische Erkrankungen in der Tropenmedizin (akute Infektionen nach kurzer Exposition und kurzer Inkubation). Kurzfassung d. Vortrags V-173. 31. Kongress der DGWMP, Ulm 5.-8.10.2000. Wehrmed Mschr. 2000;44(Supl.):36.

335. Zöller L. Infektionskrankheiten im Einsatz - Meta-Analyse epidemiologischer Daten aus internationalen Einsätzen. Kurzfassung d. Vortrags V-172. 31. Kongress der DGWMP, Ulm 5.-8.10.2000. Wehrmed Mschr. 2000;44(Supl.):35-6.

336. Zouris JM, Wade AL, Magno CP. Injury and illness casualty distribution among U.S Army and marine corps personnel during operation Iraqi freedom. Mil Med. 2008;173:247-52.

337. Murray CK, Roop SA, Hospenthal DR, Dooley DP, Wenner K, Hammock J, Taufen N, Gourdine E. Bacteriology of war wounds at the time of injury. Mil Med. 2006;171:826-9.

338. Yun HC, Murray CK, Roop SA, Hospenthal DR, Gourdine E, Dooley DP. Bacteria recovered from patients admitted to a deployed U.S. military hospital in Baghdad, Iraq. Mil Med. 2009; 171:821-5.

339. Sinnecker H. Allgemeine epidemiologie. Jena: VEB Gustav Fischer Verlag; 1971.

340. Robert Koch Institut. 6.39 Milzbrand. In: Infektionsepidemiologisches Jahrbuch meldepflichtiger Krankheiten für 2018. Datenstand 1 März 2019. Berlin: Robert Koch Institut; 182.

341. Upravlenie Medicinskoj sluzhby Vengerskoj Narodnoj Armii. Reg. No 070/70/1983: Prirodnye ochagi infekcionnych bolezneij na evropeiskoj chasti territorii SSSR (SSSR) Sibirskaya jazva. Tema IV.10 "Ochagi antroponoza" "plana nauchno-issledovatel'skich rabot 1970-1988. Pers. Archiv Finke EJ. [Russian].

342. Frickmann H, Hagen RM, Geiselbrechtinger F, Hoysal N. Infectious diseases during the European Union training mission Mali (EUTM MLI) - a four-year experience. Mil Med Res. 2018;315:19.

343. Lübken von F, Achatz G, Friemert B, Mauser M, Franke A, Kollig E, Bieler U. Update zu Schussverletzungen der Extremitäten. Wehrmed Mschr. 2018;62:191-8. 
344. Nippen M. Warum haben wir Tierärzte in der Bundeswehr? Wehrmed Mschr. 2017;61:324-5.

345. Turnbull PCB, Hutson RA, Ward MJ, Jones MN, Quinn CP, Finnie NJ, Duggleby CJ, Kramer JM, Melling J. Bacillus anthracis but not always anthrax. J Appl Bacteriol. 1992;72:21-48.

346. Turnbull PCB, Lindeque PM, Le Roux J, Bennett AM, Parks SR. Airborne movement of anthrax spores from carcass sites in Etosha National Park, Namibia. J Apl Microbiol. 1998;84:667-76.

347. Coker PR, Smith KL, Fellows PF, Rybachuck G, Kousoulas KG, Hugh-Jones ME. Bacillus anthracis virulence in guinea pigs vaccinated with anthrax vaccine adsorbed is linked to plasmid quantities and clonality. J Clin Microbiol. 2003;41:1212-8.

348. Hugh-Jones M. Comment in: ProMED-mail: Published Date: 2019-07-17 16:56:59. Subject: PRO/AH/EDR> Anthrax Kazakhstan: (TK) cattle graves, still safe. Archive Number: 20190717.6573796. Date: Wed 17 Jul 2019. Source: Kazakh Telegraph Agency [edited] https://kaztag.kz/en/news/no-threat-ofanthrax-in-arys-officials, Last accessed 19 July 2019.

349. Cherkasskiy BL. The epidemiology, epizootiology and prevention of anthrax in the former USSR. Zh Mikobiol Epidemiol Immunobiol. 2010;4;23-6. [Russian].

350. Kupplich Y. Funktion und Leistungen der Beratenden Internisten im Heeresssanitätsdienst der deutschen Wehrmacht 1939-1945. Dissertation, Universität Leipzig; 1996. p. 1-108.

351. Huxsoll DL. The impact of zoonoses on military operations. In: Topic 2 : Zoonoses in wartime. Presentations at the 27 th International Congress of Military Medicine and Pharmacy. General Secretariat, CIMP; Liege. 1988;1206:1-11.

352. Walsh MG, de Smalen AW, Mor SM. Climatic influence on anthrax suitability in warming northern latitudes. Sci Rep. 2018;8:9269.

353. Brachman PS, Kaufmann AF, Dalldorf FG. Industrial inhalation anthrax. Bacteriol Rev. 1966;30:646-57.

354. Carter T. The dissemination of anthrax from imported wool: Kidderminster 1900-14. Occup Environ Med. 2004;61:103-7.

355. Fowler RA, Shfazand S. Anthrax bioterrorism: prevention, diagnosis and management strategies. J Bioterr Biodef. 2011;2:2.

356. Matthes M. VIII. Erkrankungen des Darmes, der Leber und des Peritoneums. In: B. Besonderer Teil. 1. Infektionskrankheiten. In: Krehl v L (Hrsg.): Innere Medizin. In: Schjerning v O (Hrsg.). Handbuch der Ärztlichen Erfahrungen im Weltkriege 1914/1918. Band III. Leipzig; Verlag Johann Ambrosius Barth: 1921. p. 521-2.

357. Knudson GB. Treatment of anthrax in man: History and current concepts. Mil Med. 1986;151:71-7.
358. Winter H, Pfisterer RM. Inhalationsanthrax bei einem Textilarbeiter: Ein nicht-letaler Verlauf. Schweiz Med Wschr. 1991;121: 832-5.

359. Dernovaja VF, Meka-Mechenko TV, Nekrasova LE, Stepanov VM, Bezrukova LS. Epidmiologicheskoe znachenie nekotorych zoonozov. In: Materialy nauchno-prakticheskoj konferencii, posvjashchennoj 100-letiju obrazovanija portivochumnoj sluzhby Rossii. V dvuch tomach. Tom 1, Rossijskij nauchno-issledovatel'skij protivchumnyj institut "Mikrob", Saratov. 1997. p. 36-7. [Russian].

360. Update: considerations for distinguishing influenza-like illness from inhalational anthrax. MMWR. 2001;50:984-6.

361. Suchard JR. Diagnosis and treatment of cutaneous anthrax. JAMA. 2002;288:43.

362. Friedlander AM. To the Editor. JAMA. 2002;288:43-4.

363. Freedman A, Afonja O, Chang MW. Cutaneous anthrax associated with microangiopathic hemolytic anemia and coagulopathy in a 7-month-old infant. JAMA. 2002;287:869-74.

364. Ghenghesh KS, Rezgalla T, E-Tobgi R. Anthrax. A review. Jamahiriya Med J. 2002;2:17-23.

365. Borkowsky W, Chang MW. In Reply. JAMA. 2002;288:44-5.

366. Niedrig M, Reinhardt B, Burchard G-D, Schmitz H, Tannich E, Tintelnot K. 4.16 Milzbrand (Anthrax). Steckbriefe seltener und importierter Infektionskrankheiten. Berlin: Robert Koch Institut; 2006. p. $80-1$.

367. Bernard H, Faber M, Grunow R, Bochat V, Görg A. Bacillus anthracis in Heroin? Dtsch Ärztebl. 2010;107:C691.

368. Cuthbertson H, Osborne J, Hallis B, Brooks T. Novel methods support diagnosis of anthrax infection in heroin users during UK outbreak. In: Anthrax Counter Measures 2013 International Conference Proceedings, Royal United Services Institute, London 4 February 2013. Mil Med Sci. Lett (Voj Zdrav Listy.). 2013;82:78.

369. Grass G, Wölfel R. Kombinierte molekularbiologische und kulturelle Untersuchung von Heroinproben auf potentielle Kontaminationen mit Bacillus-anthracis-Sporen. Jahrestätigkeitsbericht 2015. Institut für Mikrobiologie der Bundeswehr. Archiv Fachmedienzentrum, Sanitätsakademie der Bundeswehr, München; 2015. p. 44.

370. ProMED-mail. Published Date: 2018-09-25 17:10:28. Subject: PRO/ AH/EDR > Anthrax - Turkey (08): economic background. Archive Number: 20180925.6051600. Source: Ahval [edited] https:// ahvalnews.com/anthrax/problem-bigger-anthrax, Last accessed 26 September 2018. 